\title{
Stereocontrolled Synthesis of Onchidins
}

\author{
Yungui Peng ${ }^{a}$ Heung Wing Pang ${ }^{a}$ and Tao $\mathrm{Ye}^{\star a, b}$ \\ ${ }^{a}$ Department of Chemistry, The University of Hong Kong, Pokfulam Road, Hong Kong; \\ ${ }^{b}$ Open Laboratory of Chirotechnology of the Institute of Molecular Technology for Drug \\ Discovery \& Synthesis and Department of Applied Biology \& Chemical Technology, The \\ Hong Kong Polytechnic University, Hung Hom, Kowloon, Hong Kong, China
}

bctaoye@inet.polyu.edu.hk

E-mail: bctaoye@inet.polyu.edu.hk

\section{GENERAL EXPERIMENTAL}

All non-aqueous reactions were run under an inert atmosphere (nitrogen or argon) with rigid exclusion of moisture from reagents and all reaction vessels were oven-dried. Solvents were distilled prior to use: THF from $\mathrm{Na} /$ benzophenone, dichloromethane, DMF, triethylamine and diisopropylethylamine from $\mathrm{CaH}_{2}$. $\mathrm{NMR}$ spectra were recorded on Bruker Advance DPX 300MHz, AV400MHz or AV600MHz spectrometers. Chemical shifts are reported in parts per million (ppm), relative to either a tetramethylsilane internal standard or the signals due to the solvent. Data are reported as follows: chemical shift, multiplicity $(s=$ singlet, $d=$ doublet, $t=$ triplet, $q=$ quartet, $\mathrm{br}=$ broad), integration, and coupling constants. Low- and high- resolution EI and FAB mass spectra were obtained using a Finnigan MAT 95 mass spectrometer. IR spectra were recorded neatly or as $\mathrm{KBr}$ disk on a Bio-Red FTS 165 Fourier Transform Spectrophotometer. Optical rotations were recorded on a Perkin Elmer 343 Polarimeter. TLC was carried out using pre-coated sheets (Merck silica gel 60- $\mathrm{F}_{250}, 0.2 \mathrm{~mm}$ ) which, after development, were visualized at $254 \mathrm{~nm}$, and/or staining in p-anisole, ninhydrin or phosphomolybdic acid solution followed by heating. Flash column chromatography was performed using the indicated solvents (with $\mathrm{R}_{\mathrm{f}}$ $=1.5-2.0$ for the desired component) on E. Merck silica gel 60 (230-400 mesh ASTM). Melting points were measured on Carl Zeiss melting point apparatus and are uncorrected.

\section{Experimental procedures}

\section{Compound (4)}<smiles>CC(=O)N[C@@H](CCCCOC(C)=O)C(=O)O</smiles>

Freshly distilled benzaldehyde $(2.9 \mathrm{~mL}, 28.5 \mathrm{mmol})$ was added to a solution of L-lysine monohydrochloride $(5 \mathrm{~g}, 27 \mathrm{mmol})$ in $2 \mathrm{~N}$ lithium hydroxide solution $(14 \mathrm{~mL})$ at $0^{\circ} \mathrm{C}$. The reaction flask was shaken until the 
benzaldehyde had dissolved and a white solid precipitated. After standing in the refrigerator for several hours, the solid was filtered, washed with cold ethanol and dried over phosphorus pentoxide for one day to give $\mathrm{N}^{\varepsilon}$-benzylidene-L-lysine $(4.78 \mathrm{~g}, 75 \%)$ as a white solid, which was used in the next step without purification.

$\mathrm{N}^{\varepsilon}$-benzylidene-L-lysine $(4.78 \mathrm{~g}, 20 \mathrm{mmol})$ was dissolved in a mixture of $1 \mathrm{~N}$ sodium hydroxide solution $(20 \mathrm{~mL})$ and ethanol $(20 \mathrm{~mL})$ below $-5^{\circ} \mathrm{C}$. A cooled mixture of $1 \mathrm{~N}$ sodium hydroxide solution and ethanol $(1: 1,80 \mathrm{~mL})$ and benzyl chloroformate $(3.9 \mathrm{~mL}, 26 \mathrm{mmol})$ were added in two portions over 5 to $6 \mathrm{~min}$ at $-10^{\circ} \mathrm{C}$ with vigorous stirring. The mixture was stirred at the same temperature for $10 \mathrm{~min}$ and then room temperature for a further $10 \mathrm{~min}$. Conc. hydrochloric acid $(6 \mathrm{~mL})$ was added and the resulting mixture was heated at $50^{\circ} \mathrm{C}$ for $10 \mathrm{~min}$. The mixture was then extracted with diethyl ether $(2 \times 50 \mathrm{~mL})$ and the aqueous layer was adjusted to $\mathrm{pH}$ 6.2. The resulting mixture was concentrated in vacuo to a volume of approximately 50 to $60 \mathrm{~mL}$. After standing in the refrigerator for 2 days, the white crystals were filtered off, washed with a small amount of cold water and dried over phosphorus pentoxide for one day to give $\mathrm{N}^{\alpha}$-carbobenzoxy-L-lysine $(3.36 \mathrm{~g}, 60 \%)$ as a white solid, which was used in next step without purification.

Sodium nitrite $(2.8 \mathrm{~g}, 40.1 \mathrm{mmol})$ was added in three portions over $20 \mathrm{~min}$ to a stirred mixture of $\mathrm{N}^{\alpha}$-carbobenzoxy-L-lysine $(3.5 \mathrm{~g}, 12.5 \mathrm{mmol})$ and sodium acetate $(1.1 \mathrm{~g}, 13.6$ mmol) in acetic acid $(90 \mathrm{~mL})$ at $40^{\circ} \mathrm{C}$. The resulting mixture was stirred at the same temperature for $6 \mathrm{~h}$. The solvent was removed in vacuo as far as possible. Water $(100 \mathrm{~mL})$ was added to the resulting residue and the mixture was extracted by dichloromethane $(3 \times 100 \mathrm{~mL})$. The combined organic extracts were dried $\left(\mathrm{Na}_{2} \mathrm{SO}_{4}\right)$ and concentrated in vacuo to give crude $\operatorname{acid}(2.4 \mathrm{~g}, 60 \%)$ as a pale yellow oil. The acid was used in the next reaction without further purification; ${ }^{1} \mathrm{H}$ NMR $\left(400 \mathrm{MHz}, \mathrm{CDCl}_{3}\right) \delta 1.39-1.50(\mathrm{~m}, 2 \mathrm{H}), 1.59-1.76(\mathrm{~m}, 3 \mathrm{H}), 1.86-$ $1.98(\mathrm{~m}, 1 \mathrm{H}), 2.03(\mathrm{~s}, 3 \mathrm{H}), 4.05(\mathrm{t}, \mathrm{J}=6.5 \mathrm{~Hz}, 2 \mathrm{H}), 4.36-4.41(\mathrm{~m}, 1 \mathrm{H}), 5.11(\mathrm{~s}, 2 \mathrm{H}), 5.49(\mathrm{~d}$, $\mathrm{J}=8.1 \mathrm{~Hz}, 1 \mathrm{H}), 7.29-7.35(\mathrm{~m}, 5 \mathrm{H})$. 


\section{Compound (5)}<smiles>CC(=O)N[C@@H](CCCCOC(C)=O)C(=O)C=[W]</smiles>

Triethylamine $(3.8 \mathrm{~mL}, 27 \mathrm{mmol})$ and isobutyl chloroformate $(3.7$ $\mathrm{mL})$ were added to a stirred solution of acid (4) $(8.72 \mathrm{~g}, 27 \mathrm{mmol})$ in dry THF $(135 \mathrm{~mL})$ at $-25^{\circ} \mathrm{C}$ and under an atmosphere of argon.

The resulting mixture was stirred at the same temperature for $30 \mathrm{~min}$ then at $-10^{\circ} \mathrm{C}$ for $30 \mathrm{~min}$. The mixture was then added dropwise to a stirred solution of diazomethane ${ }^{111}$ in diethyl ether at $-10^{\circ} \mathrm{C}$ and under an atmosphere of argon. The resulting mixture was stirred for $1 \mathrm{~h}$ then allowed to warm to room temperature and stirred overnight. Excess diazomethane was destroyed by blowing air in the reaction flask for $1 \mathrm{~h}$. The volatile solvents were removed in vacuo and the residue was dissolved in ethyl acetate $(500 \mathrm{~mL})$ and washed with saturated $\mathrm{NaHCO}_{3}$ solution $(50 \mathrm{~mL})$, saturated $\mathrm{NaCl}$ solution $(50 \mathrm{~mL})$, dried $\left(\mathrm{Na}_{2} \mathrm{SO}_{4}\right)$ and evaporated in vacuo to leave an pale yellow oil. The oil was purified by silica gel chromatography using $15 \%$ ethyl acetate - hexane as eluent to give the diazoketone $(6.56 \mathrm{~g}, 70 \%)$ as a pale yellow oil; IR (neat) $v_{\max } 3326,3092,3033,2954,2868,2107,1748,1714,1637,1520,1455,1361$, 1243, 1150, 1044, 909, 847, 753, 698 and $666 \mathrm{~cm}^{-1} ;[\alpha]_{\mathrm{D}}{ }^{20}-15.6\left(\mathrm{c}=1.52, \mathrm{CHCl}_{3}\right)$; HRMS(EI) for maximum ion $\mathrm{C}_{17} \mathrm{H}_{21} \mathrm{NO}_{5}$ (Loss $\mathrm{N}_{2}$ ): Calcd 319.1420; Found 319.1410; ${ }^{1} \mathrm{H}$ NMR (400 $\left.\mathrm{MHz}, \mathrm{CDCl}_{3}\right) \delta 1.37-1.44(\mathrm{~m}, 2 \mathrm{H}), 1.56-1.68(\mathrm{~m}, 3 \mathrm{H}), 1.82-1.87(\mathrm{~m}, 1 \mathrm{H}), 2.04(\mathrm{~s}, 3 \mathrm{H})$, $4.04(\mathrm{t}, \mathrm{J}=6.5 \mathrm{~Hz}, 2 \mathrm{H}), 4.24(\mathrm{~m}, 1 \mathrm{H}), 5.10(\mathrm{~s}, 2 \mathrm{H}), 5.44(\mathrm{~s}, 1 \mathrm{H}), 5.49(\mathrm{~d}, \mathrm{~J}=7.8 \mathrm{~Hz}, 1 \mathrm{H})$, $7.31-7.36(\mathrm{~m}, 5 \mathrm{H}) ;{ }^{13} \mathrm{C} \mathrm{NMR}\left(100 \mathrm{MHz}, \mathrm{CDCl}_{3}\right) \delta 20.89,21.64,28.21,32.06,54.06,57.54$, $63.86,67.01,128.03,128.19,128.49,136.11,155.91,171.08,193.11$.

\section{Compound (6)}

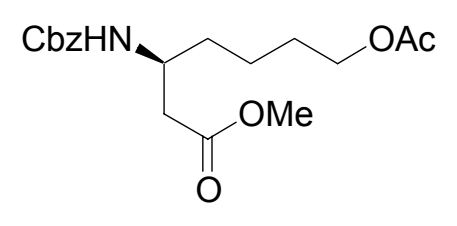

Silver benzoate $(85.4 \mathrm{mg}, 0.37 \mathrm{mmol})$, dissolved in triethylamine (1.38 mL, $9.8 \mathrm{mmol})$, was added to a stirred solution of diazoketone (5) $(1.18 \mathrm{~g}, 3.4 \mathrm{mmol})$ in dry methanol $(15 \mathrm{~mL})$ at $-25^{\circ} \mathrm{C}$ with the exclusion of light and under an atmosphere of argon. The resulting mixture 
was allowed to warm to room temperature and stirred at that temperature overnight. The mixture was then filtered through a pad of celite and the resulting filtrate was evaporated in vacuo. The residue was dissolved in ethyl acetate $(300 \mathrm{~mL})$ and washed with saturated $\mathrm{NaHCO}_{3}$ solution $(30 \mathrm{~mL})$, saturated $\mathrm{NaCl}$ solution $(30 \mathrm{~mL})$, dried $\left(\mathrm{Na}_{2} \mathrm{SO}_{4}\right)$ and evaporated in vacuo to leave a pale green oil. The oil was purified by silica gel chromatography using $25 \%$ ethyl acetate - hexane as eluent to give the ester $(1.07 \mathrm{~g}, 90 \%)$ as a colorless oil; IR (neat) $v_{\max } 3349,3033,2952,2868,1740,1698,1531,1455,1438,1367,1243,1169,1038,909$, 846, 775, 740 and $698 \mathrm{~cm}^{-1} ;[\alpha]_{\mathrm{D}}^{20}-20.1\left(\mathrm{c}=1.29, \mathrm{CHCl}_{3}\right)$; HRMS(EI) for $\mathrm{C}_{18} \mathrm{H}_{25} \mathrm{NO}_{6}$ : Calcd 351.1682; Found 351.1686; ${ }^{1} \mathrm{H}$ NMR (400 MHz, $\left.\mathrm{CDCl}_{3}\right) \delta 1.38-1.45(\mathrm{~m}, 2 \mathrm{H}), 1.53-1.66$ (m, 4H), $2.04(\mathrm{~s}, 3 \mathrm{H}), 2.56(\mathrm{t}, \mathrm{J}=6.2 \mathrm{~Hz}, 2 \mathrm{H}), 3.66(\mathrm{~s}, 3 \mathrm{H}), 3.96-4.01(\mathrm{~m}, 1 \mathrm{H}), 4.04(\mathrm{t}, \mathrm{J}=$ $6.5 \mathrm{~Hz}, 2 \mathrm{H}), 5.09(\mathrm{~s}, 2 \mathrm{H}), 5.22(\mathrm{~d}, \mathrm{~J}=8.7 \mathrm{~Hz}, 1 \mathrm{H}), 7.29-7.36(\mathrm{~m}, 5 \mathrm{H}) ;{ }^{13} \mathrm{C}$ NMR $(100 \mathrm{MHz}$, $\left.\mathrm{CDCl}_{3}\right) \delta 20.93,22.55,28.22,33.98,38.83,47.95,51.66,64.09,66.63,128.02,128.08$, $128.48,136.48,155.81,171.13,171.87$.

\section{Compound (7)}

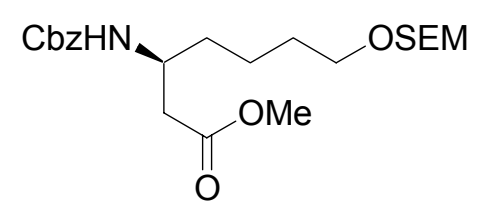

Anhydrous $\mathrm{K}_{2} \mathrm{CO}_{3}(1.74 \mathrm{~g}, 12.6 \mathrm{mmol})$ was added to a stirred solution of ester (6) $(2.22 \mathrm{~g}, 6.3 \mathrm{mmol})$ in dry methanol $(70 \mathrm{~mL})$ at $-5^{\circ} \mathrm{C}$ and under an atmosphere of argon. The resulting mixture was stirred at $0^{\circ} \mathrm{C}$ for $6 \mathrm{~h}$ and quenched by the addition of saturated $\mathrm{NaCl}$ solution $(20 \mathrm{~mL})$. The volatile solvent was removed in vacuo and the residue was extracted by ethyl acetate $(3 \times 100 \mathrm{~mL})$ and the combined extracts were dried $\left(\mathrm{Na}_{2} \mathrm{SO}_{4}\right)$ and concentrated in vacuo to leave a yellow oil. The oil was purified by silica gel chromatography using $50 \%$ ethyl acetate - hexane as eluent to give the alcohol $(1.79 \mathrm{~g}, 92 \%)$ as a colorless oil; IR (neat) $v_{\max }$ $3336,2925,2856,1736,1686,1542,1461,1436,1375,1275,1252,1221,1194,1168,1116$, $1069,1048,1033,1000,981,962,878,841,757,729,702$ and $657 \mathrm{~cm}^{-1} ;[\alpha]_{\mathrm{D}}^{20}-10.1(\mathrm{c}=$ 1.01, EA); HRMS(EI) for $\mathrm{C}_{16} \mathrm{H}_{23} \mathrm{NO}_{5}$ : Calcd 309.1576; Found 309.1572; ${ }^{1} \mathrm{H}$ NMR (400 MHz, $\left.\mathrm{CDCl}_{3}\right) \delta 1.39-1.48(\mathrm{~m}, 2 \mathrm{H}), 1.49-1.58(\mathrm{~m}, 4 \mathrm{H}), 1.99(\mathrm{br}, 1 \mathrm{H}), 2.54(\mathrm{t}, \mathrm{J}=5.7 \mathrm{~Hz}, 2 \mathrm{H})$, 
$3.61(\mathrm{t}, \mathrm{J}=6.2 \mathrm{~Hz}, 2 \mathrm{H}), 3.65(\mathrm{~s}, 3 \mathrm{H}), 3.96-4.01(\mathrm{~m}, 1 \mathrm{H}), 5.08(\mathrm{~s}, 2 \mathrm{H}), 5.24(\mathrm{~d}, \mathrm{~J}=8.8 \mathrm{~Hz}$, 1H), 7.29 - $7.35(\mathrm{~m}, 5 \mathrm{H}) ;{ }^{13} \mathrm{C} \mathrm{NMR}\left(100 \mathrm{MHz}, \mathrm{CDCl}_{3}\right) \delta 22.24,32.12,34.10,38.90,47.98$, $51.62,62.35,66.59,128.05,128.08,128.43,136.47,155.93,171.97$.

[2-(Trimethylsilyl)ethoxy]methyl chloride SEMCl $(1.7 \mathrm{~mL}, 9.6 \mathrm{mmol})$ was added dropwise to a stirred mixture of above alcohol $(1.48 \mathrm{~g}, 4.8 \mathrm{mmol})$ and diisopropylethylamine DIPEA $(3.5 \mathrm{~mL}, 20 \mathrm{mmol})$ in dry dichloromethane $(20 \mathrm{~mL})$ at $0{ }^{\circ} \mathrm{C}$ and under an atmosphere of argon. The resulting mixture was stirred at room temperature for $5 \mathrm{~h}$ and then evaporated in vacuo to leave a brown residue. The residue was dissolved in ethyl acetate $(200 \mathrm{~mL})$ and washed with saturated aqueous $\mathrm{NH}_{4} \mathrm{Cl}(40 \mathrm{~mL})$, saturated aqueous $\mathrm{NaCl}(40 \mathrm{~mL})$, dried $\left(\mathrm{Na}_{2} \mathrm{SO}_{4}\right)$ and evaporated in vacuo to leave a yellow oil. The oil was purified by silica gel chromatography using $15 \%$ ethyl acetate - hexane as eluent to give the SEM ether $(1.84 \mathrm{~g}$, $87 \%$ ) as a colorless oil; IR (neat) $v_{\max } 3336,3065,3033,2951,2871,1747,1720,1653,1527$, $1455,1438,1374,1247,1110,1027,937,921,860,836,774,753,737$ and $697 \mathrm{~cm}^{-1} ;[\alpha]_{\mathrm{D}}{ }^{20}$ -9.9 (c = 3.56, EA); HRMS(EI) for $\mathrm{C}_{22} \mathrm{H}_{37} \mathrm{NO}_{6} \mathrm{Si}$ : Calcd 439.2390; Found 439.2427; ${ }^{1} \mathrm{H}$ NMR $\left(400 \mathrm{MHz}, \mathrm{CDCl}_{3}\right) \delta 0.01(\mathrm{~s}, 9 \mathrm{H}), 0.94(\mathrm{t}, \mathrm{J}=8.5 \mathrm{~Hz}, 2 \mathrm{H}), 1.38-1.46(\mathrm{~m}, 2 \mathrm{H}), 1.53-1.61$ $(\mathrm{m}, 4 \mathrm{H}), 2.54(\mathrm{t}, \mathrm{J}=5.3 \mathrm{~Hz}, 2 \mathrm{H}), 3.51(\mathrm{t}, \mathrm{J}=6.4 \mathrm{~Hz}, 2 \mathrm{H}), 3.60(\mathrm{t}, \mathrm{J}=8.4 \mathrm{~Hz}, 2 \mathrm{H}), 3.65(\mathrm{~s}, 3 \mathrm{H})$ $3.96-3.98(\mathrm{~m}, 1 \mathrm{H}), 4.64(\mathrm{~s}, 2 \mathrm{H}), 5.08(\mathrm{~s}, 2 \mathrm{H}), 5.23(\mathrm{~d}, \mathrm{~J}=9.0 \mathrm{~Hz}, 1 \mathrm{H}), 7.28-7.35(\mathrm{~m}, 5 \mathrm{H})$; ${ }^{13} \mathrm{C}$ NMR $\left(100 \mathrm{MHz}, \mathrm{CDCl}_{3}\right) \delta-1.47$ (3C), 18.04, 22.83, 29.33, 34.16, 38.77, 48.06, 51.58, $64.91,66.53,67.41,94.72,127.97,128.00,128.42,136.50,155.75,171.87$.

\section{Compound (8)}

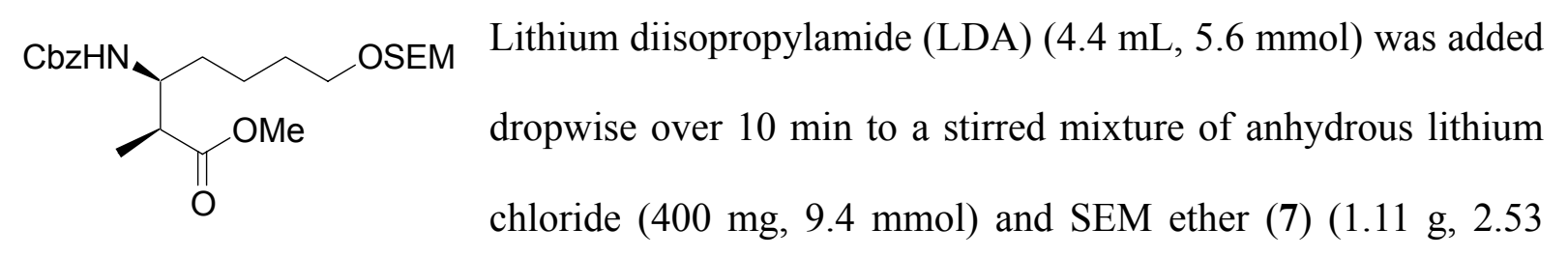

$\mathrm{mmol})$ in dry THF $(20 \mathrm{~mL})$ at $-78^{\circ} \mathrm{C}$ and under an atmosphere at argon. The resulting mixture was stirred at the same temperature for another $1 \mathrm{~h}$. Iodomethane $(1 \mathrm{~mL}, 16 \mathrm{mmol})$ was added slowly to the reaction mixture at $-78^{\circ} \mathrm{C}$ and under an atmosphere at argon. The resulting 
mixture was stirred at the same temperature overnight and then hydrolyzed with the addition of saturated $\mathrm{NH}_{4} \mathrm{Cl}$ solution $(10 \mathrm{~mL})$ at the same temperature. The mixture was dissolved in ethyl acetate $(100 \mathrm{~mL})$ and washed with saturated $\mathrm{NH}_{4} \mathrm{Cl}$ solution $(20 \mathrm{~mL})$, saturated $\mathrm{NaHCO}_{3}$ solution $(20 \mathrm{~mL})$, saturated $\mathrm{NaCl}$ solution $(20 \mathrm{~mL})$, dried $\left(\mathrm{Na}_{2} \mathrm{SO}_{4}\right)$ and evaporated in vacuo to leave a yellow oil. The oil was purified by silica gel chromatography using $15 \%$ ethyl acetate - hexane as eluent to give the ester (854 mg, 75\%) as a colorless oil; IR (neat) $v_{\max } 3425,3338,3065,3033,2951,2873,1726,1508,1457,1437,1382,1247,1109,1029$, 936, 921, 860, 836, 753, 737 and $697 \mathrm{~cm}^{-1} ;[\alpha]_{\mathrm{D}}^{20}-6.3(\mathrm{c}=1.79, \mathrm{EA})$; HRMS(EI) for $\mathrm{C}_{22} \mathrm{H}_{36} \mathrm{NO}_{6} \mathrm{Si}\left(\right.$ Loss $\mathrm{CH}_{3}$ ): Calcd 438.2312; Found 438.2314; ${ }^{1} \mathrm{H}$ NMR (400 MHz, $\left.\mathrm{CDCl}_{3}\right) \delta$ $0.01(\mathrm{~s}, 9 \mathrm{H}), 0.94(\mathrm{t}, \mathrm{J}=8.4 \mathrm{~Hz}, 2 \mathrm{H}), 1.21(\mathrm{~d}, \mathrm{~J}=7.2 \mathrm{~Hz}, 3 \mathrm{H}), 1.37-1.50(\mathrm{~m}, 4 \mathrm{H}), 1.53-1.62$ (m, 2H), $2.69(\mathrm{dq}, \mathrm{J}=4.0,7.2 \mathrm{~Hz}, 1 \mathrm{H}), 3.50(\mathrm{t}, \mathrm{J}=6.5 \mathrm{~Hz}, 2 \mathrm{H}), 3.60(\mathrm{t}, \mathrm{J}=8.4 \mathrm{~Hz}, 2 \mathrm{H}), 3.66$ (s, 3H), $3.75-3.80(\mathrm{~m}, 1 \mathrm{H}), 4.64(\mathrm{~s}, 2 \mathrm{H}), 5.10(\mathrm{~s}, 2 \mathrm{H}), 5.41(\mathrm{~d}, \mathrm{~J}=9.9 \mathrm{~Hz}, 1 \mathrm{H}), 7.28-7.36$ $(\mathrm{m}, 5 \mathrm{H}) ;{ }^{13} \mathrm{C} \mathrm{NMR}\left(100 \mathrm{MHz}, \mathrm{CDCl}_{3}\right) \delta-1.44$ (3C), 14.80, 18.08, 22.92, 29.42, 33.83, 42.68, $51.64,53.31,64.95,66.57,67.50,94.76,127.94,128.00,128.46,136.66,156.49,175.63$.

\section{Compound (12)}

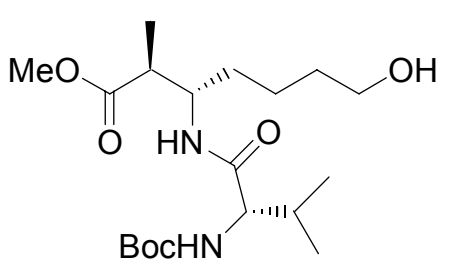

A catalytic amount of $10 \% \mathrm{Pd} / \mathrm{C}$ was added in one portion to a stirred mixture of ester (8) (448 $\mathrm{mg}, 0.99 \mathrm{mmol})$ and trifluoroacetic acid $(3 \mathrm{~mL})$ in methanol $(20 \mathrm{~mL})$. The resulting mixture was stirred at room temperature in an atmosphere of hydrogen overnight and then filtered through a pad of celite and the residue was washed with methanol $(2 \times 10 \mathrm{~mL})$. The filtrate was evaporated in vacuo to give the corresponding amine as a yellow solid which was used in the next reaction without further purification.

1-(3-dimethylaminopropyl)-3-ethylcarbodiimide hydrochloride EDCI (570 mg, $3 \mathrm{mmol})$ was added in one portion to a stirred mixture of the crude amine, N-(tert-butoxycarbonyl)-L-valine (302 mg, $1.4 \mathrm{mmol})$, 1-hydroxybenzotriazole HOBt (402 $\mathrm{mg}, 3 \mathrm{mmol})$ and N-methylmorpholine NMM $(0.8 \mathrm{~mL}, 8 \mathrm{mmol})$ in dry dichloromethane (5 
$\mathrm{mL}$ ) at $0^{\circ} \mathrm{C}$ and under an atmosphere of argon. The resulting mixture was stirred at $0^{\circ} \mathrm{C}$ for $2 \mathrm{~h}$ and at room temperature overnight. The solvent was removed in vacuo and the resulting residue was dissolved in ethyl acetate $(100 \mathrm{~mL})$ and washed with saturated $\mathrm{NaHCO}_{3}$ solution $(50 \mathrm{~mL})$ and saturated $\mathrm{NaCl}$ solution $(50 \mathrm{~mL})$. The organic layer was dried $\left(\mathrm{Na}_{2} \mathrm{SO}_{4}\right)$ and evaporated in vacuo to leave a yellow oil. The oil was purified by silica gel chromatography using 30\% ethyl acetate - hexane as eluent to give the amide (266 mg, 70\%) as a colorless viscous oil; IR (neat) $v_{\max } 3313,2960,2872,1732,1681,1650,1521,1457,1391,1367,1302$, 1249, 1172, 1046, 1019, 930, 878 and $756 \mathrm{~cm}^{-1} ;[\alpha]_{\mathrm{D}}{ }^{20}-23.7(\mathrm{c}=1.14, \mathrm{EA})$; HRMS(EI) for $\mathrm{C}_{19} \mathrm{H}_{36} \mathrm{~N}_{2} \mathrm{O}_{6}$ : Calcd 388.2573; Found 388.2575; ${ }^{1} \mathrm{H}$ NMR $\left(400 \mathrm{MHz}, \mathrm{CDCl}_{3}\right) \delta 0.90(\mathrm{~d}, \mathrm{~J}=6.8$ $\mathrm{Hz}, 3 \mathrm{H}), 0.97(\mathrm{~d}, \mathrm{~J}=6.8 \mathrm{~Hz}, 3 \mathrm{H}), 1.18(\mathrm{~d}, \mathrm{~J}=7.2 \mathrm{~Hz}, 3 \mathrm{H}), 1.36-1.60(\mathrm{~m}, 6 \mathrm{H}), 1.45(\mathrm{~s}, 9 \mathrm{H})$, $2.14-2.18(\mathrm{~m}, 1 \mathrm{H}), 2.58(\mathrm{br}, 1 \mathrm{H}), 2.68-2.71(\mathrm{~m}, 1 \mathrm{H}), 3.59(\mathrm{t}, \mathrm{J}=6.3 \mathrm{~Hz}, 2 \mathrm{H}), 3.68(\mathrm{~s}, 3 \mathrm{H})$, $3.90(\mathrm{dd}, \mathrm{J}=5.8,8.5 \mathrm{~Hz}, 1 \mathrm{H}), 4.06-4.13(\mathrm{~m}, 1 \mathrm{H}), 5.17(\mathrm{~d}, \mathrm{~J}=8.2 \mathrm{~Hz}, 1 \mathrm{H}), 6.88(\mathrm{~d}, \mathrm{~J}=9.3$ $\mathrm{Hz}, 1 \mathrm{H}) ;{ }^{13} \mathrm{C} \mathrm{NMR}\left(100 \mathrm{MHz}, \mathrm{CDCl}_{3}\right) \delta 14.88,17.54,19.38,22.13,28.19$ (3C), 30.35, 32.09, $33.24,42.39,51.01,51.63,60.29,62.13,79.72,155.80,171.76,175.79$.

\section{Compound (13)}

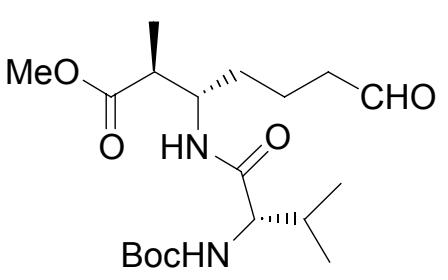

A solution of dimethyl sulfoxide $(0.4 \mathrm{~mL}, 7 \mathrm{mmol})$ in dry dichloromethane $(3 \mathrm{~mL})$ was added slowly to a stirred solution of oxalyl chloride $(0.3 \mathrm{~mL}, 3.5 \mathrm{mmol})$ in dry dichloromethane $(3 \mathrm{~mL})$ at $-78^{\circ} \mathrm{C}$ and under an atmosphere of argon. The resulting mixture was stirred at the same temperature for $20 \mathrm{~min}$ and then a pre-cooled solution of amide (12) (313 mg, $0.8 \mathrm{mmol})$ in dry dichloromethane $(3 \mathrm{~mL})$ was added slowly to the stirred mixture at $-78^{\circ} \mathrm{C}$ and under an atmosphere of argon. The resulting mixture was stirred at the same temperature for $2 \mathrm{~h}$. Diisopropylethylamine DIPEA (3 $\mathrm{mL}, 17 \mathrm{mmol})$ was added dropwise over $20 \mathrm{~min}$ at $-78^{\circ} \mathrm{C}$ and the mixture was stirred at that temperature for $1.5 \mathrm{~h}$, and at $-55^{\circ} \mathrm{C}$ for fuether $1.5 \mathrm{~h}$. A saturated $\mathrm{NH}_{4} \mathrm{Cl}$ solution $(5 \mathrm{~mL})$ was added to the reaction mixture and the separated aqueous layer was extracted by dichloromethane $(3 \times 15 \mathrm{~mL})$. The combined 
organic extracts were dried $\left(\mathrm{Na}_{2} \mathrm{SO}_{4}\right)$ and evaporated in vacuo to leave a yellow oil. The oil was purified by silica gel chromatography using $25 \%$ ethyl acetate - hexane as eluent to give the corresponding aldehyde (13) $(257 \mathrm{mg}, 82 \%)$ as a colorless viscous oil; IR (neat) $v_{\max } 3313$, $3070,2960,2872,2821,2724,1726,1679,1650,1539,1520,1456,1390,1366,1337,1303$, $1249,1172,1112,1046,1020,917,878,844,799,733$ and $647 \mathrm{~cm}^{-1} ;[\alpha]_{\mathrm{D}}^{20}-28.3(\mathrm{c}=1.55$, EA); HRMS(EI) for $\mathrm{C}_{19} \mathrm{H}_{34} \mathrm{~N}_{2} \mathrm{O}_{6}$ : Calcd 386.2417; Found 386.2414; ${ }^{1} \mathrm{H}$ NMR (400 MHz, $\left.\mathrm{CDCl}_{3}\right) \delta 0.91(\mathrm{~d}, \mathrm{~J}=6.8 \mathrm{~Hz}, 3 \mathrm{H}), 0.99(\mathrm{~d}, \mathrm{~J}=6.8 \mathrm{~Hz}, 3 \mathrm{H}), 1.19(\mathrm{~d}, \mathrm{~J}=7.2 \mathrm{~Hz}, 3 \mathrm{H}), 1.45(\mathrm{~s}$, $9 \mathrm{H}), 1.48-1.50(\mathrm{~m}, 2 \mathrm{H}), 1.62-1.67(\mathrm{~m}, 2 \mathrm{H}), 2.04-2.23(\mathrm{~m}, 1 \mathrm{H}), 2.42-2.48(\mathrm{~m}, 2 \mathrm{H})$, $2.67-2.69(\mathrm{~m}, 1 \mathrm{H}), 3.69(\mathrm{~s}, 3 \mathrm{H}), 3.92(\mathrm{dd}, \mathrm{J}=5.9,8.3 \mathrm{~Hz}, 1 \mathrm{H}), 4.08-4.12(\mathrm{~m}, 1 \mathrm{H}), 5.06(\mathrm{~d}$, $\mathrm{J}=7.5 \mathrm{~Hz}, 1 \mathrm{H}), 6.83(\mathrm{~d}, \mathrm{~J}=9.1 \mathrm{~Hz}, 1 \mathrm{H}), 9.72(\mathrm{~s}, 1 \mathrm{H}) ;{ }^{13} \mathrm{C} \mathrm{NMR}\left(100 \mathrm{MHz}, \mathrm{CDCl}_{3}\right) \delta 15.08$, $17.52,18.55,19.39,28.19(3 \mathrm{C}), 30.34,33.19,42.28,43.16,50.64,51.69,60.32,79.74,155.71$, $171.73,175.77,201.96$.

\section{Compound (14)}

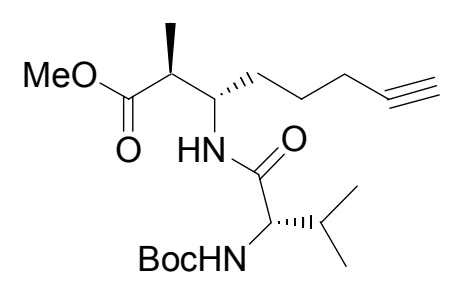

Anhydrous $\mathrm{K}_{2} \mathrm{CO}_{3}(498 \mathrm{mg}, 3.6 \mathrm{mmol})$ was added in one portion to a stirred solution of Ohira-Bestmann reagent $(700 \mathrm{mg}, 3.6$ $\mathrm{mmol})$ in dry methanol $(10 \mathrm{~mL})$ at $0^{\circ} \mathrm{C}$ and under an atmosphere of argon. The resulting mixture was stirred at $0^{\circ} \mathrm{C}$ for $30 \mathrm{~min}$ and a solution of aldehyde $(\mathbf{1 3})(257 \mathrm{mg}, 0.66 \mathrm{mmol})$ in dry methanol $(5 \mathrm{~mL})$ was added slowly to the stirred reaction mixture at the same temperature. The resulting mixture was stirred at the same temperature for $1 \mathrm{~h}$ and allowed to warm to room temperature and stirred at that temperature overnight. A saturated $\mathrm{NaCl}$ solution $(10 \mathrm{~mL})$ was added to the reaction mixture and the separated aqueous layer was extracted with dichloromethane $(3 \times 20 \mathrm{~mL})$. The combined organic extracts were dried $\left(\mathrm{Na}_{2} \mathrm{SO}_{4}\right)$ and evaporated in vacuo to leave a yellow oil. The oil was purified by silica gel chromatography using $15 \%$ ethyl acetate - hexane as eluent to give the corresponding alkyne (14) $(235 \mathrm{mg}, 93 \%)$ as a colorless oil; IR (neat) $v_{\max } 3317$, 2959, 2873, 2118, 1732, 1681, 1651, 1556, 1504, 1435, 1392, 1367, 1304, 1173, 1075, 1046, 
1019, 930, 878, 844, 755 and $666 \mathrm{~cm}^{-1} ;[\alpha]_{\mathrm{D}}^{20}-28.9(\mathrm{c}=2,38, \mathrm{EA})$; HRMS(EI) for $\mathrm{C}_{20} \mathrm{H}_{34} \mathrm{~N}_{2} \mathrm{O}_{5}$ : Calcd 382.2468; Found 382.2469; ${ }^{1} \mathrm{H}$ NMR $\left(400 \mathrm{MHz}, \mathrm{CDCl}_{3}\right) \delta 0.92(\mathrm{~d}, \mathrm{~J}=6.9$ $\mathrm{Hz}, 3 \mathrm{H}), 0.98(\mathrm{~d}, \mathrm{~J}=6.8 \mathrm{~Hz}, 3 \mathrm{H}), 1.18(\mathrm{~d}, \mathrm{~J}=7.2 \mathrm{~Hz}, 3 \mathrm{H}), 1.45(\mathrm{~s}, 9 \mathrm{H}), 1.49-1.66(\mathrm{~m}, 4 \mathrm{H})$, $1.93(\mathrm{t}, \mathrm{J}=2.6 \mathrm{~Hz}, 1 \mathrm{H}), 2.18-2.22(\mathrm{~m}, 3 \mathrm{H}), 2.68-2.73(\mathrm{~m}, 1 \mathrm{H}), 3.69(\mathrm{~s}, 3 \mathrm{H}), 3.90(\mathrm{dd}, \mathrm{J}=$ 5.7, 8.4 Hz, 1H), $4.08-4.12(\mathrm{~m}, 1 \mathrm{H}), 5.07(\mathrm{~d}, \mathrm{~J}=7.9 \mathrm{~Hz}, 1 \mathrm{H}), 6.78(\mathrm{~d}, \mathrm{~J}=9.1 \mathrm{~Hz}, 1 \mathrm{H}) ;{ }^{13} \mathrm{C}$ NMR (400 MHz, $\left.\mathrm{CDCl}_{3}\right) \delta 15.04,17.52,17.93,19.38,24.81,28.19$ (3C), 30.32, 32.80, 42.43, $50.52,51.62,60.30,68.66,79.66,83.75,155.66,171.58,175.78$.

\section{Compound (15)}<smiles>CC(C)[C@H](O)C(=O)O[Ga]c1ccccc1</smiles>

Water $(200 \mathrm{~mL})$ was added to a three-necked flask containing L-valine (23.4 g, $0.2 \mathrm{~mol})$. The flask was fitted with two addition funnels, one containing $2 \mathrm{~N}$ sulphuric acid $(150 \mathrm{~mL}, 0.3 \mathrm{~mol})$ and another a solution of $\mathrm{NaNO}_{2}(20.7 \mathrm{~g}, 0.3 \mathrm{~mol})$ in water $(150 \mathrm{~mL})$. The acid was added dropwise to the stirred reaction mixture at $0^{\circ} \mathrm{C}$. After the L-valine had dissolved, the $\mathrm{NaNO}_{2}$ solution was added dropwise with the same rate of the addition as the acid. After the addition was complete, the resulting mixture was stirred at $0^{\circ} \mathrm{C}$ for $3 \mathrm{~h}$, allowed to warm to room temperature and stirred at that temperature overnight. The mixture was extracted by ethyl acetate $(5 \times 200 \mathrm{~mL})$. The combined organic extracts were dried $\left(\mathrm{Na}_{2} \mathrm{SO}_{4}\right)$ and evaporated in vacuo to give (S)-2-Hydroxy-3-methylbutyric acid (12 g, 50\%) as a colourless viscous oil which was used in the next reaction without further purification.

A 1:99 (w/v) solution of $\mathrm{I}_{2}$ in dichloromethane $(1.6 \mathrm{~mL})$ was added to a mixture of (S)-2-hydroxy-3-methyl-butyric acid (1.44 g, $12 \mathrm{mmol})$ and benzophenone hydrazone (3.59 g, $18.3 \mathrm{mmol})$ in dry dichloromethane $(25 \mathrm{~mL})$ at $-10^{\circ} \mathrm{C}$. The resulting mixture was stirred for 10 min and iodobenzene diacetate $(5.9 \mathrm{~g}, 18.3 \mathrm{mmol})$ was added in several portions over $30 \mathrm{~min}$ to the stirred reaction mixture at $-10^{\circ} \mathrm{C}$. The mixture was stirred at that temperature for $2 \mathrm{~h}$ and at room temperature for a further $2 \mathrm{~h}$. The solvent was evaporated in vacuo to leave a yellow residue. The residue was purified by silica gel chromatography using $10 \%$ ethyl acetate - 
hexane as eluent to give the (S)-2-hydroxy-3-methyl-butyric acid benzhydryl ester (2 g, 60\%) as a colorless viscous oil; ${ }^{1} \mathrm{H}$ NMR $\left(400 \mathrm{MHz}, \mathrm{CDCl}_{3}\right) \delta 0.77(\mathrm{~d}, \mathrm{~J}=6.9 \mathrm{~Hz}, 3 \mathrm{H}), 1.02(\mathrm{~d}, \mathrm{~J}=$ $7.0 \mathrm{~Hz}, 3 \mathrm{H}), 2.17(\mathrm{dq}, \mathrm{J}=3.3,6.9 \mathrm{~Hz}, 1 \mathrm{H}), 2.68(\mathrm{~d}, \mathrm{~J}=2.5 \mathrm{~Hz}, 1 \mathrm{H}), 4.16(\mathrm{dd}, \mathrm{J}=3.3,5.7 \mathrm{~Hz}$, 1H), $6.96(\mathrm{~s}, 1 \mathrm{H}), 7.27-7.36(\mathrm{~m}, 10 \mathrm{H}) ;{ }^{13} \mathrm{C} \mathrm{NMR}\left(400 \mathrm{MHz}, \mathrm{CDCl}_{3}\right) \delta 15.61,18.90,32.14$, $74.99,78.22,127.02,127.25,128.15,128.22,128.56,139.41,139.45,174,17$.<smiles>CC(C)[C@H](O)C(=O)OCC(Cl)(Cl)Cl</smiles>

Dicyclohexylcarbodiimide DCC (9.5 g, $46 \mathrm{mmol})$ was added in one portion to a stirred mixture of (S)-2-hydroxy-3-methyl-butyric acid (4.7 g, $40 \mathrm{mmol})$, 2,2,2-trichloroethanol $(3.87 \mathrm{~mL}, 40 \mathrm{mmol})$, 4-dimethylaminopyridine DMAP (5.6 g, 46 mmol) and 98\% (1R)-(-)-10-camphorsulfonic acid CSA $(1.86 \mathrm{~g}, 8 \mathrm{mmol})$ in dry dichloromethane $(30 \mathrm{~mL})$ at $0^{\circ} \mathrm{C}$ and under an atmosphere of argon. The resulting mixture was stirred at $0^{\circ} \mathrm{C}$ for $2 \mathrm{~h}$ and stirred at room temperature overnight. The mixture was filtered through a pad of celite and the residue was washed with hexane $(2 \times 20 \mathrm{~mL})$. The combined organic layers were concentrated in vacuo to leave a residue which was dissolved in ethyl acetate $(300 \mathrm{~mL})$ and washed with saturated $\mathrm{NH}_{4} \mathrm{Cl}$ solution $(50 \mathrm{~mL})$, saturated $\mathrm{NaCl}$ solution $(50 \mathrm{~mL})$, dried $\left(\mathrm{Na}_{2} \mathrm{SO}_{4}\right)$ and evaporated in vacuo to leave a pale yellow oil. The oil was purified by silica gel chromatography using $5 \%$ ethyl acetate - hexane as eluent to give (S)-2-hydroxy-3-methylbutyric acid 2,2,2-trichloro-ethyl ester $(6.85 \mathrm{~g}, 69 \%)$ as a colorless oil; IR (neat) $v_{\max } 3479,2914,2878,1749,1403,1369,1334$, $1316,1271,1179,1130,1061,1037,1014,9553,891,816,760$ and $715 \mathrm{~cm}^{-1} ;[\alpha]_{\mathrm{D}}{ }^{20}-12.50$ $(\mathrm{c}=1.2, \mathrm{EA}) ;{ }^{1} \mathrm{H}$ NMR $\left(400 \mathrm{MHz}, \mathrm{CDCl}_{3}\right) \delta 0.94(\mathrm{~d}, \mathrm{~J}=6.9 \mathrm{~Hz}, 3 \mathrm{H}), 1.09(\mathrm{~d}, \mathrm{~J}=6.9 \mathrm{~Hz}, 3 \mathrm{H})$, $2.16-2.22(\mathrm{~m}, 1 \mathrm{H}), 2.60(\mathrm{~d}, \mathrm{~J}=6.5 \mathrm{~Hz}, 1 \mathrm{H}), 4.21(\mathrm{dd}, \mathrm{J}=3.0,6.4 \mathrm{~Hz}, 1 \mathrm{H}), 4.83(\mathrm{dd}, \mathrm{J}=11.9$, 83.6 Hz, 1H); ${ }^{13} \mathrm{C}$ NMR $\left(100 \mathrm{MHz}, \mathrm{CDCl}_{3}\right) \delta 15.93,18.79,32.11,74.56,75.10,94.33$, 173.43.<smiles>CC(C)C(C(=O)O[C@H](C(=O)OC(c1ccccc1)c1ccccc1)C(C)C)N(C)[14C](=O)O[Na]</smiles>

$60 \%$ Sodium hydride $(5 \mathrm{~g}, 0.125 \mathrm{~mol})$ was added in one portion to a stirred mixture Cbz-L-valine $(9.5 \mathrm{~g}, 0.038 \mathrm{~mol})$ in dry THF $(150 \mathrm{~mL})$ at $0^{\circ} \mathrm{C}$ and stirred for $30 \mathrm{~min}$ at the same temperature 
under an atmosphere of argon. Iodomethane $(20 \mathrm{~mL}, 0.32 \mathrm{~mol})$ was added and the resulting mixture was stirred overnight at room temperature. Iced water $(200 \mathrm{~mL})$ was poured into the mixture at $0^{\circ} \mathrm{C}$ and the resulting mixture was extracted with diethyl ether $(2 \times 200 \mathrm{~mL})$. The aqueous layer was acidified to $\mathrm{pH} 1.5$ using dilute $\mathrm{HCl}$ solution and extracted with ethyl acetate $(3 \times 200 \mathrm{~mL})$. The combined organic extracts were washed with saturated sodium thiosulphate solution $(100 \mathrm{~mL})$, dried $\left(\mathrm{Na}_{2} \mathrm{SO}_{4}\right)$ and evaporated in vacuo to give $\mathrm{N}$-methyl-N-Cbz-L-valine ( $5 \mathrm{~g}, 55 \%$ ) as a colorless viscous oil which was used in the next step without purification.

Dicyclohexylcarbodiimide DCC (1 g, $5 \mathrm{mmol}$ ) was added in one portion to a stirred mixture of N-methyl-N-Cbz-L-valine (636 mg, $2.5 \mathrm{mmol}$ ), (S)-2-hydroxy-3-methyl-butyric acid benzhydryl ester (502 mg, 2 mmol), 4-dimethylaminopyridine DMAP (610 mg, 5 mmol) and 98\% (1R)-(-)-10-camphorsulfonic acid (CSA) (93 mg, $0.4 \mathrm{mmol})$ in dry dichloromethane $(10 \mathrm{~mL})$ at $0^{\circ} \mathrm{C}$ and under an atmosphere of argon. The resulting mixture was stirred at $0^{\circ} \mathrm{C}$ for $2 \mathrm{~h}$ and then at room temperature overnight. The mixture was filtered through a pad of celite and the residue was washed with hexane $(2 \times 10 \mathrm{~mL})$. The combined washings were concetrated in vacuo to leave a residue which was dissolved in ethyl acetate $(100 \mathrm{~mL})$ and washed with saturated $\mathrm{NH}_{4} \mathrm{Cl}$ solution $(25 \mathrm{~mL})$, saturated $\mathrm{NaCl}$ solution $(25 \mathrm{~mL})$, dried $\left(\mathrm{Na}_{2} \mathrm{SO}_{4}\right)$ and evaporated in vacuo to leave a pale yellow oil. The oil was purified by silica gel chromatography using $10 \%$ ethyl acetate - hexane as eluent to give (S)-2-(benzyloxycarbonyl-methyl-amino)-3-methyl-butyric acid 1-benzhydryloxy carbonyl-2-methyl-propyl ester (930 mg, 93\%) as a colorless oil; IR (neat) $v_{\max } 3472,3090,3065,3033,2966,2936$, $2877,1749,1701,1604,1587,1496,1455,1402,1372,1305,1198,1126,1024,996,912$, $869,844,754,697$ and $600 \mathrm{~cm}^{-1} ;[\alpha]_{\mathrm{D}}{ }^{20}-64.6(\mathrm{c}=8.48, \mathrm{EA}) ;{ }^{1} \mathrm{H}$ NMR $\left(400 \mathrm{MHz}, \mathrm{CDCl}_{3}\right) \delta$ $0.77-1.05(\mathrm{~m}, 12 \mathrm{H}), 2.16-2.27(\mathrm{~m}, 2 \mathrm{H}), 2.89,2.91(\mathrm{~s}, 3 \mathrm{H}), 4.7,4.60(\mathrm{~d}, \mathrm{~J}=10.4 \mathrm{~Hz}, 1 \mathrm{H})$, 4.94, $4.97(\mathrm{~d}, \mathrm{~J}=4.2 \mathrm{~Hz}, 1 \mathrm{H}), 5.14(\mathrm{~d}, \mathrm{~J}=4.5 \mathrm{~Hz}, 2 \mathrm{H}), 6.92,6.93(\mathrm{~s}, 1 \mathrm{H}), 7.22-7.34(\mathrm{~m}$, $15 \mathrm{H}) ;{ }^{13} \mathrm{C}$ NMR $\left(400 \mathrm{MHz}, \mathrm{CDCl}_{3}\right) \delta 16.69,16.75,18.56,18.66,18.81,18.84,19.55,27.41$, 
$27.48,29.93,30.00,30.47,30.69,63.97,64.30,67.24,67.30,76.94,76.96,77.64,77.01$, $126.81,126.85,127.36,127.60,127.64,127.80,128.00,128.28,128.33,136.37,136.51$, $139.20,139.22,139.33,156.02,156.68,168.18,168.26,170.17,170.57$.<smiles>CC(C)C(C(=O)O[C@@H](C(=O)O[C@@H](C(=O)N[C@H](C(=O)OCCCl)C(C)C)C(C)C)C(C)C)C(C)C</smiles>

Trifluoroacetic acid $(5 \mathrm{~mL})$ was added dropwise to a stirred solution of (S)-2-(benzyloxycarbonylmethyl -amino)-3-methyl-butyric acid 1-benzhydryloxycarbonyl-2-methyl-propyl ester $(472 \mathrm{mg}, 0.95 \mathrm{mmol})$ in dry dichloromethane $(5 \mathrm{~mL})$ at $0^{\circ} \mathrm{C}$ and under an atmosphere of argon. The resulting mixture was stirred at $0^{\circ} \mathrm{C}$ for $10 \mathrm{~h}$. The reaction mixture was poured into a mixture of benzene and chloroform $(1: 1,10 \mathrm{~mL})$ and evaporated in vacuo to give 2-(benzyloxycarbonyl-methyl-amino)-3-methyl-butyric acid 1-carboxy-2-methyl-propyl ester as a brown residue which was used in the next reaction without further purification.

Dicyclohexylcarbodiimide DCC (488 $\mathrm{mg}, 2.4 \mathrm{mmol}$ ) was added in one portion to a stirred mixture of 2-(benzyloxycarbonylmethylamino)-3-methyl-butyric acid 1-carboxy-2-methyl-propyl ester, (S)-2-hydroxy-3-methyl-butyric acid 2,2,2-trichloro-ethyl ester (236 mg, $0.95 \mathrm{mmol})$, 4-dimethylaminopyridine DMAP (289 mg, $2.4 \mathrm{mmol}$ ) and 98\% (1R)-(-)-10-camphorsulfonic acid CSA (44 mg, $0.19 \mathrm{mmol})$ in dry dichloromethane $(4 \mathrm{~mL})$ at $0^{\circ} \mathrm{C}$ and under an atmosphere of argon. The resulting mixture was stirred at $0^{\circ} \mathrm{C}$ for $2 \mathrm{~h}$ then at room temperature overnight. The mixture was filtered through a pad of celite and the residue was washed with hexane $(2 \times 5 \mathrm{~mL})$. The combined filtrate was evaporated in vacuo to leave a residue which was dissolved in ethyl acetate $(50 \mathrm{~mL})$ and washed with saturated $\mathrm{NH}_{4} \mathrm{Cl}$ solution $(15 \mathrm{~mL})$, saturated $\mathrm{NaCl}$ solution $(15 \mathrm{~mL})$, dried $\left(\mathrm{Na}_{2} \mathrm{SO}_{4}\right)$ and evaporated in vacuo to leave a pale yellow oil. The oil was purified by silica gel chromatography using $10 \%$ ethyl acetate - hexane as eluent to give the corresponding ester (397 mg, 70\%) as a colorless oil; IR (neat) $v_{\max } 3464,3091,3066,3034,2968,2938,2878,1747,1699,1497,1469,1455,1392$, $1373,1289,1241,1191,1125,1029,984,910,821,768,718$ and $698 \mathrm{~cm}^{-1} ;[\alpha]_{\mathrm{D}}{ }^{20}-63.3(\mathrm{c}=$ 
3.83, EA); $\mathrm{HRMS}(\mathrm{EI})$ for $\mathrm{C}_{26} \mathrm{H}_{36} \mathrm{NCl}_{3} \mathrm{O}_{8}$ : Calcd 595.1507; Found 595.1508; ${ }^{1} \mathrm{H}$ NMR (400 $\left.\mathrm{MHz}, \mathrm{CDCl}_{3}\right) \delta 0.90-1.11(\mathrm{~m}, 18 \mathrm{H}), 2.22-2.42(\mathrm{~m}, 3 \mathrm{H}), 2.90(\mathrm{~s}, 3 \mathrm{H}), 4.39,4.58(\mathrm{~d}, \mathrm{~J}=$ $10.6 \mathrm{~Hz}, 1 \mathrm{H}), 4.69(\mathrm{~d}, \mathrm{~J}=11.9 \mathrm{~Hz}, 1 \mathrm{H}), 4.89-4.94(\mathrm{~m}, 2 \mathrm{H}), 5.06(\mathrm{~d}, \mathrm{~J}=4.0 \mathrm{~Hz}, 1 \mathrm{H}), 5.18(\mathrm{t}$, $\mathrm{J}=4.4 \mathrm{~Hz}, 2 \mathrm{H}), 7.29-7.38(\mathrm{~m}, 5 \mathrm{H}) ;{ }^{13} \mathrm{C} \mathrm{NMR}\left(100 \mathrm{MHz}, \mathrm{CDCl}_{3}\right) \delta 15.93,16.87,16.93$, $16.99,18.67,18.75,18.77,18.95,19.01,19.65,27.60,27.72,30.02,30.10,30.67,30.75$, $32.10,64.08,64.33,67.41,67.49,74.24,74.53,76.71,76.83,94.36,127.73,127.81,127.88$, $127.95,128.44,136.50,136.65,156.20,156.85,167.66,168.87,168.93,170.40,170.80$.

A catalytic amount of $10 \% \mathrm{Pd} / \mathrm{C}$ was added in one portion to a stirred mixture of the above ester) and $1 \mathrm{~N}$ hydrogen chloride in methanol $(2 \mathrm{~mL})$ in methanol $(8 \mathrm{~mL})$. The resulting mixture was stirred at room temperature in an atmosphere of hydrogen for $4 \mathrm{~h}$ and then filtered through a pad of celite and the residue was washed with methanol $(2 \times 10 \mathrm{~mL})$. The filtrate was evaporated in vacuo to give the corresponding amine (15) which was used in the next reaction without further purification.

\section{Compound (16)}

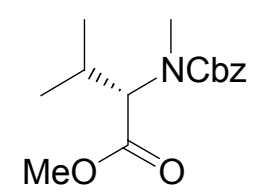

Cesium carbonate $(3.5 \mathrm{~g}, 10 \mathrm{mmol})$ was added to a stirred mixture of $\mathrm{N}$-carbobenzyloxy-L-valine $(1.26 \mathrm{~g}, 5 \mathrm{mmol})$ and iodomethane $(2 \mathrm{~mL}, 30$ mmol) in dry DMF $(50 \mathrm{~mL})$ at room temperature and under an atmosphere of argon. The resulting mixture was stirred at the room temperature overnight and then dissolved in a mixture of ethyl acetate and benzene $(3: 1,400 \mathrm{~mL})$ and washed with saturated $\mathrm{NH}_{4} \mathrm{Cl}$ solution $(50 \mathrm{~mL})$, saturated $\mathrm{NaHCO}_{3}$ solution $(50 \mathrm{~mL})$, saturated $\mathrm{NaCl}$ solution $(50 \mathrm{~mL})$, dried $\left(\mathrm{Na}_{2} \mathrm{SO}_{4}\right)$ and evaporated in vacuo to leave a yellow oil. The oil was purified by silica gel chromatography using $10 \%$ ethyl acetate - hexane as eluent to give 2-(benzyloxycarbonyl-methyl-amino)-3-methyl-butyric acid methyl ester (1.33 g, 95\%) as a colorless oil; IR (neat) $v_{\max } 3065,3033,2965,2876,1747,1702,1498,1401,1371,1307$, $1262,1206,1149,1009,978,768,736$ and $697 \mathrm{~cm}^{-1} ;[\alpha]_{\mathrm{D}}{ }^{20}-87.8(\mathrm{c}=2.64, \mathrm{EA}) ; \mathrm{HRMS}(\mathrm{EI})$ for $\mathrm{C}_{15} \mathrm{H}_{21} \mathrm{NO}_{4}$ : Calcd 279.1471; Found 279.1479; ${ }^{1} \mathrm{H}$ NMR $\left(400 \mathrm{MHz}, \mathrm{CDCl}_{3}\right) \delta 0.87(\mathrm{~d}, \mathrm{~J}=$ 
$6.7 \mathrm{~Hz}), 0.90(\mathrm{~d}, \mathrm{~J}=6.7 \mathrm{~Hz}, 3 \mathrm{H}), 0.95(\mathrm{~d}, \mathrm{~J}=6.5 \mathrm{~Hz}), 0.98(\mathrm{~d}, \mathrm{~J}=6.5 \mathrm{~Hz}, 3 \mathrm{H}), 2.13-2.22(\mathrm{~m}$, 1H), $2.91(\mathrm{~s}, 3 \mathrm{H}), 3.65,3.69(\mathrm{~s}, 3 \mathrm{H}), 4.31(\mathrm{~d}, \mathrm{~J}=10.6 \mathrm{~Hz}), 4.52(\mathrm{~d}, \mathrm{~J}=10.6 \mathrm{~Hz}, 1 \mathrm{H}), 5.15$, $5.16(\mathrm{~s}, 2 \mathrm{H}), 7.26-7.33(\mathrm{~m}, 5 \mathrm{H}) ;{ }^{13} \mathrm{C} \mathrm{NMR}\left(100 \mathrm{MHz}, \mathrm{CDCl}_{3}\right) \delta 18.63,18.73,19.39,19.47$, $27.38,29.86,30.28,51.50,63.63,64.13,67.15,67.23,127.51,127.75,128.24,136.44,156.02$, $156.74,170.99,171.44$.<smiles>COC(=O)N[C@@H](C)[C@H](C)C(=O)N(C)[C@@H](C(=O)OC)C(C)C</smiles>
16
A catalytic amount of $10 \% \mathrm{Pd} / \mathrm{C}$ was added in one portion to a stirred mixture of 2-(benzyloxycarbonyl-methyl-amino)-3-methyl-butyric

acid methyl ester $(380 \mathrm{mg}, 1.36 \mathrm{mmol})$ and $1 \mathrm{~N}$ hydrogen chloride in methanol $(2 \mathrm{~mL})$ in methanol $(8 \mathrm{~mL})$. The resulting mixture was stirred at room temperature in an atmosphere of hydrogen for $4 \mathrm{~h}$ and then filtered through a pad of celite and the residue was washed with methanol $(2 \times 10 \mathrm{~mL})$. The filtrate was evaporated in vacuo to give $\mathrm{N}$-methyl valine methyl ester as a yellow solid which was used in the next reaction without further purification.

Solid lithium hydroxide monohydrate $(420 \mathrm{mg}, 10.5 \mathrm{mmol}$ ) was added in one portion to a stirred solution of ester $(\mathbf{8})(479 \mathrm{mg}, 1.05 \mathrm{mmol}) \mathrm{in} \mathrm{THF} / \mathrm{MeOH} /$ water $(2 / 2 / 1,10 \mathrm{~mL})$ at $0^{\circ} \mathrm{C}$. After $1 \mathrm{~h}$, the reaction mixture was allowed to warm at room temperature and stirred at that temperature overnight. The mixture was poured into diethyl ether $(20 \mathrm{~mL})$ and acidified to $\mathrm{pH} 2$ using dilute aqueous $\mathrm{KHSO}_{4}$ solution at $0^{\circ} \mathrm{C}$. The separated aqueous layer was extracted with ethyl acetate $(3 \times 30 \mathrm{~mL})$ and the combined organic extracts were dried $\left(\mathrm{Na}_{2} \mathrm{SO}_{4}\right)$ and evaporated in vacuo to give the corresponding acid as a colorless oil which was used in the next reaction without further purification.

Diispropylethylamine $(1.46 \mathrm{~mL}, 8.4 \mathrm{mmol})$ was added dropwise to a stirred mixture of above acid, N-methyl valine methyl ester, 1-hydroxy-7-azabenzotriazole (HOAt) (163 mg, $1.26 \mathrm{mmol}$ ) and 2-bromo-1-ethyl pyridinium tetrafluoroborate (BEP) (700 mg, $2.6 \mathrm{mmol})$ in dry dichloromethane $(5 \mathrm{~mL})$ at $-25^{\circ} \mathrm{C}$ and under an atmosphere of argon. The resulting mixture was stirred at the same temperature for $1 \mathrm{~h}$ and allowed to warm to room temperature 
and stirred at that temperature overnight. The solvent was removed in vacuo and the resulting residue was dissolved in ethyl acetate $(100 \mathrm{~mL})$ and washed with saturated $\mathrm{NH}_{4} \mathrm{Cl}$ solution $(20 \mathrm{~mL})$, saturated $\mathrm{NaHCO}_{3}$ solution $(20 \mathrm{~mL})$ and saturated $\mathrm{NaCl}$ solution $(20 \mathrm{~mL})$. The organic layer was dried $\left(\mathrm{Na}_{2} \mathrm{SO}_{4}\right)$ and evaporated in vacuo to leave a yellow oil. The oil was purified by silica gel chromatography using $20 \%$ ethyl acetate - hexane as eluent to give the corresponding amide (16) $(280 \mathrm{mg}, 47 \%)$ as a colorless viscous oil; IR (neat) $v_{\max } 3396,3333$, $3065,3033,2952,2874,1720,1637,1500,1458,1411,1373,1254,1211,1061,1027,936$, 859, 836, 736 and $697 \mathrm{~cm}^{-1}$; HRMS(EI) for $\mathrm{C}_{29} \mathrm{H}_{50} \mathrm{~N}_{2} \mathrm{O}_{7} \mathrm{Si}$ : Calcd 566.3387; Found 566.3389; (1S,2S,3S)-isomer (16): $[\alpha]_{\mathrm{D}}{ }^{20}-53.2(\mathrm{c}=3.64, \mathrm{EA}) ;{ }^{1} \mathrm{H}$ NMR $\left(400 \mathrm{MHz}, \mathrm{CDCl}_{3}\right) \delta-0.01(\mathrm{~s}$, 9H), $0.80(\mathrm{~d}, \mathrm{~J}=6.8 \mathrm{~Hz}, 3 \mathrm{H}), 0.90(\mathrm{t}, \mathrm{J}=8.5 \mathrm{~Hz}, 2 \mathrm{H}), 0.98(\mathrm{~d}, \mathrm{~J}=6.5 \mathrm{~Hz}, 3 \mathrm{H}), 1.16(\mathrm{~d}, \mathrm{~J}=$ $7.1 \mathrm{~Hz}, 3 \mathrm{H}), 1.32-1.42(\mathrm{~m}, 3 \mathrm{H}), 1.46-1.56(\mathrm{~m}, 3 \mathrm{H}), 2.17-2.20(\mathrm{~m}, 1 \mathrm{H}), 2.94-2.95(\mathrm{~m}$, 1H), 2.82, $2.97(\mathrm{~s}, 3 \mathrm{H}), 3.45(\mathrm{t}, \mathrm{J}=10.2 \mathrm{~Hz}, 2 \mathrm{H}), 3.56(\mathrm{t}, \mathrm{J}=8.4 \mathrm{~Hz}, 2 \mathrm{H}), 3.66,3.70(\mathrm{~s}, 3 \mathrm{H})$, $3.71-3.73(\mathrm{~m}, 1 \mathrm{H}), 4.60(\mathrm{~s}, 2 \mathrm{H}), 4.81(\mathrm{~d}, \mathrm{~J}=10.5 \mathrm{~Hz}, 1 \mathrm{H}), 5.06(\mathrm{~s}, 2 \mathrm{H}), 6.36(\mathrm{~d}, \mathrm{~J}=9.6 \mathrm{~Hz}$ 1H), $7.24-7.31(\mathrm{~m}, 5 \mathrm{H}) ;{ }^{13} \mathrm{C}$ NMR $\left(100 \mathrm{MHz}, \mathrm{CDCl}_{3}\right) \delta-1.53(3 \mathrm{C}), 14.89,15.02,17.95$, $18.54,18.74,19.45,19.82,22.95,23.13,27.23,27.63,29.41,29.44,31.72,33.92,38.07$, $38.70,51.71,52.04,54.01,54.30,61.06,64.80,65.66,66.14,67.44,94.61,127.57,127.66$, $128.23,136.83,156.72,156.76,170.14,171.16,176.46,176.48$

The isomer 16a was synthesized according to the above procedure from ent-8, which was in turn synthesized from D-Lysine.

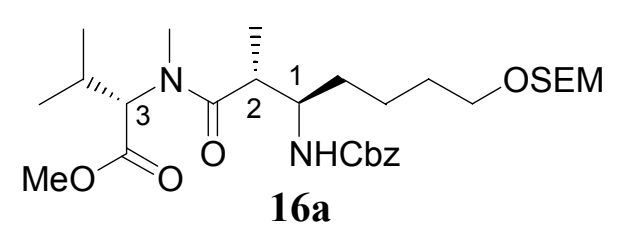

$(1 \mathrm{R}, 2 \mathrm{R}, 3 \mathrm{~S})-$ isomer $(\mathbf{1 6 a}):[\alpha]_{\mathrm{D}}^{20}-61.1 \quad(\mathrm{c}=1.30$, $\left.\mathrm{CHCl}_{3}\right) ;{ }^{1} \mathrm{H} \mathrm{NMR}\left(400 \mathrm{MHz}, \mathrm{CDCl}_{3}\right) \delta 0.02(\mathrm{~s}, 9 \mathrm{H})$, $0.85(\mathrm{~d}, \mathrm{~J}=6.5 \mathrm{~Hz}, 3 \mathrm{H}), 0.93(\mathrm{t}, \mathrm{J}=8.1 \mathrm{~Hz}, 2 \mathrm{H}), 1.01(\mathrm{~d}$, $\mathrm{J}=6.2 \mathrm{~Hz}, 3 \mathrm{H}), 1.18(\mathrm{~d}, \mathrm{~J}=6.9 \mathrm{~Hz}, 3 \mathrm{H}), 1.35-1.48(\mathrm{~m}, 3 \mathrm{H}), 1.50-1.56(\mathrm{~m}, 3 \mathrm{H}), 2.17-$ $2.26(\mathrm{~m}, 1 \mathrm{H}), 2.95-2.97(\mathrm{~m}, 1 \mathrm{H}), 2.86,3.02(\mathrm{~s}, 3 \mathrm{H}), 3.48(\mathrm{t}, \mathrm{J}=6.4 \mathrm{~Hz}, 2 \mathrm{H}), 3.59(\mathrm{t}, \mathrm{J}=8.2$ $\mathrm{Hz}, 2 \mathrm{H}), 3.69,3.72(\mathrm{~s}, 3 \mathrm{H}), 3.71-3.73(\mathrm{~m}, 1 \mathrm{H}), 4.63(\mathrm{~s}, 2 \mathrm{H}), 4.82(\mathrm{~d}, \mathrm{~J}=10.5 \mathrm{~Hz}, 1 \mathrm{H}), 5.08$ $(\mathrm{s}, 2 \mathrm{H}), 6.34(\mathrm{~d}, \mathrm{~J}=9.6 \mathrm{~Hz}), 6.39,(\mathrm{~d}, \mathrm{~J}=9.6 \mathrm{~Hz}, 1 \mathrm{H}), 7.28-7.34(\mathrm{~m}, 5 \mathrm{H}) ;{ }^{13} \mathrm{C} \mathrm{NMR}(100$ 
$\left.\mathrm{MHz}, \mathrm{CDCl}_{3}\right) \delta-1.41$ (3C), 14.69, 15.64, 18.11, 18.98, 19.03, 19.63, 19.81, 23.00, 23.18, $27.21,27.74,29.57,29.66,31.73,34.14,38.21,38.35,51.87,52.06,54.06,54.51,61.33$, $64.96,65.88,66.29,67.54,67.63,94.76,127.71,127.79,128.38,136.94,156.83,171.51$, $176.55,176.65$.

\section{Compound (18)}

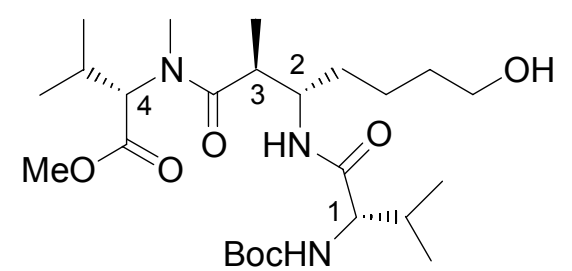

18

Trifluoroacetic acid $(6 \mathrm{~mL})$ was added dropwise to a stirred solution of amide (16) (669 $\mathrm{mg}, 1.18 \mathrm{mmol})$ in dry dichloromethane $(6 \mathrm{~mL})$ at $0^{\circ} \mathrm{C}$ and under an atmosphere of argon. The resulting mixture was stirred at $0^{\circ} \mathrm{C}$ overnight.

The reaction mixture was poured into a mixture of benzene and chloroform $(1: 1,50 \mathrm{~mL})$ and evaporated in vacuo to give the corresponding alcohol (464 $\mathrm{mg}, 90 \%$ ) as a brown residue which was used in the next reaction without further purification.

A catalytic amount of $10 \% \mathrm{Pd} / \mathrm{C}$ was added in one portion to a stirred mixture of the above alcohol (464 mg, $1.06 \mathrm{mmol})$ and $1 \mathrm{~N}$ hydrogen chloride in methanol $(5 \mathrm{~mL})$ in methanol $(10 \mathrm{~mL})$. The resulting mixture was stirred at room temperature in an atmosphere of hydrogen overnight and then filtered through a pad of celite and the residue was washed with methanol $(2 \times 30 \mathrm{~mL})$. The filtrate was evaporated in vacuo to give the amine $(\mathbf{1 7})$ as a yellow solid which was used in the next reaction without further purification.

1-(3-dimethylaminopropyl)-3-ethylcarbodiimide hydrochloride EDCI (960 mg, 5 mmol) was added in one portion to a stirred mixture of the above amine (17), N-(tert-butoxycarbonyl)-L-valine (235 mg, $1.1 \mathrm{mmol})$, 1-hydroxybenzotriazole (HOBt) (674 $\mathrm{mg}, 5 \mathrm{mmol})$ and $\mathrm{N}$-methylmorpholine $(\mathrm{NMM})(1.1 \mathrm{~mL}, 10 \mathrm{mmol})$ in dry dichloromethane (5 $\mathrm{mL}$ ) at $0^{\circ} \mathrm{C}$ and under an atmosphere of argon. The resulting mixture was stirred at $0^{\circ} \mathrm{C}$ for $2 \mathrm{~h}$ then at room temperature overnight. The solvent was removed in vacuo and the resulting residue was dissolved in ethyl acetate $(100 \mathrm{~mL})$ and washed with saturated $\mathrm{NaHCO}_{3}$ solution $(20 \mathrm{~mL})$ and saturated $\mathrm{NaCl}$ solution $(20 \mathrm{~mL})$. The organic layer was dried $\left(\mathrm{Na}_{2} \mathrm{SO}_{4}\right)$ and 
evaporated in vacuo to leave a yellow oil. The oil was purified by silica gel chromatography using $1 \%$ methanol - chloroform as eluent to give amide (18) (266 mg, 50\%) as a colorless viscous oil; IR (neat) $v_{\max } 3379,2967,2935,2875,1739,1707,1651,1505,1412,1391,1246$, $1204,1171,1093,1046,1015,928,872,755$ and $665 \mathrm{~cm}^{-1}$; HRMS(EI) for $\mathrm{C}_{25} \mathrm{H}_{47} \mathrm{~N}_{3} \mathrm{O}_{7}$ : Calcd 501.3414; Found 501.3413; (1S,2S,3S,4S)-isomer $(\mathbf{1 8})$ : $[\alpha]_{\mathrm{D}}{ }^{20}=-76.6(\mathrm{c}=4.28, \mathrm{EA}) ;{ }^{1} \mathrm{H}$ NMR (400 MHz, $\left.\mathrm{CDCl}_{3}\right) \delta 0.83(\mathrm{~d}, \mathrm{~J}=6.7 \mathrm{~Hz}, 3 \mathrm{H}), 0.93(\mathrm{~d}, \mathrm{~J}=7.0 \mathrm{~Hz}), 0.90(\mathrm{~d}, \mathrm{~J}=6.9 \mathrm{~Hz}$, $3 \mathrm{H}), 1.00(\mathrm{~d}, \mathrm{~J}=6.9 \mathrm{~Hz}, 3 \mathrm{H}), 1.02(\mathrm{~d}, \mathrm{~J}=6.5 \mathrm{~Hz}, 3 \mathrm{H}), 1.19(\mathrm{~d}, \mathrm{~J}=7.4 \mathrm{~Hz}), 1.16(\mathrm{~d}, \mathrm{~J}=7.0 \mathrm{~Hz}$ $3 \mathrm{H}), 1.31-1.42(\mathrm{~m}, 3 \mathrm{H}), 1.43(\mathrm{~s}, 9 \mathrm{H}), 1.48-1.59(\mathrm{~m}, 3 \mathrm{H}), 2.17-2.26(\mathrm{~m}, 2 \mathrm{H}), 2.42(\mathrm{br}, 1 \mathrm{H})$ $2.98-3.04(\mathrm{~m}, 1 \mathrm{H}), 2.85,3.02(\mathrm{~s}, 3 \mathrm{H}), 3.58(\mathrm{t}, \mathrm{J}=6.2 \mathrm{~Hz}, 2 \mathrm{H}), 3.72,3.73(\mathrm{~s}, 3 \mathrm{H}), 3.96-3.99$ (m, 1H), $4.02-4.09(\mathrm{~m}, 1 \mathrm{H}), 4.90(\mathrm{~d}, \mathrm{~J}=10.5 \mathrm{~Hz}, 1 \mathrm{H}), 5.09(\mathrm{~d}, \mathrm{~J}=8.2 \mathrm{~Hz}, 1 \mathrm{H}), 7.80$ (d, J = $9.2 \mathrm{~Hz}, 1 \mathrm{H}) ;{ }^{13} \mathrm{C} \mathrm{NMR}\left(100 \mathrm{MHz}, \mathrm{CDCl}_{3}\right) \delta 15.17,15.34,17.16,17.24,18.60,18.82,19.49$, $19.83,22.24,22.43,27.25,27.65,28.19,28.23$ (3C), 28.64, 30.52, 30.61, 31.62, 32.23, 33.68, $33.89,37.69,38.50,51.85,51.92,52.10,52.22,60.03,60.28,60.85,62.10,62.25,65.74$, $79.48,155.64,170.13,171.31,171.71,171.82,176.71,176.79$

The isomer 18a was synthesized according to the above procedure from $\mathbf{1 6 a}$

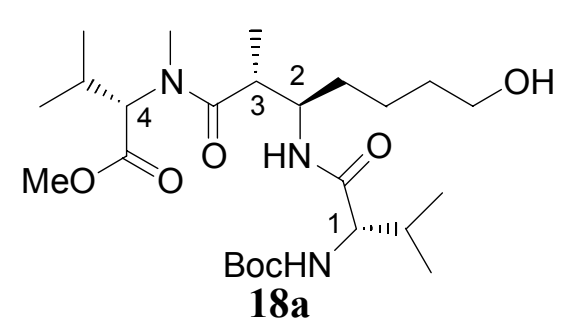

$(1 \mathrm{~S}, 2 \mathrm{R}, 3 \mathrm{R}, 4 \mathrm{~S})$-isomer (18a): $[\alpha]_{\mathrm{D}}^{20}-39.5(\mathrm{c}=1.30$, $\left.\mathrm{CHCl}_{3}\right) ;{ }^{1} \mathrm{H} \mathrm{NMR}\left(400 \mathrm{MHz}, \mathrm{CDCl}_{3}\right) \delta 0.86(\mathrm{~d}, \mathrm{~J}=6.7 \mathrm{~Hz}$, 3H), $0.91(\mathrm{~d}, \mathrm{~J}=6.9 \mathrm{~Hz}, 3 \mathrm{H}), 0.98(\mathrm{~d}, \mathrm{~J}=6.8 \mathrm{~Hz}, 3 \mathrm{H}), 1.02$ $(\mathrm{d}, \mathrm{J}=6.6 \mathrm{~Hz}, 3 \mathrm{H}), 1.16(\mathrm{~d}, \mathrm{~J}=7.0 \mathrm{~Hz}, 3 \mathrm{H}), 1.35-1.41(\mathrm{~m}$, 2H), $1.45(\mathrm{~s}, 9 \mathrm{H}), 1.50-1.52(\mathrm{~m}, 2 \mathrm{H}), 1.55-1.60(\mathrm{~m}, 2 \mathrm{H}), 2.17(\mathrm{br}, 1 \mathrm{H}), 2.18-2.26(\mathrm{~m}, 2 \mathrm{H})$ 2.97 (dq, J = 3.4, 7.1 Hz, 1H), 2.89, 3.04 (s, 3H), 3.59 (t, J = 6.1 Hz, 2H), 3.72, 3.75 (s, 3H), $3.94-4.03(\mathrm{~m}, 1 \mathrm{H}), 4.04-4.08(\mathrm{~m}, 1 \mathrm{H}), 4.84(\mathrm{~d}, \mathrm{~J}=10.5 \mathrm{~Hz}, 1 \mathrm{H}), 5.17(\mathrm{~d}, \mathrm{~J}=7.4 \mathrm{~Hz}, 1 \mathrm{H})$, $7.76(\mathrm{~d}, \mathrm{~J}=9.2 \mathrm{~Hz}, 1 \mathrm{H}) ;{ }^{13} \mathrm{C}$ NMR $\left(100 \mathrm{MHz}, \mathrm{CDCl}_{3}\right) \delta 14.68,15.76,17.44,18.92,18.98$, $19.16,19.33,19.50,19.74,22.20,22.39,27.10,27.68,28.20$ (3C), 28.31, 30.53, 30.63, 31.61, $31.77,32.19,32.29,33.76,37.48,37.70,51.77,51.81,52.06,52.25,60.00,60.13,61.29$, $62.09,62.16,65.89,79.47,155.67,170.39,171.31,171.67,176.60,176.81$. 


\section{Compound (19)}

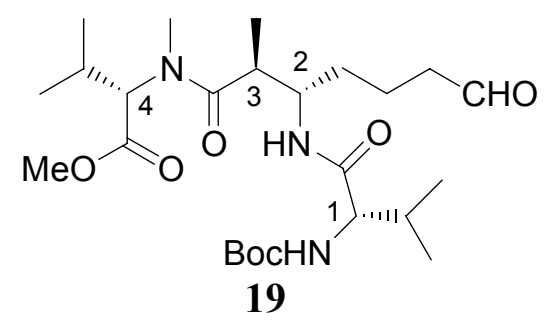

A solution of dimethyl sulfoxide $(228 \mu \mathrm{L}, 3.88 \mathrm{mmol})$ in dry dichloromethane $(5 \mathrm{~mL})$ was added slowly to a stirred solution of oxalyl chloride $(170 \mu \mathrm{L}, 1.94 \mathrm{mmol})$ in dry dichloromethane $(5 \mathrm{~mL})$ at $-78^{\circ} \mathrm{C}$ and under an atmosphere

of argon. The resulting mixture was stirred at the same temperature for $20 \mathrm{~min}$ and then a solution of amide (18) (243 mg, $0.485 \mathrm{mmol})$ in dry dichloromethane $(5 \mathrm{~mL})$ was added slowly to the stirred mixture at $-78^{\circ} \mathrm{C}$ and under an atmosphere of argon. The resulting mixture was stirred at the same temperature for $2 \mathrm{~h}$. Diisopropylethylamine $(1.69 \mathrm{~mL}, 9.7$ mmol) was added dropwise over $20 \mathrm{~min}$ at $-78^{\circ} \mathrm{C}$ and the mixture was stirred at that temperature for $1.5 \mathrm{~h}$, then at $-55^{\circ} \mathrm{C}$ for a further $1.5 \mathrm{~h}$. Saturated $\mathrm{NH}_{4} \mathrm{Cl}$ solution $(10 \mathrm{~mL})$ was added to the reaction mixture and the separated aqueous layer was extracted with dichloromethane $(3 \times 50 \mathrm{~mL})$. The combined organic extracts were dried $\left(\mathrm{Na}_{2} \mathrm{SO}_{4}\right)$ and evaporated in vacuo to leave a yellow oil. The oil was purified by silica gel chromatography using 50\% ethyl acetate - hexane as eluent to give aldehyde (19) (212 mg, 87\%) as a colorless viscous oil; (1S,2S,3S,4S)-(19) IR $v_{\max }$ 3365, 2966, 2935, 2875, 2724, 1715, 1651, 1634, $1504,1412,1391,1367,1245,1171,1092,1044,1014,929,872,755$ and $665 \mathrm{~cm}^{-1} ;[\alpha]_{\mathrm{D}}^{20}$ -84.876 (c = 0.88, EA); HRMS(EI) for $\mathrm{C}_{25} \mathrm{H}_{45} \mathrm{~N}_{3} \mathrm{O}_{7}$ : Calcd 499.3258; Found 499.3254; ${ }^{1} \mathrm{H}$ NMR (400 MHz, $\left.\mathrm{CDCl}_{3}\right) \delta 0.82(\mathrm{~d}, \mathrm{~J}=6.7 \mathrm{~Hz}, 3 \mathrm{H}), 0.90(\mathrm{~d}, \mathrm{~J}=6.9 \mathrm{~Hz}, 3 \mathrm{H}), 1.00(\mathrm{~d}, \mathrm{~J}=7.1$ Hz, 3H), 1.02 (d, J = 6.7 Hz, 3H), 1.15 (d, J = 7.2 Hz), 1.12 (d, J = 7.1 Hz, 3H), 1.41 (s, 9H), $1.34-1.48(\mathrm{~m}, 2 \mathrm{H}), 1.53-1.60(\mathrm{~m}, 2 \mathrm{H}), 2.14-2.21(\mathrm{~m}, 2 \mathrm{H}), 2.41(\mathrm{t}, \mathrm{J}=6.9 \mathrm{~Hz}, 2 \mathrm{H}), 2.93$ $(\mathrm{dq}, \mathrm{J}=3.3,7.1 \mathrm{~Hz}, 1 \mathrm{H}), 2.80,2.97(\mathrm{~s}, 3 \mathrm{H}), 3.67,2.69$ (s, 3H), $3.92-3.97(\mathrm{~m}, 1 \mathrm{H}), 4.00-$ $4.02(\mathrm{~m}, 1 \mathrm{H}), 4.84(\mathrm{~d}, \mathrm{~J}=10.6 \mathrm{~Hz}, 1 \mathrm{H}), 5.01(\mathrm{~d}, \mathrm{~J}=8.2 \mathrm{~Hz}, 1 \mathrm{H}), 7.77(\mathrm{~d}, \mathrm{~J}=9.2 \mathrm{~Hz}, 1 \mathrm{H})$, $9.72(\mathrm{~s}, 1 \mathrm{H}) ;{ }^{13} \mathrm{C} \mathrm{NMR}\left(100 \mathrm{MHz}, \mathrm{CDCl}_{3}\right) \delta 15.22,15.35,17.18,17.26,18.53,18.64,18.78$, $19.45,19.79,27.24,27.62,28.16(3 \mathrm{C}), 28.20,28.64,30.46,30.57,31.57,33.41,33.47,37.84$, $38.53,43.12,43.19,51.49,51.74,51.84,52.10,60.03,60.80,65.76,79.47,155.57,170.03$, 
$171.12,171.75,171.81,176.55,176.65,202.10$.

\section{Compound (20)}

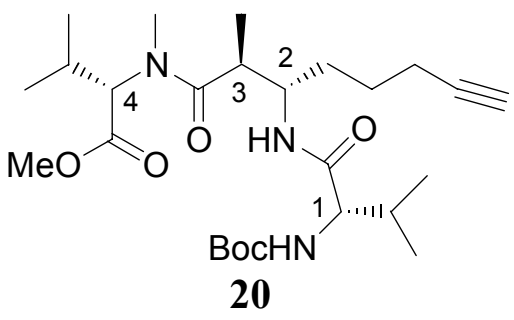

Anhydrous $\mathrm{K}_{2} \mathrm{CO}_{3}(300 \mathrm{mg}, 2.18 \mathrm{mmol}$ ) was added in one portion to a stirred solution of Ohira-Bestmann reagent (418 $\mathrm{mg}, 2.18 \mathrm{mmol})$ in dry methanol $(5 \mathrm{~mL})$ at $0^{\circ} \mathrm{C}$ and under an atmosphere of argon. The resulting mixture was stirred at $0^{\circ} \mathrm{C}$ for $30 \mathrm{~min}$ and a solution of aldehyde (19) $(217 \mathrm{mg}, 0.44 \mathrm{mmol})$ in dry methanol $(5 \mathrm{~mL})$ was added slowly to the stirred reaction mixture at the same temperature. The resulting mixture was stirred for $1 \mathrm{~h}$, allowed to warm to room temperature and stirred at that temperature overnight. A saturated $\mathrm{NaCl}$ solution $(10 \mathrm{~mL})$ was added to the reaction mixture and the separated aqueous layer was extracted by dichloromethane $(4 \times 50 \mathrm{~mL})$. The combined organic extracts were dried $\left(\mathrm{Na}_{2} \mathrm{SO}_{4}\right)$ and evaporated in vacuo to leave a yellow oil. The oil was purified by silica gel chromatography using 30\% ethyl acetate - hexane as eluent to give alkyne (20) (176 mg, 80\%) as a colorless viscous oil; IR (neat) $v_{\max } 3311,2966,2933,2875$, $2118,1739,1714,1651,1514,1412,1391,1367,1245,1172,1089,1042,1014,928,871$, 755 and $665 \mathrm{~cm}^{-1}$; HRMS(EI) for $\mathrm{C}_{26} \mathrm{H}_{45} \mathrm{~N}_{3} \mathrm{O}_{6}$ : Calcd 495.3308; Found 495,3297; $(1 \mathrm{~S}, 2 \mathrm{~S}, 3 \mathrm{~S}, 4 \mathrm{~S})$-isomer (20): $[\alpha]_{\mathrm{D}}{ }^{20}-86.68(\mathrm{c}=1.79, \mathrm{EA}):{ }^{1} \mathrm{H}$ NMR $\left(400 \mathrm{MHz}, \mathrm{CDCl}_{3}\right) \delta 0.81$ $(\mathrm{d}, \mathrm{J}=6.7 \mathrm{~Hz}, 3 \mathrm{H}), 0.88(\mathrm{~d}, \mathrm{~J}=6.9 \mathrm{~Hz}, 3 \mathrm{H}), 0.89(\mathrm{~d}, \mathrm{~J}=6.8 \mathrm{~Hz}), 0.92(\mathrm{~d}, \mathrm{~J}=6.7 \mathrm{~Hz}), 0.98(\mathrm{~d}$, $\mathrm{J}=6.9 \mathrm{~Hz}, 3 \mathrm{H}), 1.00(\mathrm{~d}, \mathrm{~J}=6.5 \mathrm{~Hz}, 3 \mathrm{H}), 1.18(\mathrm{~d}, \mathrm{~J}=7.1 \mathrm{~Hz}), 1.15(\mathrm{~d}, \mathrm{~J}=7.1 \mathrm{~Hz}, 3 \mathrm{H}), 1.43(\mathrm{~s}$, 9H), $1.47-1.53(\mathrm{~m}, 4 \mathrm{H}), 1.90(\mathrm{t}, \mathrm{J}=2.6 \mathrm{~Hz}, 1 \mathrm{H}), 2.14-2.23(\mathrm{~m}, 4 \mathrm{H}), 2.96(\mathrm{dq}, \mathrm{J}=3.3,7.4$ Hz, 1H), 2.84, $3.00(\mathrm{~s}, 3 \mathrm{H}), 3.71,3.72(\mathrm{~s}, 3 \mathrm{H}), 3.95-4.00(\mathrm{~m}, 1 \mathrm{H}), 4.04-4.08(\mathrm{~m}, 1 \mathrm{H}), 4.89$ $(\mathrm{d}, \mathrm{J}=10.6 \mathrm{~Hz}, 1 \mathrm{H}), 5.03(\mathrm{~d}, \mathrm{~J}=8.2 \mathrm{~Hz}, 1 \mathrm{H}), 7.75(\mathrm{~d}, \mathrm{~J}=9.1 \mathrm{~Hz}, 1 \mathrm{H}) ;{ }^{13} \mathrm{C}$ NMR $(100 \mathrm{MHz}$, $\left.\mathrm{CDCl}_{3}\right) \delta 15.35,15.53,17.24,17.33,17.93,18.05,18.58,18.94,19.55,19.87,25.03,25.06$, $27.28,27.72,28.26,28.30(3 \mathrm{C}), 28.71,30.60,30.73,31.65,33.26,33.42,38.09,38.77,51.53$, $51.78,51.91,52.18,60.09,60.85,65.91,68.59,79.55,83.99,155.66,170.15,171.24,171.73$, $176.80,176.82$ 
The isomer $\mathbf{2 0 a}$ was synthesized according to the above procedures from $\mathbf{1 8 a}$.

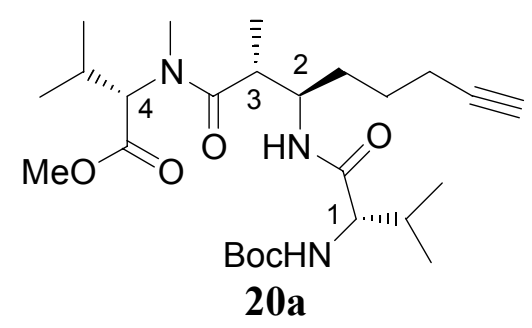

$(1 \mathrm{~S}, 2 \mathrm{R}, 3 \mathrm{R}, 4 \mathrm{~S})$-isomer $(\mathbf{2 0 a}):[\alpha]_{\mathrm{D}}{ }^{20}-57.1\left(\mathrm{c}=1.90, \mathrm{CHCl}_{3}\right)$;

${ }^{1} \mathrm{H}$ NMR $\left(400 \mathrm{MHz}, \mathrm{CDCl}_{3}\right) \delta 0.88(\mathrm{~d}, \mathrm{~J}=6.7 \mathrm{~Hz}, 3 \mathrm{H}), 0.91$ $(\mathrm{d}, \mathrm{J}=6.9 \mathrm{~Hz}, 3 \mathrm{H}), 0.98(\mathrm{~d}, \mathrm{~J}=6.9 \mathrm{~Hz}, 3 \mathrm{H}), 1.03(\mathrm{~d}, \mathrm{~J}=6.5$ $\mathrm{Hz}, 3 \mathrm{H}), 1.17(\mathrm{~d}, \mathrm{~J}=7.1 \mathrm{~Hz}, 3 \mathrm{H}), 1.44(\mathrm{~s}, 9 \mathrm{H}), 1.48-1.60$

(m, 4H), $1.91(\mathrm{t}, \mathrm{J}=2.6 \mathrm{~Hz}, 1 \mathrm{H}), 2.10-2.26(\mathrm{~m}, 4 \mathrm{H}), 2.96(\mathrm{dq}, \mathrm{J}=3.4,7.0 \mathrm{~Hz}, 1 \mathrm{H}), 2.89$, $3.05(\mathrm{~s}, 3 \mathrm{H}), 3.72,3.77(\mathrm{~s}, 3 \mathrm{H}), 3.96-4.01(\mathrm{~m}, 1 \mathrm{H}), 4.06-4.10(\mathrm{~m}, 1 \mathrm{H}), 4.85(\mathrm{~d}, \mathrm{~J}=10.6 \mathrm{~Hz}$, 1H), $5.16(\mathrm{~d}, \mathrm{~J}=7.9 \mathrm{~Hz}, 1 \mathrm{H}), 7.68(\mathrm{~d}, \mathrm{~J}=9.2 \mathrm{~Hz}, 1 \mathrm{H}), 7.73(\mathrm{~d}, \mathrm{~J}=9.7 \mathrm{~Hz}) ;{ }^{13} \mathrm{C} \mathrm{NMR}(100$ $\left.\mathrm{MHz}, \mathrm{CDCl}_{3}\right) \delta 14.79,15.84,17.48,17.53,18.01,19.00,19.10,19.40,19.57,19.85,19.78$ $24.95,25.13,27.18,27.67,28.26(3 \mathrm{C}), 30.86,31.04,31.79,33.05,33.23,37.62,38.07,51.08$, 51.36, 51.86, 52.16, 59.98, 60.12, 61.32, 65.89, 68.50, 68.65, 79.46, 83.78, 155.67, 170.31, $171.36,171.67,176.62,176.84$.

\section{Compound (23)}

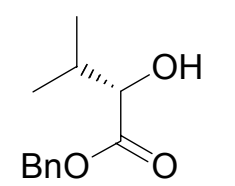

Benzyl bromide $(5.95 \mathrm{~mL}, 50 \mathrm{mmol})$ was added dropwise to a stirred mixture of (S)-2-hydroxy-3-methyl-butyric acid (1.18 g, $10 \mathrm{mmol})$ and anhydrous $\mathrm{NaHCO}_{3}$ (1.68 g, $20 \mathrm{mmol})$ in dry DMF (30 mL) under an atmosphere of argon. The resulting mixture was stirred at the same temperature overnight and the mixture was dissolved in ethyl acetate $(300 \mathrm{~mL})$ and washed with water $(2 \times 50 \mathrm{~mL})$, saturated $\mathrm{NH}_{4} \mathrm{Cl}$ solution $(50 \mathrm{~mL})$ and saturated $\mathrm{NaCl}$ solution $(50 \mathrm{~mL})$. The organic layer was dried $\left(\mathrm{Na}_{2} \mathrm{SO}_{4}\right)$ and evaporated in vacuo to leave a yellow oil. The oil was purified by silica gel chromatography using $10 \%$ ethyl acetate - hexane as eluent to give (S)-2-hydroxy-3-methyl-butyric acid benzyl ester (1.64 g, $80 \%$ ) as a colorless oil; IR (neat) $v_{\max } 3504,3066,3034,2964,2933,2875,1735,1498,1465$, $1456,1388,1370,1261,1137,1106,1070,1029,990,913,830,751$ and $698 \mathrm{~cm}^{-1} ;[\alpha]_{\mathrm{D}}^{20}$ $14.4(\mathrm{c}=1.17, \mathrm{EA})$; HRMS(EI) for $\mathrm{C}_{12} \mathrm{H}_{16} \mathrm{O}_{3}$ : Calcd 208.1099; Found 208.1093; ${ }^{1} \mathrm{H}$ NMR $\left(300 \mathrm{MHz}, \mathrm{CDCl}_{3}\right) \delta 0.83(\mathrm{~d}, \mathrm{~J}=6.9 \mathrm{~Hz}, 3 \mathrm{H}), 0.99(\mathrm{~d}, \mathrm{~J}=6.9 \mathrm{~Hz}, 3 \mathrm{H}), 2.01-2.11(\mathrm{~m}, 1 \mathrm{H})$, $2.91(\mathrm{~d}, \mathrm{~J}=6.1 \mathrm{~Hz}, 1 \mathrm{H}), 4.07(\mathrm{dd}, \mathrm{J}=3.6,6.2 \mathrm{~Hz}, 1 \mathrm{H}), 5.20(\mathrm{~d}, \mathrm{~J}=12.2,18.3 \mathrm{~Hz}, 2 \mathrm{H}), 7.34(\mathrm{~s}$ 
$5 \mathrm{H}) ;{ }^{13} \mathrm{C} \mathrm{NMR}\left(75 \mathrm{MHz}, \mathrm{CDCl}_{3}\right) \delta 15.82,18.65,32.05,67.06,74.94,128.28,128.39,128.49$, $135.15,174.65$.

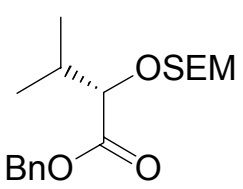

[2-(Trimethylsilyl)ethoxy]methyl chloride $(1.84 \mathrm{~mL}, 10.4 \mathrm{mmol})$ was added dropwise to a stirred mixture of (S)-2-hydroxy-3-methyl-butyric acid benzyl ester (1.442 $\mathrm{g}, 6.93 \mathrm{mmol})$ and diisopropylethylamine $(5.2 \mathrm{~mL}, 30 \mathrm{mmol})$ in dry dichloromethane $(15 \mathrm{~mL})$ at $0^{\circ} \mathrm{C}$ and under an atmosphere of argon. The resulting mixture was stirred at room temperature overnight and then evaporated in vacuo to leave a brown residue. The residue was dissolved in ethyl acetate $(200 \mathrm{~mL})$ and washed with saturated $\mathrm{NH}_{4} \mathrm{Cl}$ solution $(50 \mathrm{~mL})$, saturated $\mathrm{NaCl}$ solution $(50 \mathrm{~mL})$, dried $\left(\mathrm{Na}_{2} \mathrm{SO}_{4}\right)$ and evaporated in vacuo to leave a yellow oil. The oil was purified by silica gel chromatography using $5 \%$ ethyl acetate - hexane as eluent to give (S)-3-methyl-2-(2-trimethylsilanyl-ethoxymethoxy)-butyric acid benzyl ester $(2.07 \mathrm{~g}, 88 \%)$ as a colorless oil; IR (neat) $v_{\max } 3066,3035,2957,2893,1749$, $1498,1456,1385,1368,1249,1183,1156,1131,1119,1057,1039,936,918,860,835,750$ and $696 \mathrm{~cm}^{-1} ;[\alpha]_{\mathrm{D}}{ }^{20}-56.7(\mathrm{c}=2.72, \mathrm{EA}) ;{ }^{1} \mathrm{H} \mathrm{NMR}\left(400 \mathrm{MHz}, \mathrm{CDCl}_{3}\right) \delta 0.01(\mathrm{~s}, 9 \mathrm{H}), 0.89$ $(\mathrm{dd}, \mathrm{J}=8.2,8.9 \mathrm{~Hz}, 2 \mathrm{H}), 0.94(\mathrm{~d}, \mathrm{~J}=6.4 \mathrm{~Hz}, 3 \mathrm{H}), 0.96(\mathrm{~d}, \mathrm{~J}=6.4 \mathrm{~Hz}, 3 \mathrm{H}), 2.09-2.14(\mathrm{~m}$, 1H), $3.59-3.69(\mathrm{~m}, 2 \mathrm{H}), 3.96(\mathrm{~d}, \mathrm{~J}=5.4 \mathrm{~Hz}, 1 \mathrm{H}), 4.71(\mathrm{~s}, 2 \mathrm{H}), 5.18(\mathrm{dd}, \mathrm{J}=12.3,14.0 \mathrm{~Hz}$, 2H), $7.30-7.37(\mathrm{~m}, 5 \mathrm{H}) ;{ }^{13} \mathrm{C} \mathrm{NMR}\left(100 \mathrm{MHz}, \mathrm{CDCl}_{3}\right) \delta-1.51$ (3C), 17.48, 17.92, 18.72, $31.38,65.57,66.30,80.31,94.42,128.23(2 \mathrm{C}), 128.47,135.63,172.14$.<smiles>[M]O[C@H](C(=O)O[C@H](C(=O)OCC)C(C)C)C(C)C</smiles>

A catalytic amount of $10 \% \mathrm{Pd} / \mathrm{C}$ was added in one portion to a stirred mixture of (S)-3-methyl-2-(2-trimethylsilanylethoxymethoxy)-butyric acid benzyl ester (1.43 g, $3.97 \mathrm{mmol})$ in methanol $(30 \mathrm{~mL})$. The resulting mixture was stirred at room temperature in an atmosphere of hydrogen for $4 \mathrm{~h}$ and then filtered through a pad of celite and the residue was washed with $\mathrm{MeOH}(2 \times 30 \mathrm{~mL})$. The combined filtrates were evaporated in vacuo to give (S)-3-methyl-2-(2-trimethylsilanyl-ethoxymethoxy)-butyric acid as a yellow oil which was used in the next reaction without further purification. 
Dicyclohexylcarbodiimide $(1.69 \mathrm{~g}, 8.2 \mathrm{mmol})$ was added in one portion to a stirred mixture of (S)-3-methyl-2-(2-trimethylsilanyl-ethoxymethoxy)-butyric acid, (S)-2-hydroxy

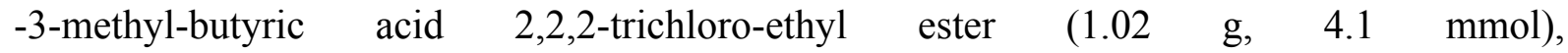
4-dimethylaminopyridine (1.0 g, $8.2 \mathrm{mmol})$ and (1R)-(-)-10-camphorsulfonic acid (0.18 g, 0.8 mmol) in dry dichloromethane $(15 \mathrm{~mL})$ at $0^{\circ} \mathrm{C}$ and under an atmosphere of argon. The resulting mixture was stirred at $0^{\circ} \mathrm{C}$ for $2 \mathrm{~h}$ and stirred at room temperature overnight. The mixture was filtered through a pad of celite and the residue was washed with hexanes $(2 \times 20$ $\mathrm{mL}$ ). The filtrate was evaporated in vacuo to leave a residue which was dissolved in ethyl acetate $(200 \mathrm{~mL})$ and washed with saturated $\mathrm{NH}_{4} \mathrm{Cl}$ solution $(50 \mathrm{~mL})$, saturated $\mathrm{NaCl}$ solution $(50 \mathrm{~mL})$, dried $\left(\mathrm{Na}_{2} \mathrm{SO}_{4}\right)$ and evaporated in vacuo to leave a pale yellow oil. The oil was purified by silica gel chromatography using $2 \%$ ethyl acetate - hexane as eluent to give the corresponding ester (23) $(1.54 \mathrm{~g}, 81 \%)$ as a colorless viscous oil; IR (neat) $v_{\max } 2962,2893$, $1756,1467,1391,1372,1328,1276,1248,1179,1058,989,936,919,860,835,768,718$, 694, 665 and $572 \mathrm{~cm}^{-1} ;[\alpha]_{\mathrm{D}}{ }^{20}-68.2(\mathrm{c}=1.8, \mathrm{EA})$; HRMS(FAB) for $\mathrm{C}_{18} \mathrm{H}_{32} \mathrm{ClO}_{6} \mathrm{Si}$ (Loss $\mathrm{HCl}_{2}$ ): Calcd 407.1657; Found 4071667; ${ }^{1} \mathrm{H} \mathrm{NMR}\left(400 \mathrm{MHz}, \mathrm{CDCl}_{3}\right) \delta 0.02$ (s, 9H), $0.88-$ $0.93(\mathrm{~m}, 2 \mathrm{H}), 1.02(\mathrm{~d}, \mathrm{~J}=6.8 \mathrm{~Hz}, 3 \mathrm{H}), 1.05(\mathrm{~d}, \mathrm{~J}=6.7 \mathrm{~Hz}, 3 \mathrm{H}), 1.06(\mathrm{~d}, \mathrm{~J}=6.1 \mathrm{~Hz}, 3 \mathrm{H}), 1.08$ $(\mathrm{d}, \mathrm{J}=6.2 \mathrm{~Hz}, 3 \mathrm{H}), 2.19-2.24(\mathrm{~m}, 1 \mathrm{H}), 2.33-2.38(\mathrm{~m}, 1 \mathrm{H}), 3.56-3.63(\mathrm{~m}, 1 \mathrm{H}), 3.68-3.75$ (m, 1H), $4.10(\mathrm{~d}, \mathrm{~J}=4.7 \mathrm{~Hz}, 1 \mathrm{H}), 4.75(\mathrm{~s}, 2 \mathrm{H}), 4.81(\mathrm{dd}, \mathrm{J}=12.0,67.2 \mathrm{~Hz}, 1 \mathrm{H}), 5.01(\mathrm{~d}, \mathrm{~J}=$ 4.1 Hz, 1H); ${ }^{13} \mathrm{C}$ NMR (100 MHz, $\left.\mathrm{CDCl}_{3}\right) \delta-1.46$ (3C), 17.03, 17.16, 18.03, 18.83, 18.92, $30.07,31.47,65.66,74.22,76.47,79.40,94.25,94.40,167.90,172.00$.

\section{Compound (22)}<smiles>CCOC(=O)[C@H](OC(=O)C(O)C(C)C)C(C)C</smiles>

22

Trifluoroacetic acid $(6 \mathrm{~mL})$ was added dropwise to a stirred solution of (S, S)-3- methyl-2-(2-trimethylsilanyl-ethoxymethoxy)-butyric acid 2-methyl-1-(2,2,2-trichloro- ethoxycarbonyl)-propyl ester (1 g, $2.1 \mathrm{mmol})$ in dry dichloromethane $(6 \mathrm{~mL})$ at $0^{\circ} \mathrm{C}$ and under an atmosphere of argon. The resulting mixture was stirred at $0^{\circ} \mathrm{C}$ for $5 \mathrm{~h}$. The reaction mixture 
was poured into a mixture of benzene and chloroform $(1: 1,30 \mathrm{~mL})$ and evaporated in vacuo to leave a brown residue. The residue was purified by silica gel chromatography using $12 \%$ ethyl acetate - hexane as eluent to give the corresponding alcohol (22) (624 $\mathrm{mg}, 85 \%)$ as a clolorless oil; IR (neat) $v_{\max }$ 3522, 2970, 2936, 2879, 1771, 1746, 1469, 1393, 1373, 1179, 1129, 1033, 964, 905, 821, 769, 719 and $571 \mathrm{~cm}^{-1} ;[\alpha]_{\mathrm{D}}{ }^{20}-19.0\left(\mathrm{c}=3.5, \mathrm{CHCl}_{3}\right) ;{ }^{1} \mathrm{H} \mathrm{NMR}$ $\left(400 \mathrm{MHz}, \mathrm{CDCl}_{3}\right) \delta 0.98(\mathrm{~d}, \mathrm{~J}=6.9 \mathrm{~Hz}, 3 \mathrm{H}), 1.05(\mathrm{~d}, \mathrm{~J}=6.9 \mathrm{~Hz}, 3 \mathrm{H}), 1.08(\mathrm{~d}, \mathrm{~J}=6.9 \mathrm{~Hz}$, $3 \mathrm{H}), 1.09(\mathrm{~d}, \mathrm{~J}=6.9 \mathrm{~Hz}, 3 \mathrm{H}), 2.20(\mathrm{dq}, \mathrm{J}=3.6,6.9 \mathrm{~Hz}, 1 \mathrm{H}), 2.39(\mathrm{dq}, \mathrm{J}=4.0,6.9 \mathrm{~Hz}, 1 \mathrm{H})$, $2.46(\mathrm{br}, 1 \mathrm{H}), 4.16(\mathrm{~d}, \mathrm{~J}=3.6 \mathrm{~Hz}, 1 \mathrm{H}), 4.82(\mathrm{dd}, \mathrm{J}=12.0,72.9 \mathrm{~Hz}, 1 \mathrm{H}), 5.06(\mathrm{~d}, \mathrm{~J}=4.0 \mathrm{~Hz}$, $1 \mathrm{H}) ;{ }^{13} \mathrm{C}$ NMR $\left(100 \mathrm{MHz}, \mathrm{CDCl}_{3}\right) \delta 15.86,16.91,18.65,18.74,30.06,32.28,74.23,74.90$, $77.06,94.32,167.60,174.56$.

\section{Compound (24)}

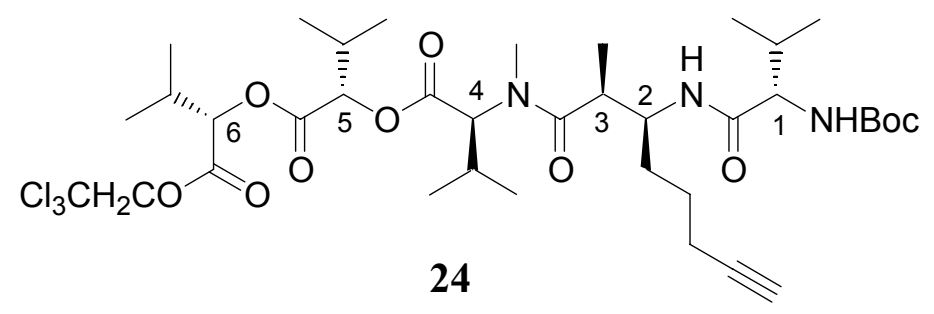

Solid lithium hydroxide monohydrate $(148 \mathrm{mg}, 3.54 \mathrm{mmol})$ was added in one portion to a stirred solution of acetylenic amide (20) $(175 \mathrm{mg}, 0.35 \mathrm{mmol})$ in THF/MeOH/water (2/2/1, 5 $\mathrm{mL}$ ) at $0^{\circ} \mathrm{C}$. After $1 \mathrm{~h}$, the reaction mixture was warmed to room temperature and stirred at that temperature for $5 \mathrm{~h}$. The volatile solvents were removed in vacuo and the aqueous phase was poured into diethyl ether $(15 \mathrm{~mL})$ and acidified to $\mathrm{pH} 2$ using dilute aqueous $\mathrm{KHSO}_{4}$ solution. The separated aqueous layer was extracted with ethyl acetate $(3 \times 50 \mathrm{~mL})$ and the combined organic extracts were washed with saturated $\mathrm{NaCl}$ solution $(20 \mathrm{~mL})$, dried $\left(\mathrm{Na}_{2} \mathrm{SO}_{4}\right)$ and evaporated in vacuo to give the corresponding acid (21) as a pale yellow oil which was used in the next reaction without further purification.

Dicyclohexylcarbodiimide (365 mg, $1.77 \mathrm{mmol}$ ) was added in one portion to a stirred mixture of the above acid, alcohol (22) (245 mg, $0.7 \mathrm{mmol})$, 4-dimethylaminopyridine (216 $\mathrm{mg}, 1.8 \mathrm{mmol})$ and (1R)-(-)-10-camphorsulfonic acid (16.4 $\mathrm{mg}, 0.07 \mathrm{mmol})$ in dry 
dichloromethane $(4 \mathrm{~mL})$ at $0^{\circ} \mathrm{C}$ and under an atmosphere of argon. The resulting mixture was stirred at $0^{\circ} \mathrm{C}$ for $2 \mathrm{~h}$ and then at room temperature overnight. The mixture was filtered through a pad of celite and the residue was washed with a mixture of hexanes and ethyl acetate $(1: 1,3 \times 5 \mathrm{~mL})$. The filtrate was evaporated in vacuo to leave a residue which was dissolved in ethyl acetate $(50 \mathrm{~mL})$ and washed with saturated $\mathrm{NH}_{4} \mathrm{Cl}$ solution $(5 \mathrm{~mL})$, saturated $\mathrm{NaCl}$ solution $(5 \mathrm{~mL})$, dried $\left(\mathrm{Na}_{2} \mathrm{SO}_{4}\right)$ and evaporated in vacuo to leave a pale yellow oil. The oil was purified by silica gel chromatography using $25 \%$ ethyl acetate hexane as eluent to give the corresponding ester (24) (205 mg, 70\%) as a colorless viscous oil; IR (neat) $v_{\max } 3311,2967,2935,2877,2126,1760,1714,1659,1500,1392,1368,1260,1177$, 1125, 1027, 870, 801, 757, 718 and $667 \mathrm{~cm}^{-1}$; $\mathrm{HRMS}(\mathrm{EI})$ for $\mathrm{C}_{37} \mathrm{H}_{60} \mathrm{Cl}_{3} \mathrm{~N}_{3} \mathrm{O}_{10}$ : Calcd 811.3344; Found 811.3337; (24): ${ }^{1} \mathrm{H}$ NMR (400 MHz, $\left.\mathrm{CDCl}_{3}\right) \delta 0.85(\mathrm{~d}, \mathrm{~J}=6.7 \mathrm{~Hz}, 3 \mathrm{H}), 0.90(\mathrm{~d}, \mathrm{~J}=6.9$ $\mathrm{Hz}, 3 \mathrm{H}), 1.00(\mathrm{~d}, \mathrm{~J}=6.8 \mathrm{~Hz}, 3 \mathrm{H}), 1.04-1.10(\mathrm{~m}, 12 \mathrm{H}), 1.17(\mathrm{~d}, \mathrm{~J}=7.1 \mathrm{~Hz}, 3 \mathrm{H}), 1.26-1.23$ $(\mathrm{m}, 3 \mathrm{H}), 1.43(\mathrm{~s}, 9 \mathrm{H}), 1.52-1.53(\mathrm{~m}, 4 \mathrm{H}), 1.91(\mathrm{t}, \mathrm{J}=2.5 \mathrm{~Hz}, 1 \mathrm{H}), 2.14-2.28(\mathrm{~m}, 4 \mathrm{H})$, $2.32-2.39(\mathrm{~m}, 2 \mathrm{H}), 2.94-2.97(\mathrm{~m}, 1 \mathrm{H}), 2.87,3.05(\mathrm{~s}, 3 \mathrm{H}), 3.97-4.07(\mathrm{~m}, 1 \mathrm{H}), 4.07-4.11$ $(\mathrm{m}, 1 \mathrm{H}), 4.81(\mathrm{dd}, \mathrm{J}=12.0,96.4 \mathrm{~Hz}, 2 \mathrm{H}), 4.96(\mathrm{~d}, \mathrm{~J}=4.0 \mathrm{~Hz}, 1 \mathrm{H}), 5.00(\mathrm{~d}, \mathrm{~J}=10.5 \mathrm{~Hz}, 1 \mathrm{H})$, $5.06(\mathrm{~d}, \mathrm{~J}=4.0 \mathrm{~Hz}, 2 \mathrm{H}), 7.75(\mathrm{~d}, \mathrm{~J}=9.5 \mathrm{~Hz}, 1 \mathrm{H}) ;{ }^{13} \mathrm{C} \mathrm{NMR}\left(100 \mathrm{MHz}, \mathrm{CDCl}_{3}\right) \delta 15.38,15.63$, $16.92,16.97,17.22,17.28,17.89,17.93,18.65,18.70,18.76,19.03,19.53,19.77,19.96$, $24.99,25.18,27.50,28.25$ (3C), 29.94, 30.01, 30.04, 30.66, 31.95, 32.30, 33.32, 33.40, 38.31, $38.81,51.47,51.71,60.01,60.31,61.03,65.82,68.57,68.66,74.18,76.76,76.79,76.87$, $79.48,83.92,84.07,94.29,155.64,167.50,167.60,168.44,168.74,169.44,170.25,171.67$, $176.67,176.71$

The isomer $\mathbf{2 4 a}$ was synthesized according to the above procedures from $\mathbf{2 0 a}$

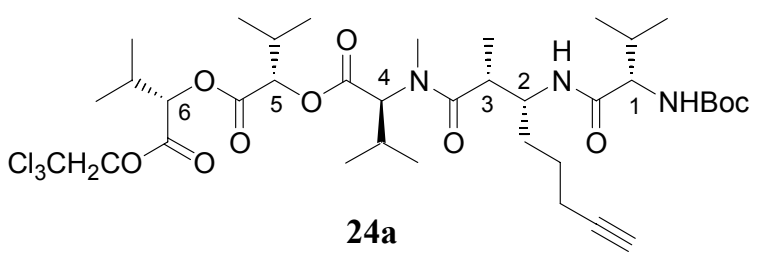

$(2 \mathrm{R}, 3 \mathrm{R})-(\mathbf{2 4 a}):[\alpha]_{\mathrm{D}}{ }^{20}-58.4\left(\mathrm{c}=1.46, \mathrm{CHCl}_{3}\right)$;

${ }^{1} \mathrm{H}$ NMR $\left(400 \mathrm{MHz}, \mathrm{CDCl}_{3}\right) \delta 0.91(\mathrm{~d}, \mathrm{~J}=6.9 \mathrm{~Hz}, 6 \mathrm{H}), 0.98(\mathrm{~d}, \mathrm{~J}=6.8 \mathrm{~Hz}, 3 \mathrm{H}), 1.04-1.12$ 
$(\mathrm{m}, 15 \mathrm{H}), 1.16(\mathrm{~d}, \mathrm{~J}=7.1 \mathrm{~Hz}, 3 \mathrm{H}), 1.44(\mathrm{~s}, 9 \mathrm{H}), 1.49-1.60(\mathrm{~m}, 4 \mathrm{H}), 1.90(\mathrm{t}, \mathrm{J}=2.6 \mathrm{~Hz}, 1 \mathrm{H})$, $2.09-2.29(\mathrm{~m}, 4 \mathrm{H}), 2.33-2.41(\mathrm{~m}, 2 \mathrm{H}), 2.96(\mathrm{dq}, \mathrm{J}=3.4,7.0 \mathrm{~Hz}, 1 \mathrm{H}), 2.95,3.06(\mathrm{~s}, 3 \mathrm{H})$, $3.99-4.04(\mathrm{~m}, 1 \mathrm{H}), 4.06-4.08(\mathrm{~m}, 1 \mathrm{H}), 4.80(\mathrm{dd}, \mathrm{J}=12.0,92.7 \mathrm{~Hz}, 2 \mathrm{H}), 4.95(\mathrm{~d}, \mathrm{~J}=4.1 \mathrm{~Hz}$, 1H), $5.05(\mathrm{~d}, \mathrm{~J}=4.0 \mathrm{~Hz}, 1 \mathrm{H}), 5.06(\mathrm{~d}, \mathrm{~J}=10.3 \mathrm{~Hz}, 1 \mathrm{H}), 5.16(\mathrm{~d}, \mathrm{~J}=8.3 \mathrm{~Hz}, 1 \mathrm{H}), 7.67$ (d, J = $9.1 \mathrm{~Hz}, 1 \mathrm{H}) ;{ }^{13} \mathrm{C} \mathrm{NMR}\left(100 \mathrm{MHz}, \mathrm{CDCl}_{3}\right) \delta 14.93,15.99,17.02,17.22,17.52,17.98,18.05$, $18.66,18.69,18.77,19.27,19.33,19.43,19.57,19.73,25.17,25.23,27.29,28.21,28.31(3 \mathrm{C})$ $30.03,30.10,30.13,31.05,31.15,31.81,33.18,33.37,38.07,38.24,51.41,51.91,59.96$, $61.08,66.17,68.54,68.68,74.27,76.89,76.93,79.48,83.82,94.36,155.74,167.52,167.66$, $168.34,168.81,169.72,170.44,171.68,176.68,176.86$.

\section{Compound (25)}

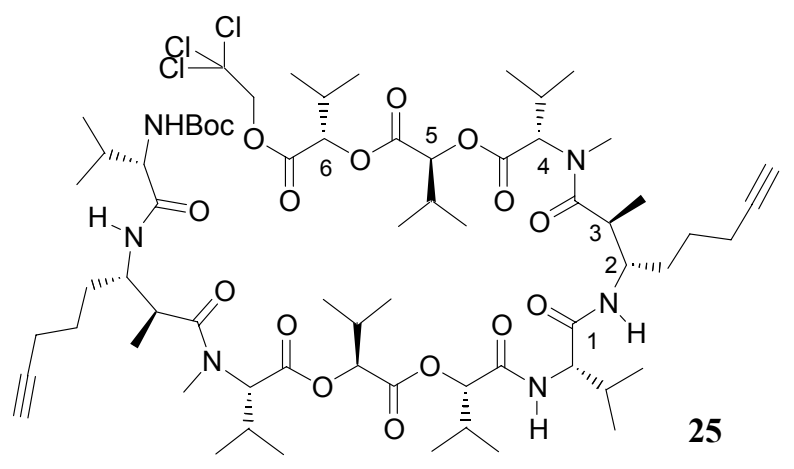

Zinc powder (81 mg, $1.24 \mathrm{mmol})$ was added in three portions to a stirred solution of ester (24) $(26.8 \mathrm{mg}, 0.034 \mathrm{mmol})$ in THF $(1.5 \mathrm{~mL})$ under an atmosphere of argon and then $1 \mathrm{~N}$ $\mathrm{NH}_{4} \mathrm{OAc}$ solution $(0.2 \mathrm{~mL})$ was added. The reaction mixture was stirred at room temperature overnight and filtered through a pad of celite. The residue was washed with ethyl acetate $(3 \times 5 \mathrm{~mL})$ and the combined filtrates were diluted with ethyl acetate $(25 \mathrm{~mL})$, washed with dilute $\mathrm{KHSO}_{4}$ solution $(2 \times 5 \mathrm{~mL})$, saturated $\mathrm{NaCl}$ solution $(10 \mathrm{~mL})$, dried $\left(\mathrm{Na}_{2} \mathrm{SO}_{4}\right)$ and evaporated in vacuo to give acid (3) (19 $\mathrm{mg}, 81 \%)$ as a pale yellow oil which was used in the next reaction without further purification.

Trifluoroacetic acid (2 mL) was added dropwise to a stirred solution of ester (24) (25.7 $\mathrm{mg}, 0.03 \mathrm{mmol})$ in dry dichloromethane $(2 \mathrm{~mL})$ at $0^{\circ} \mathrm{C}$ and under an atmosphere of argon. The resulting mixture was stirred at $0^{\circ} \mathrm{C}$ for $16 \mathrm{~h}$. The reaction mixture was poured into a mixture of benzene and chloroform $(1: 1,10 \mathrm{~mL})$ and evaporated in vacuo to give amine (2) as a brown residue which was used in the next reaction without further purification. 
1-(3-dimethylaminopropyl)-3-ethylcarbodiimide hydrochloride (132 $\mathrm{mg}, 0.69 \mathrm{mmol}$ ) was added in one portion to a stirred mixture of acid (3) (19 mg, $0.027 \mathrm{mmol}$ ), amine (2), 1-hydroxybenzotriazole $(93 \mathrm{mg}, 0.69 \mathrm{mmol})$ and diisopropylethylamine $(0.26 \mathrm{ml}, 15 \mathrm{mmol})$ in dry dichloromethane $(1 \mathrm{~mL})$ at $0^{\circ} \mathrm{C}$ and under an atmosphere of argon. The resulting mixture was stirred at $0^{\circ} \mathrm{C}$ for $2 \mathrm{~h}$ and stirred at room temperature overnight. The mixture was dissolved in ethyl acetate $(20 \mathrm{~mL})$ and washed with saturated $\mathrm{NH}_{4} \mathrm{Cl}$ solution $(5 \mathrm{~mL})$ and saturated $\mathrm{NaCl}$ solution $(5 \mathrm{~mL})$. The organic layer was dried $\left(\mathrm{Na}_{2} \mathrm{SO}_{4}\right)$ and evaporated in vacuo to leave a yellow oil. The oil was purified by silica gel chromatography using $1 \%$ methanol - chloroform as eluent to give the amide $(21 \mathrm{mg}, 53 \%)$ as a colorless viscous oil; IR (neat); $v_{\max } 3311,2967,2935,2876,2118,1743,1650,1505,1468,1411,1391,1370,1279$, 1181, 1126, 1026, 756, 718 and $665 \mathrm{~cm}^{-1}$; Precursor (25): $[\alpha]_{\mathrm{D}}{ }^{20}-71.7(\mathrm{c}=1.41, \mathrm{EA}) ;{ }^{1} \mathrm{H}$ NMR (400 MHz, $\left.\mathrm{CDCl}_{3}\right) \delta 0.85(\mathrm{~d}, \mathrm{~J}=6.9 \mathrm{~Hz}, 3 \mathrm{H}), 0.87(\mathrm{~d}, \mathrm{~J}=6.8 \mathrm{~Hz}, 3 \mathrm{H}), 0.90(\mathrm{~d}, \mathrm{~J}=6.9$ $\mathrm{Hz}, 3 \mathrm{H}), 0.93-1.00(\mathrm{~m}, 18 \mathrm{H}), 1.04-1.10(\mathrm{~m}, 18 \mathrm{H}), 1.16-1.18(\mathrm{~m}, 6 \mathrm{H}), 1.24(\mathrm{~d}, \mathrm{~J}=7.5 \mathrm{~Hz}$, 3H), $1.43(\mathrm{~s}, 9 \mathrm{H}), 1.47-1.58(\mathrm{~m}, 8 \mathrm{H}), 1.89-1.91(\mathrm{~m}, 1 \mathrm{H}), 1.94(\mathrm{t}, \mathrm{J}=2.5 \mathrm{~Hz}, 1 \mathrm{H}), 2.10-$ $2.41(\mathrm{~m}, 12 \mathrm{H}), 2.93-3.00(\mathrm{~m}, 2 \mathrm{H}), 2.86,3.03(\mathrm{~s}, 3 \mathrm{H}), 2.87,3.06(\mathrm{~s}, 3 \mathrm{H}), 3.97-4.12(\mathrm{~m}, 3 \mathrm{H})$, $4.34(\mathrm{dd}, \mathrm{J}=5.3,8.4 \mathrm{~Hz}, 1 \mathrm{H}), 4.69(\mathrm{~d}, \mathrm{~J}=12.0 \mathrm{~Hz}, 1 \mathrm{H}), 4.90-4.96(\mathrm{~m}, 4 \mathrm{H}), 5.01-5.08(\mathrm{~m}$, 4H), $6.70(\mathrm{~d}, \mathrm{~J}=8.6 \mathrm{~Hz}, 1 \mathrm{H}), 7.56(\mathrm{~d}, \mathrm{~J}=9.4 \mathrm{~Hz}, 1 \mathrm{H}), 7.74(\mathrm{~d}, \mathrm{~J}=9.3 \mathrm{~Hz}, 1 \mathrm{H}), 7.80(\mathrm{~d}, \mathrm{~J}=$ $9.4 \mathrm{~Hz}) ;{ }^{13} \mathrm{C} \mathrm{NMR}\left(100 \mathrm{MHz}, \mathrm{CDCl}_{3}\right) \delta 15.36,15.43,15.53,15.62,16.97,17.00,17.15,17.26$, $17.66,17.68,17.89,17.93,17.97,18.62,18.68,18.76,18.80,18.92,19.06,19.25,19.39$, $19.56,19.64,19.76,19.95,22.76,24.94,25.04,25.11,25.19,27.46,27.57,27.94,28.29$, 28.32 (3C), 29.07, 29.66, 29.92, 29.97, 30.06, 30.08, 30.64, 30.68, 31.23, 31.27, 31.57, 31.69, $31.96,32.10,33.13,33.25,33.32,33.40,38.19,38.24,38.45,38.67,51.12,51.50,51.61$, $51.73,51.78,51.82,58.27,58.40,60.06,60.98,61.29,61.84,65.88,68.60,68.66,68.69$, $74.22,76.81,76.84,77.20,77.84,79.20,79.29,79.55,83.88,83.94,84.02,84.12,94.32$, $155.69,167.55,167.64,168.00,168.26,168.37,168.50,168.79,169.44,169.70,170.22$, $170.26,170.38,170.44,170.68,171.74,176.52,176.59,176.77$ 
The isomer 25a was synthesized according to the above procedures from 24a

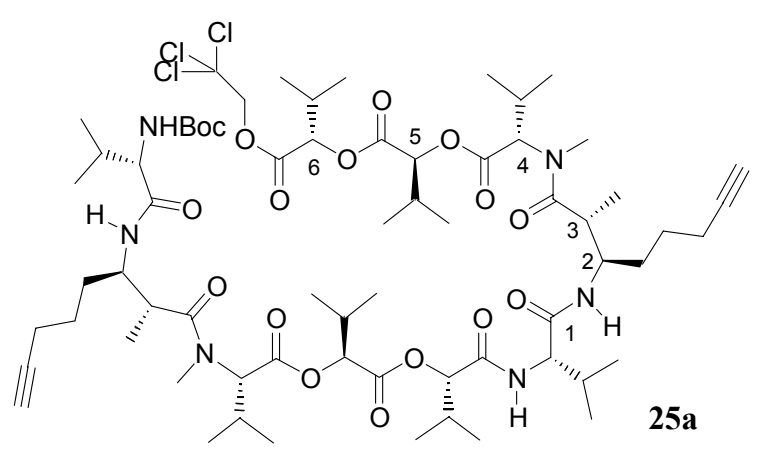

Precursor (25a): $[\alpha]_{D}{ }^{20}-70.7(\mathrm{c}=0.40$, $\left.\mathrm{CHCl}_{3}\right) ;{ }^{1} \mathrm{H} \mathrm{NMR}\left(600 \mathrm{MHz}, \mathrm{CDCl}_{3}\right) \delta 0.91(\mathrm{~d}$, $\mathrm{J}=6.5 \mathrm{~Hz}, 3 \mathrm{H}), 0.92(\mathrm{~d}, \mathrm{~J}=6.7 \mathrm{~Hz}, 3 \mathrm{H})$, $0.99-0.99(\mathrm{~m}, 18 \mathrm{H}), 1.03-1.11(\mathrm{~m}, 27 \mathrm{H})$ $1.16(\mathrm{~d}, \mathrm{~J}=7.0 \mathrm{~Hz}, 3 \mathrm{H}), 1.44(\mathrm{~s}, 9 \mathrm{H}), 1.51-$ $1.58(\mathrm{~m}, 8 \mathrm{H}), 1.90(\mathrm{t}, \mathrm{J}=2.6 \mathrm{~Hz}, 2 \mathrm{H}), 1.97(\mathrm{t}, \mathrm{J}$ $=2.6 \mathrm{~Hz}), 2.12-2.42(\mathrm{~m}, 12 \mathrm{H}), 2.94-2.98(\mathrm{~m}, 2 \mathrm{H}), 2.92,3.04(\mathrm{~s}, 3 \mathrm{H}), 2.93,3.05(\mathrm{~s}, 3 \mathrm{H})$, $3.95-4.10(\mathrm{~m}, 3 \mathrm{H}), 4.33(\mathrm{dd}, \mathrm{J}=5.6,8.4 \mathrm{~Hz}, 1 \mathrm{H}), 4.80(\mathrm{dd}, \mathrm{J}=12.0,134.4 \mathrm{~Hz}, 1 \mathrm{H}), 4.94(\mathrm{~d}$, $\mathrm{J}=4.1 \mathrm{~Hz}, 1 \mathrm{H}), 4.96(\mathrm{~d}, \mathrm{~J}=4.0 \mathrm{~Hz}, 1 \mathrm{H}), 5.01-5.04(\mathrm{~m}, 3 \mathrm{H}), 5.09(\mathrm{~d}, \mathrm{~J}=10.5 \mathrm{~Hz}, 1 \mathrm{H}), 5.14$ $(\mathrm{d}, \mathrm{J}=7.6 \mathrm{~Hz}, 1 \mathrm{H}), 6.70(\mathrm{~d}, \mathrm{~J}=8.4 \mathrm{~Hz}, 1 \mathrm{H}), 7.52(\mathrm{~d}, \mathrm{~J}=9.3 \mathrm{~Hz}, 1 \mathrm{H}), 7.57(\mathrm{~d}, \mathrm{~J}=9.4 \mathrm{~Hz})$, $7.60(\mathrm{~d}, \mathrm{~J}=9.5 \mathrm{~Hz}), 7.65(\mathrm{~d}, \mathrm{~J}=9.1 \mathrm{~Hz}, 1 \mathrm{H}) ;{ }^{13} \mathrm{C} \mathrm{NMR}\left(150 \mathrm{MHz}, \mathrm{CDCl}_{3}\right) \delta 14.65,14.82$, $14.95,15.75,16.93,17.01,17.04,17.21,17.23,17.52,17.98,18.05,18.54,18.67,18.70$, $18.76,18.96,19.04,19.19,19.23,19.28,19.34,19.44,19.56,19.70,19.89,23.82,25.17$, $25.25,27.17,27.29,28.31$ (3C), 29.33, 29.68, 29.92, 30.01, 30.10, 30.13, 30.55, 31.17, 31.41, $31.77,33.05,33.36,38.04,38.10,51.42,51.48,58.38,58.56,59.95,61.00,61.07,66.15$, $68.69,68.72,74.26,76.88,76.95,77.39,79.33,79.47,83.74,83.82,94.36,155.71,167.38$, $167.66,168.32,168.40,168.47,168.81,169.70,170.42,170.46,170.85,171.66,176.50$, 176.59 .

\section{Onchidin (1) \& (1a)}

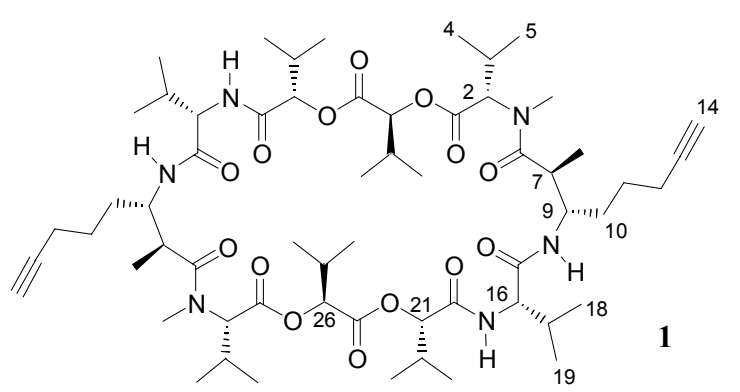

Zinc powder (81 $\mathrm{mg}, 1.24 \mathrm{mmol})$ was added in three portions to a stirred solution of the amide (25) $(21 \mathrm{mg}, 0.0147 \mathrm{mmol})$ in THF $(1.5 \mathrm{~mL})$ under an atmosphere of argon and then $1 \mathrm{~N}$ $\mathrm{NH}_{4} \mathrm{OAc}(0.2 \mathrm{~mL})$ was added. The reaction mixture was stirred at room temperature overnight and filtered through a pad of celite. The 
residue was washed with ethyl acetate $(3 \times 5 \mathrm{~mL})$ and the combined filtrates were diluted by ethyl acetate $(25 \mathrm{~mL})$, washed by dilute $\mathrm{KHSO}_{4}$ solution $(2 \times 5 \mathrm{~mL})$, saturated $\mathrm{NaCl}$ solution $(5$ $\mathrm{mL})$, dried $\left(\mathrm{Na}_{2} \mathrm{SO}_{4}\right)$ and evaporated in vacuo to give the crude acid as a pale yellow oil which was used in the next reaction without further purification.

Trifluoroacetic acid $(2 \mathrm{~mL})$ was added dropwise to a stirred solution of the crude acid in dry dichloromethane $(2 \mathrm{~mL})$ at $0^{\circ} \mathrm{C}$ and under an atmosphere of argon. The resulting mixture was stirred at $0^{\circ} \mathrm{C}$ for $16 \mathrm{~h}$. The reaction mixture was poured into a mixture of benzene and chloroform $(1: 1,10 \mathrm{~mL})$ and evaporated in vacuo. The crude product was dissolved in dry DMF $(30 \mathrm{~mL})$. To this solution was added diisopropylethylamine $(83 \mu \mathrm{L}, 0.48 \mathrm{mmol})$ and pentafluorophenyl diphenylphosphinate $(101.4 \mathrm{mg}, 0.24 \mathrm{mmol})$ at room temperature and under an atmosphere of argon. The resulting mixture was stirred at room temperature for 4 days. The solvent was evaporated in vacuo to leave a yellow residue, which was dissolved in ethyl acetate $(30 \mathrm{~mL})$ and washed with saturated $\mathrm{NH}_{4} \mathrm{Cl}$ solution $(5 \mathrm{~mL})$, saturated $\mathrm{NaHCO}_{3}$ solution $(5 \mathrm{~mL})$ and saturated $\mathrm{NaCl}$ solution $(5 \mathrm{~mL})$. The organic layer was dried $\left(\mathrm{Na}_{2} \mathrm{SO}_{4}\right)$ and evaporated in vacuo to leave a brown residue. The residue was purified by silica gel chromatography using $1 \%$ methanol - chloroform as eluent to give (1) $(8.7 \mathrm{mg}, 62.4 \%)$ as a colorless oil; IR (neat) $v_{\max } 3449,3313,2966,2876,2126,1776,1744,1678,1633,1519$, $1500,1473,1414,1392,1372,1302,1189,1125,1030,1002,755$ and $665 \mathrm{~cm}^{-1}$; HRMS(FAB) for $\mathrm{C}_{60} \mathrm{H}_{99} \mathrm{~N}_{6} \mathrm{O}_{14}(\mathrm{M}+1)$ : Calcd 1127.722; Found 1127.720; $(\mathbf{1}):[\alpha]_{\mathrm{D}}{ }^{20}-95.5(\mathrm{c}=0.58$, $\left.\mathrm{CHCl}_{3}\right) ;{ }^{1} \mathrm{H}$ NMR $\left(500 \mathrm{MHz}, \mathrm{CDCl}_{3}\right) \delta 0.81(\mathrm{~d}, \mathrm{~J}=6.7 \mathrm{~Hz}, 3 \mathrm{H}), 0.91(\mathrm{~d}, \mathrm{~J}=7.0 \mathrm{~Hz}, 3 \mathrm{H}), 0.93$ $(\mathrm{d}, \mathrm{J}=6.9 \mathrm{~Hz}, 3 \mathrm{H}), 0.97(\mathrm{~d}, \mathrm{~J}=7.0 \mathrm{~Hz}, 3 \mathrm{H}), 1.01(\mathrm{~d}, \mathrm{~J}=6.8 \mathrm{~Hz}, 3 \mathrm{H}), 1.04$ (d, J $6.9 \mathrm{~Hz}, 6 \mathrm{H})$, $1.07(\mathrm{~d}, \mathrm{~J}=6.4 \mathrm{~Hz}, 3 \mathrm{H}), 1.15(\mathrm{~d}, \mathrm{~J}=7.2 \mathrm{~Hz}, 3 \mathrm{H}), 1.37-1.42(\mathrm{~m}, 1 \mathrm{H}), 1.47-1.52(\mathrm{~m}, 2 \mathrm{H})$, $1.53-1.57(\mathrm{~m}, 1 \mathrm{H}), 1.88(\mathrm{t}, \mathrm{J}=2.6 \mathrm{~Hz}, 1 \mathrm{H}), 2.07-2.12(\mathrm{~m}, 1 \mathrm{H}), 2.14-2.20(\mathrm{~m}, 2 \mathrm{H}), 2.40$ $(\mathrm{dq}, \mathrm{J}=2.8,6.8 \mathrm{~Hz}, 1 \mathrm{H}), 2.46(\mathrm{dq}, \mathrm{J}=2.9,6.8 \mathrm{~Hz}, 1 \mathrm{H}), 2.63(\mathrm{dq}, \mathrm{J}=3.3,7.0 \mathrm{~Hz}, 1 \mathrm{H}), 2.76$ $(\mathrm{dq}, \mathrm{J}=2.5,7.2 \mathrm{~Hz}, 1 \mathrm{H}), 2.86(\mathrm{~s}, 3 \mathrm{H}), 3.92(\mathrm{t}, \mathrm{J}=9.4 \mathrm{~Hz}, 1 \mathrm{H}), 4.42(\mathrm{dd}, \mathrm{J}=3.3,8.2 \mathrm{~Hz}, 1 \mathrm{H})$, $5.22(\mathrm{~d}, \mathrm{~J}=2.9 \mathrm{~Hz}, 1 \mathrm{H}), 5.33(\mathrm{~d}, \mathrm{~J}=11.2 \mathrm{~Hz}, 1 \mathrm{H}), 5.60(\mathrm{~d}, \mathrm{~J}=2.8 \mathrm{~Hz}, 1 \mathrm{H}), 6.37(\mathrm{~d}, \mathrm{~J}=8.3$ 
$\mathrm{Hz}, 1 \mathrm{H}), 8.98(\mathrm{~d}, \mathrm{~J}=9.2 \mathrm{~Hz}, 1 \mathrm{H}) ;{ }^{13} \mathrm{C} \mathrm{NMR}\left(125 \mathrm{MHz}, \mathrm{CDCl}_{3}\right) \delta 15.37,16.14,16.45,16.50$, $17.64,18.08,18.75,19.06,19.52,20.01,25.55,26.64,28.09,30.05,30.16,31.18,34.05$, $39.00,52.33,58.69,59.72,68.71,75.34,78.33,83.83,165.27,169.74,170.54,170.66,176.37$ The isomer 1a was synthesized according to the above procedures from 25a

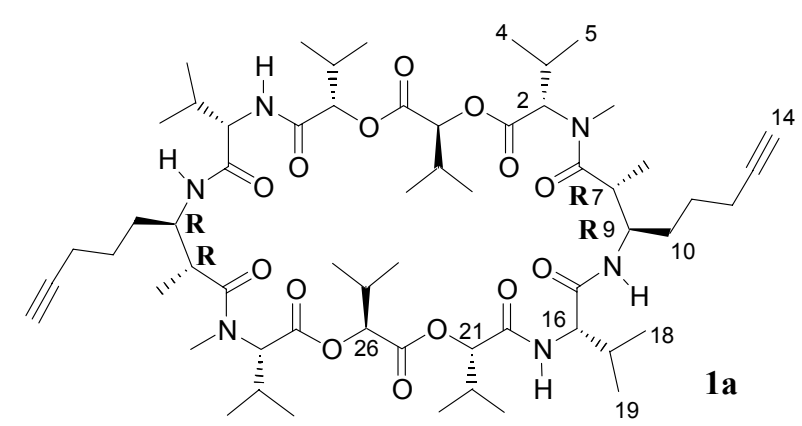
(1a): $[\alpha]_{\mathrm{D}}{ }^{20}-81.5\left(\mathrm{c}=0.40, \mathrm{CHCl}_{3}\right) ;{ }^{1} \mathrm{H}$ NMR $\left(600 \mathrm{MHz}, \mathrm{CDCl}_{3}\right) \delta 0.91(\mathrm{~d}, \mathrm{~J}=6.7$ $\mathrm{Hz}, 6 \mathrm{H}), 0.95(\mathrm{~d}, \mathrm{~J}=6.9 \mathrm{~Hz}, 3 \mathrm{H}), 0.96-0.98$ (m, 6H), $0.99(\mathrm{~d}, \mathrm{~J}=7.0 \mathrm{~Hz}, 3 \mathrm{H}), 1.04(\mathrm{~d}, \mathrm{~J}$ $6.9 \mathrm{~Hz}, 3 \mathrm{H}), 1.10(\mathrm{~d}, \mathrm{~J}=6.4 \mathrm{~Hz}, 3 \mathrm{H}), 1.11(\mathrm{~d}$, $\mathrm{J}=6.9 \mathrm{~Hz}, 3 \mathrm{H}), 1.48(\mathrm{dq}, \mathrm{J}=3.6,6.7 \mathrm{~Hz}, 1 \mathrm{H}), 1.50-1.58(\mathrm{~m}, 3 \mathrm{H}), 1.90(\mathrm{t}, \mathrm{J}=2.6 \mathrm{~Hz}, 1 \mathrm{H})$, $2.12-2.18(\mathrm{~m}, 1 \mathrm{H}), 2.20-2.27(\mathrm{~m}, 2 \mathrm{H}), 2.30-2.38(\mathrm{~m}, 2 \mathrm{H}), 2.38-2.44(\mathrm{~m}, 1 \mathrm{H}), 2.89(\mathrm{dq}$ $\mathrm{J}=3.2,7.0 \mathrm{~Hz}, 1 \mathrm{H}), 2.97(\mathrm{~s}, 3 \mathrm{H}), 4.03-4.06(\mathrm{~m}, 1 \mathrm{H}), 4.39(\mathrm{dd}, \mathrm{J}=5.4,8.6 \mathrm{~Hz}, 1 \mathrm{H}), 5.13(\mathrm{~d}$, $\mathrm{J}=4.6 \mathrm{~Hz}, 1 \mathrm{H}), 5.15(\mathrm{~d}, \mathrm{~J}=10.6 \mathrm{~Hz}, 1 \mathrm{H}), 5.32(\mathrm{~d}, \mathrm{~J}=3.1 \mathrm{~Hz}, 1 \mathrm{H}), 6.68(\mathrm{~d}, \mathrm{~J}=8.5 \mathrm{~Hz}, 1 \mathrm{H})$, $7.43-7.45(\mathrm{br}, 1 \mathrm{H}) ;{ }^{13} \mathrm{C} \mathrm{NMR}\left(150 \mathrm{MHz}, \mathrm{CDCl}_{3}\right) \delta 14.50,16.73,17.20,17.62,17.91,18.67$, $19.10,19.27,19.53,19.94,24.97,26.66,29.25,30.34(2 \mathrm{C}), 31.19,32.08,38.61,51.09,58.88$, $60.87,68.62,76.93,79.70,84.08,168.27,169.60,170.55,170.79,175.70$. 


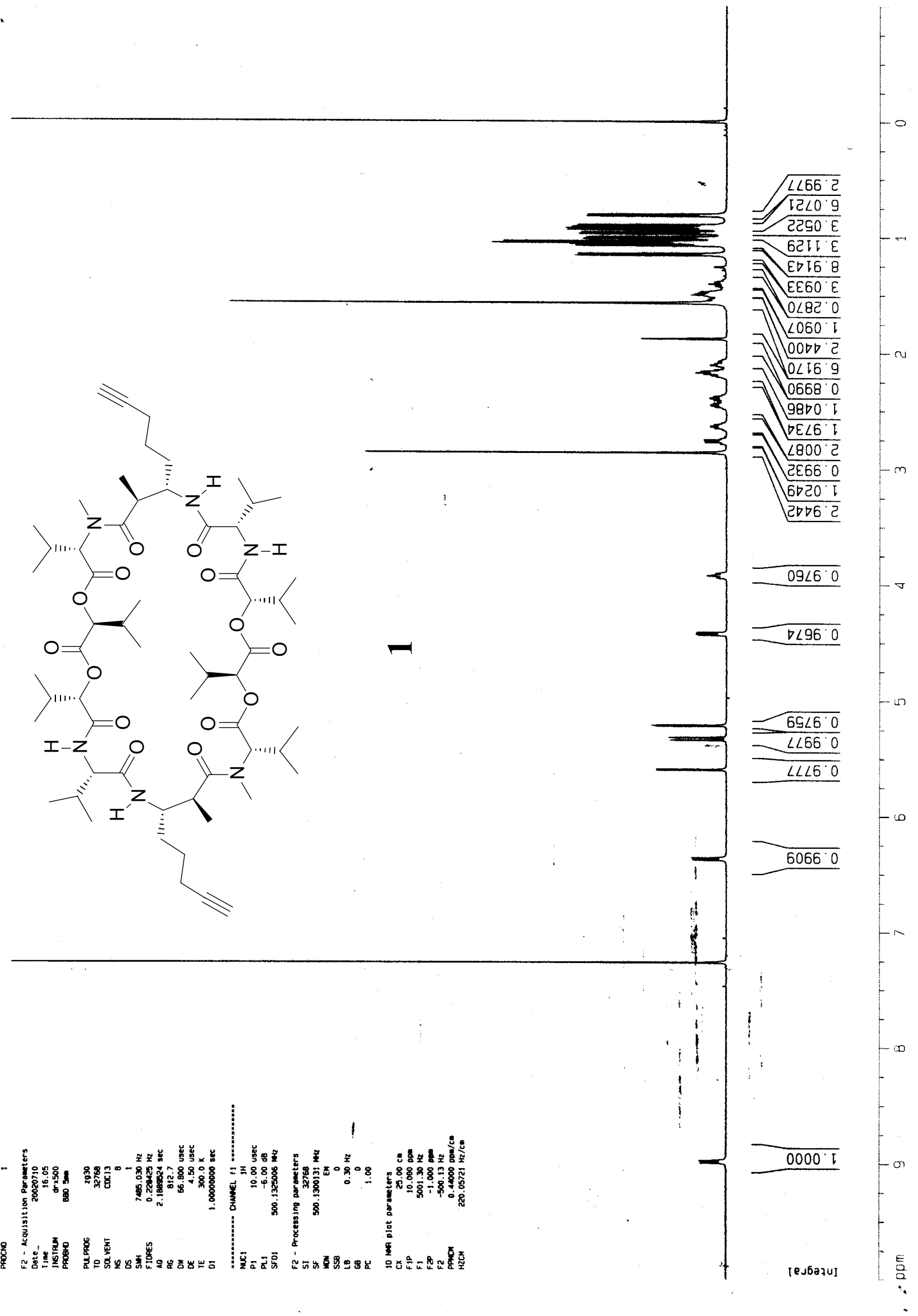




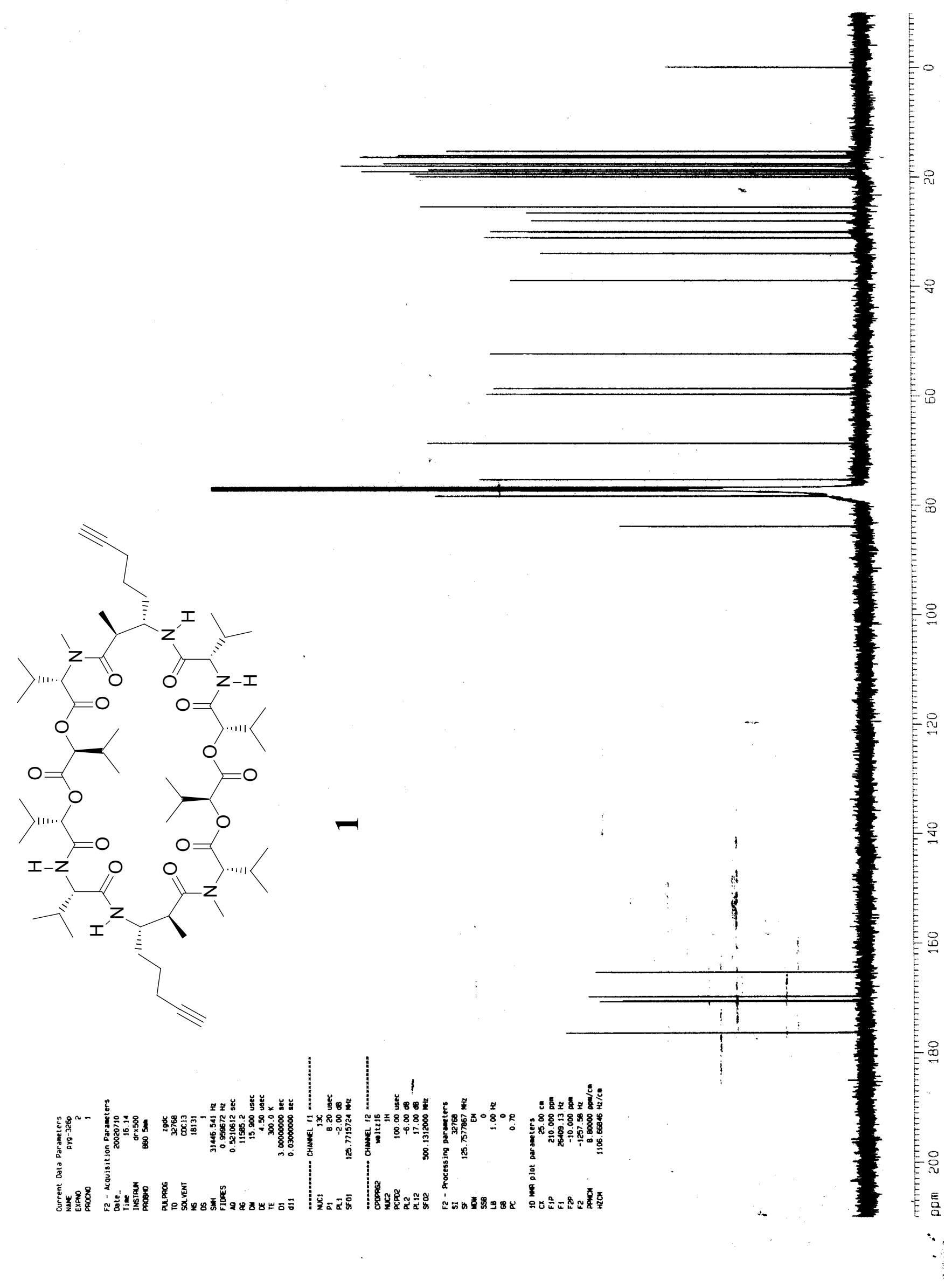




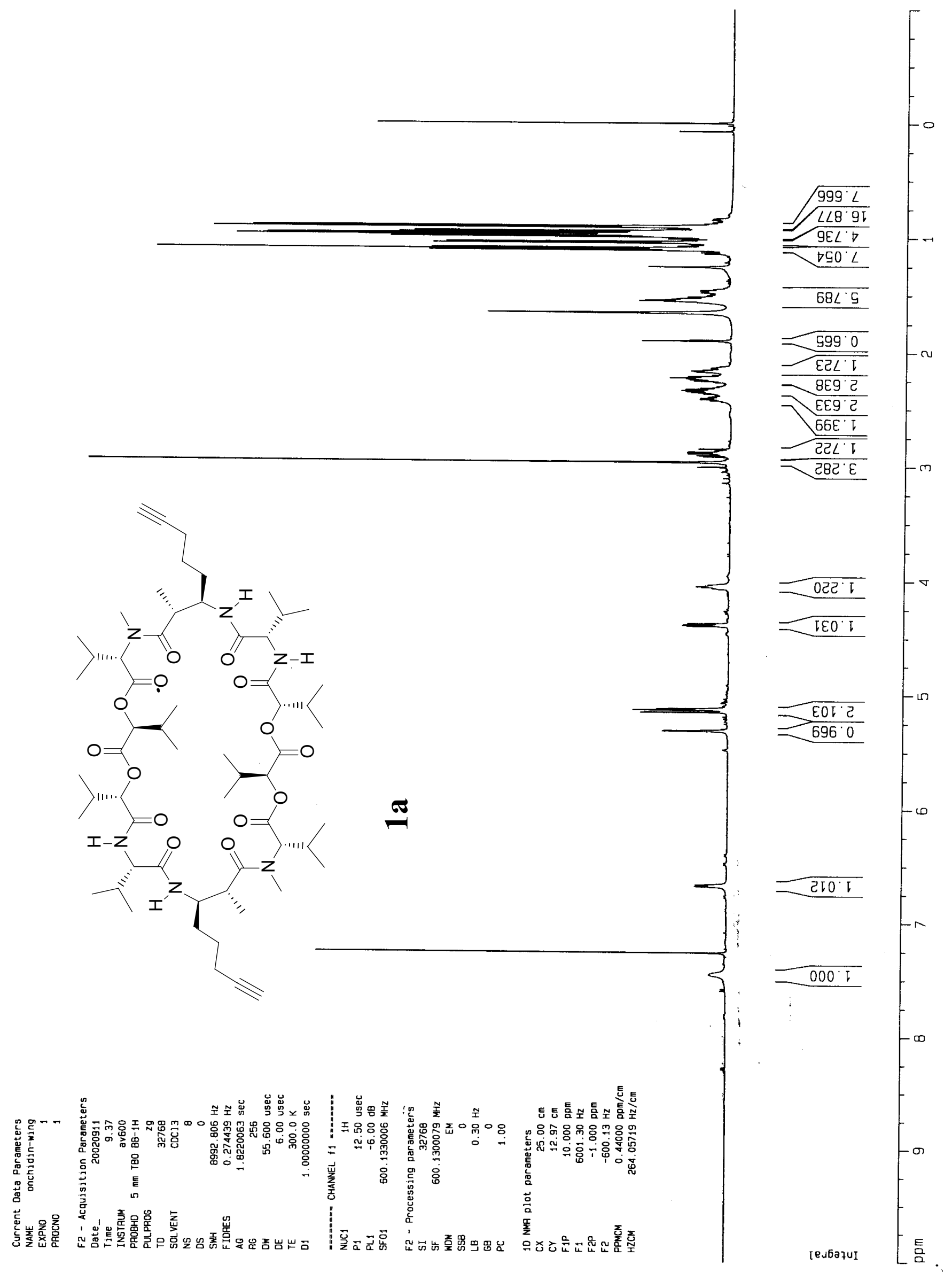




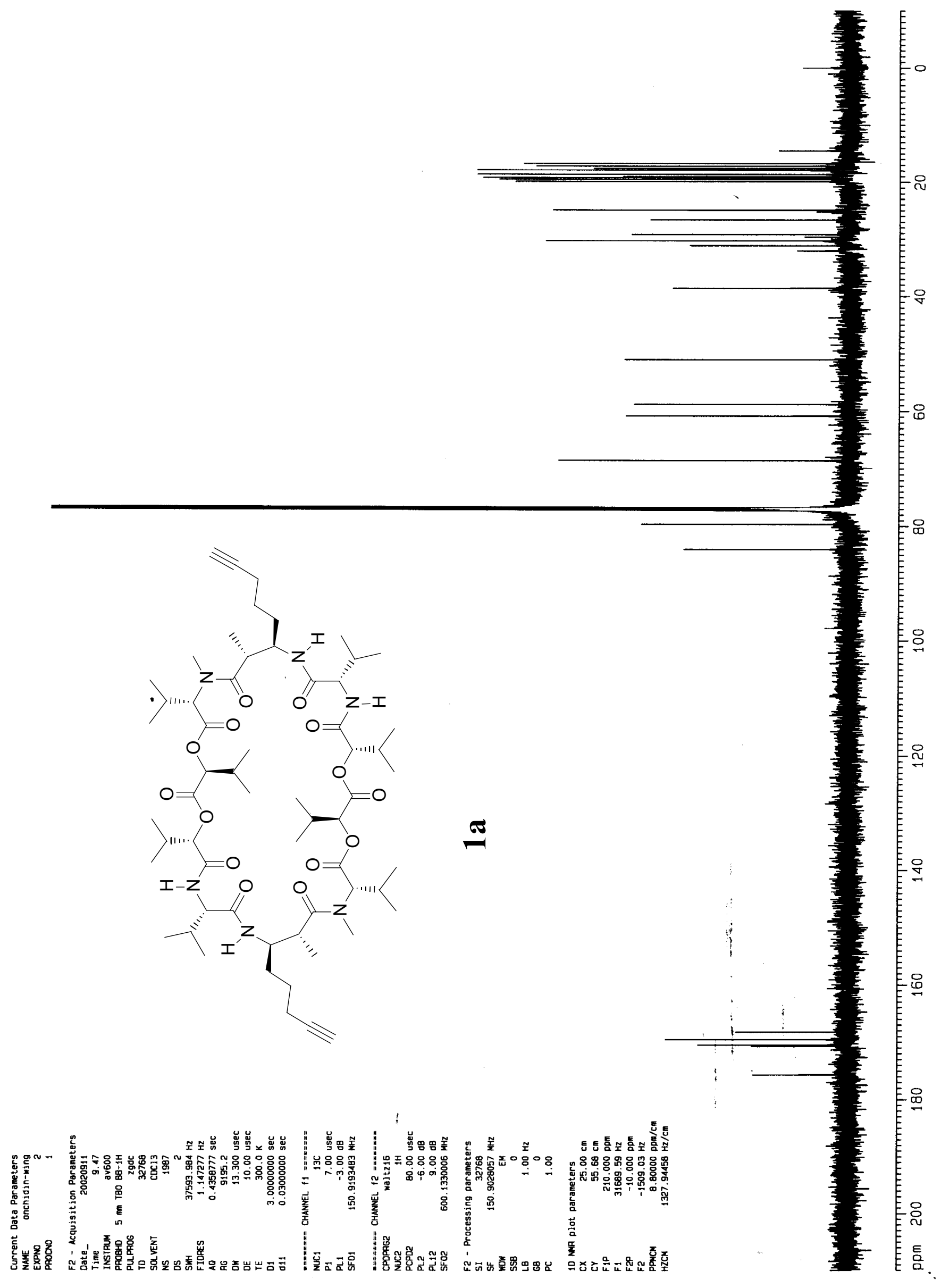




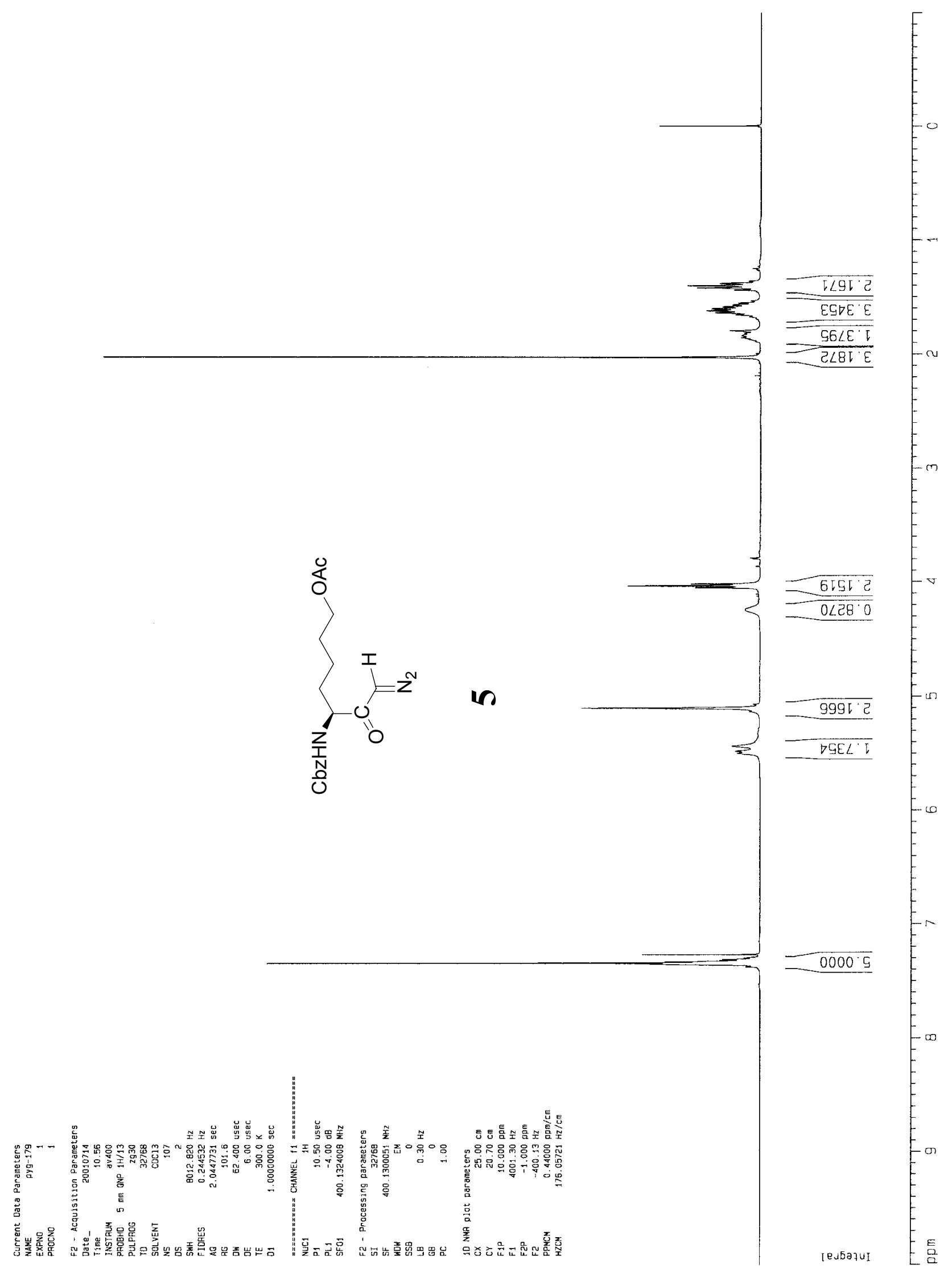


$888^{\circ} 0 \mathrm{C}-$
$\nabla \circ 9^{\circ} \mathrm{Ic}=$

$80 \mathrm{c}^{\prime} 8 \mathrm{z}$

ट90. टह

$\nabla 90^{\circ} \nabla 5$

GE $\angle 9$

$\angle S B^{\circ} E 9$

โ $0 . \angle 9$

289. 94

$000 \% \angle$

BLE LL

ơ

920821

98: 8ट ए

680 821

BO ' 98 I

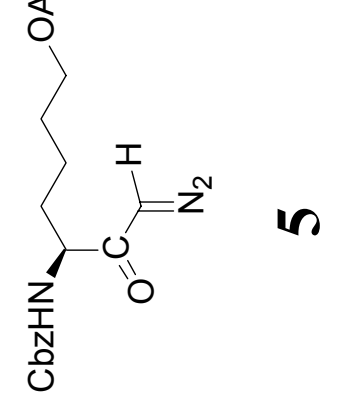

จTE'GSโ—

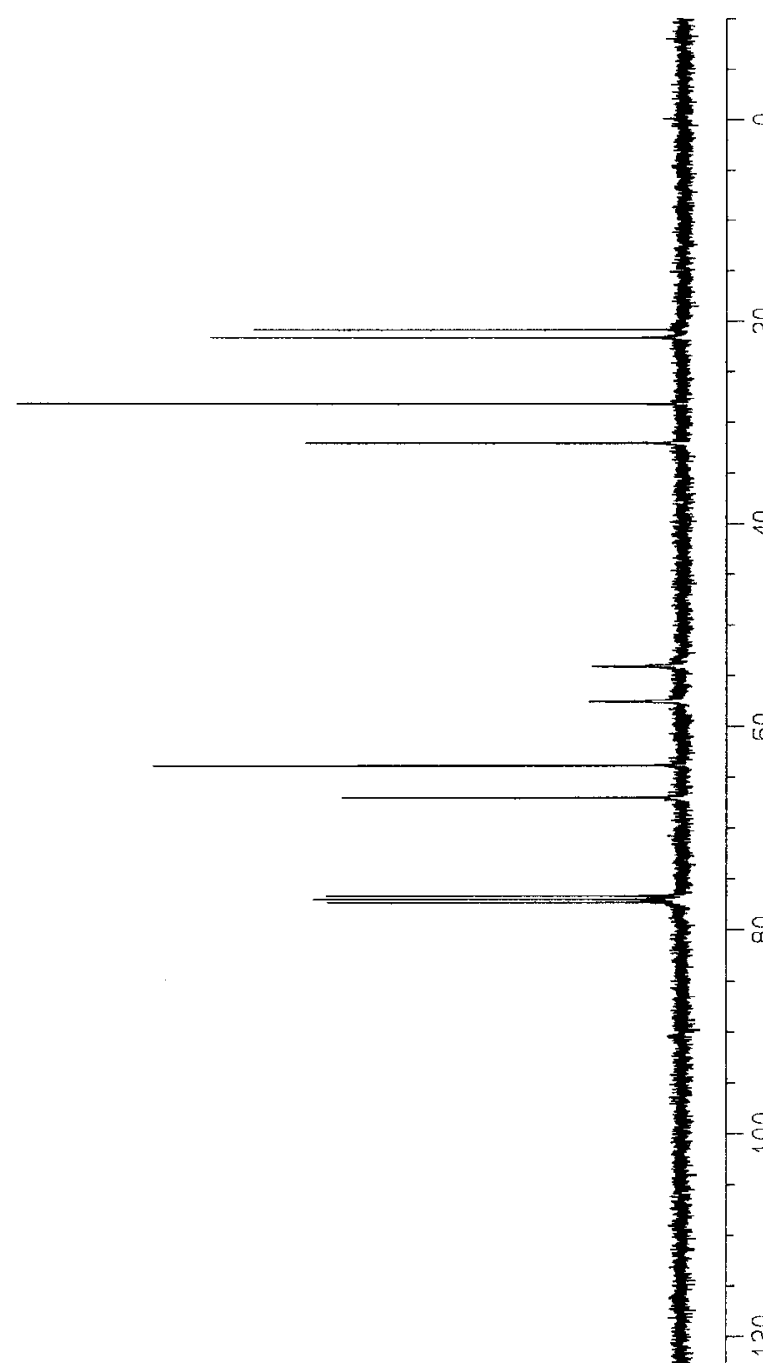




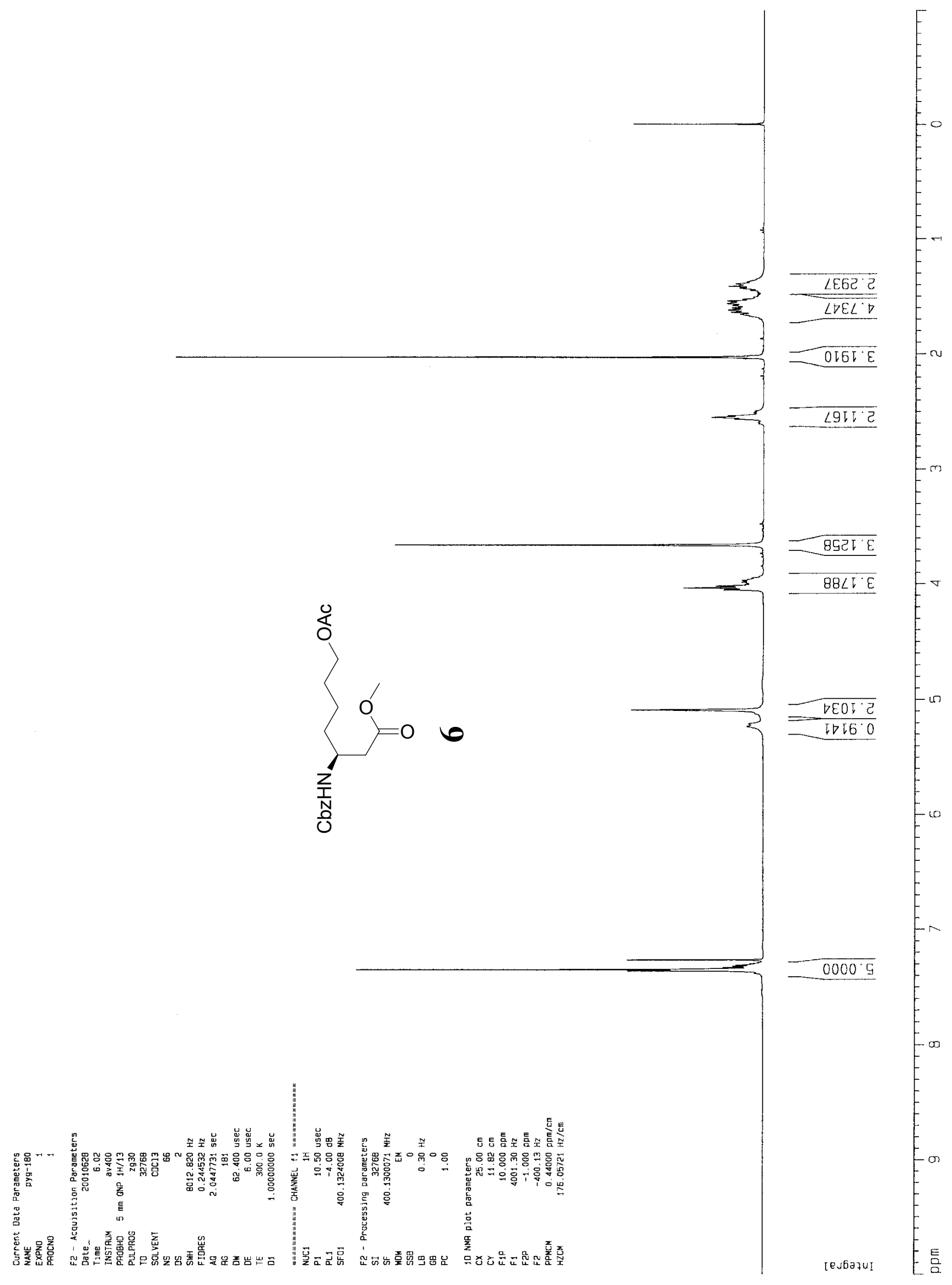


OE6 02

IIS.

记・82

ट86 ' $E \varepsilon$

geg. $8 E$

$\angle \nabla 0^{\circ} \angle \nabla$

$699^{\circ} \cdot 5$

$560^{\circ} \mathrm{b9}$

$929.99-$

$\nabla 89^{\circ} 9 L$

$E 00^{\circ} \mathrm{LL}$

$O C E^{\prime} \angle L$

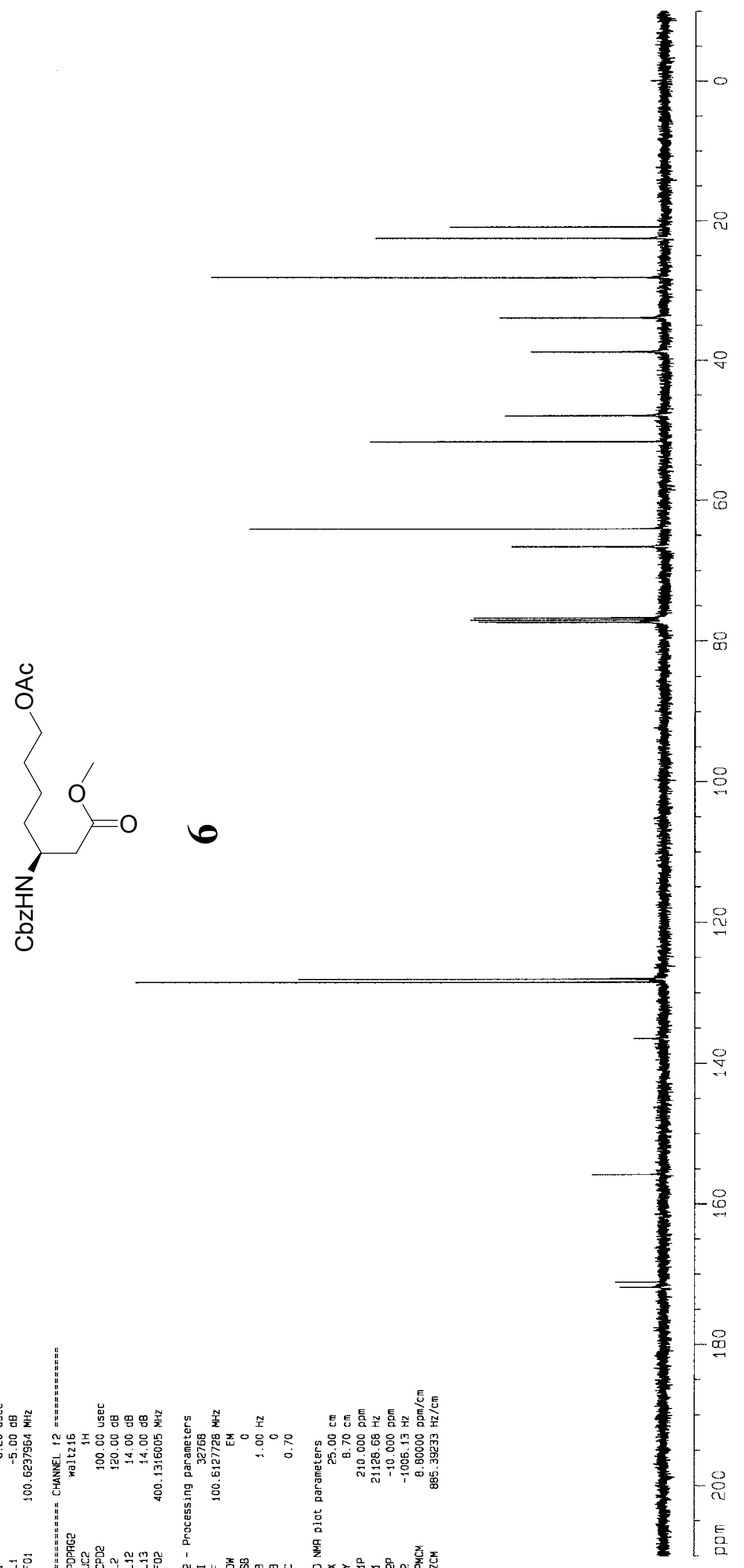

050.851

6 $\angle 0$ 8ट

$5 \angle D^{\circ} 8 \mathrm{CL}$

टह० $9 \varepsilon$

レLG Sᄃ—

E己T'

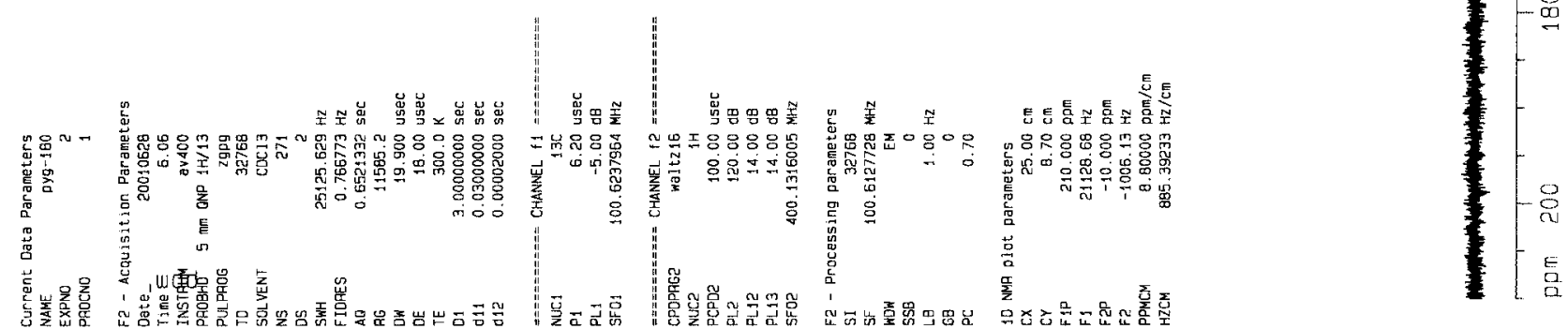




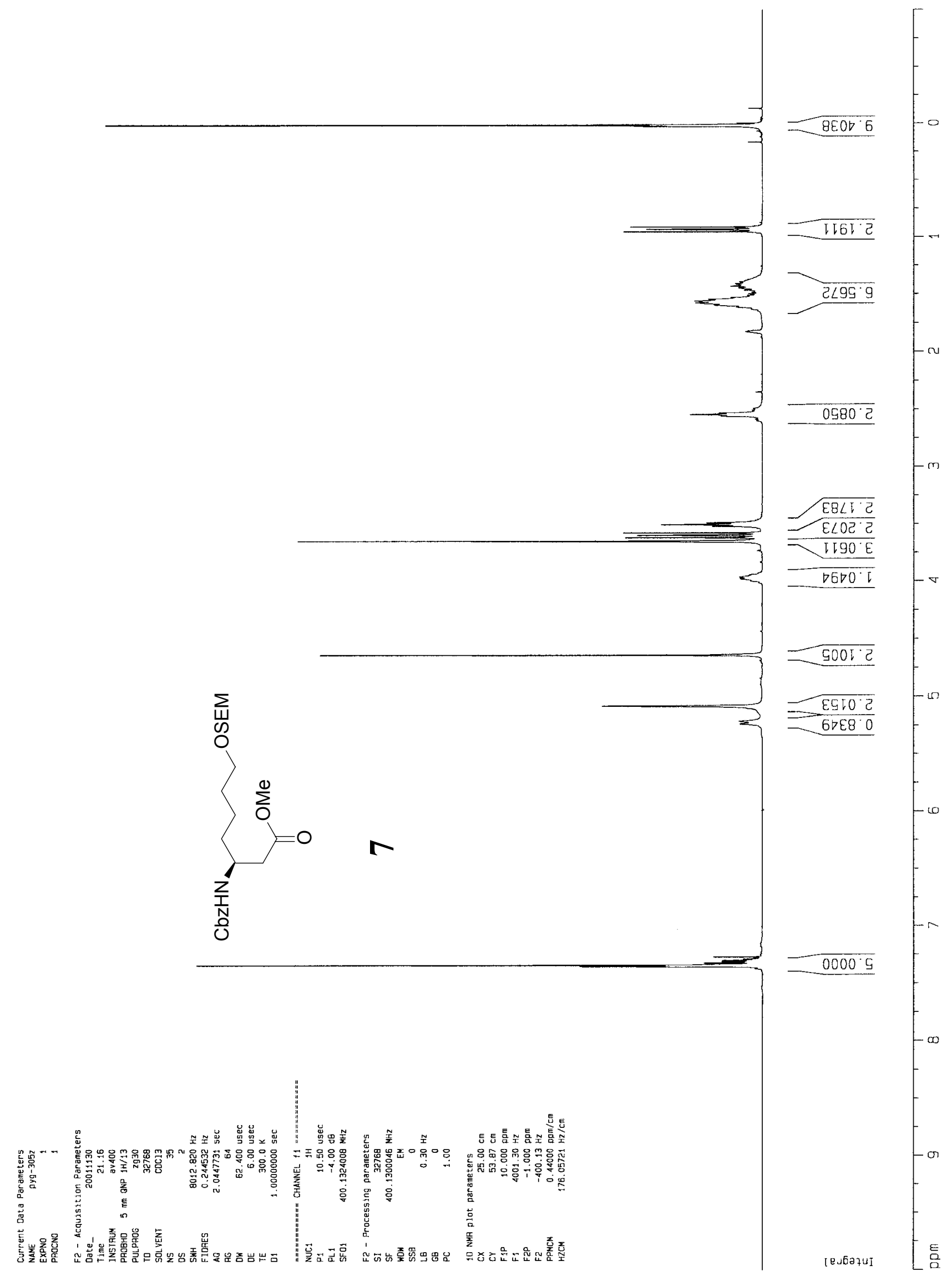


$\forall \angle V^{\circ} \downarrow-$

$980^{\circ} \mathrm{BI}$

EEB. 25

टEE 62

SᄃI'จE

$99 \angle \mathrm{BE}$

$290^{\circ} 87$

$089^{\circ}$ IS

$\nabla 16 \cdot \nabla 9 \longrightarrow$

$\nabla E G^{\prime} 99$

$6 \angle 9 \cdot 9 \angle$

$966^{\circ} 9 \angle$

$\checkmark$ IE' $L L$

$\sum_{\substack{W \\ 0}}$

$91<\nabla 6$

$2 \angle 6^{\circ} \angle 2$

$866^{\circ} \angle 2 T$

टट૪ 8टा

S9t $8 \mathrm{CI}$

$66 \nabla \cdot 9 E$.

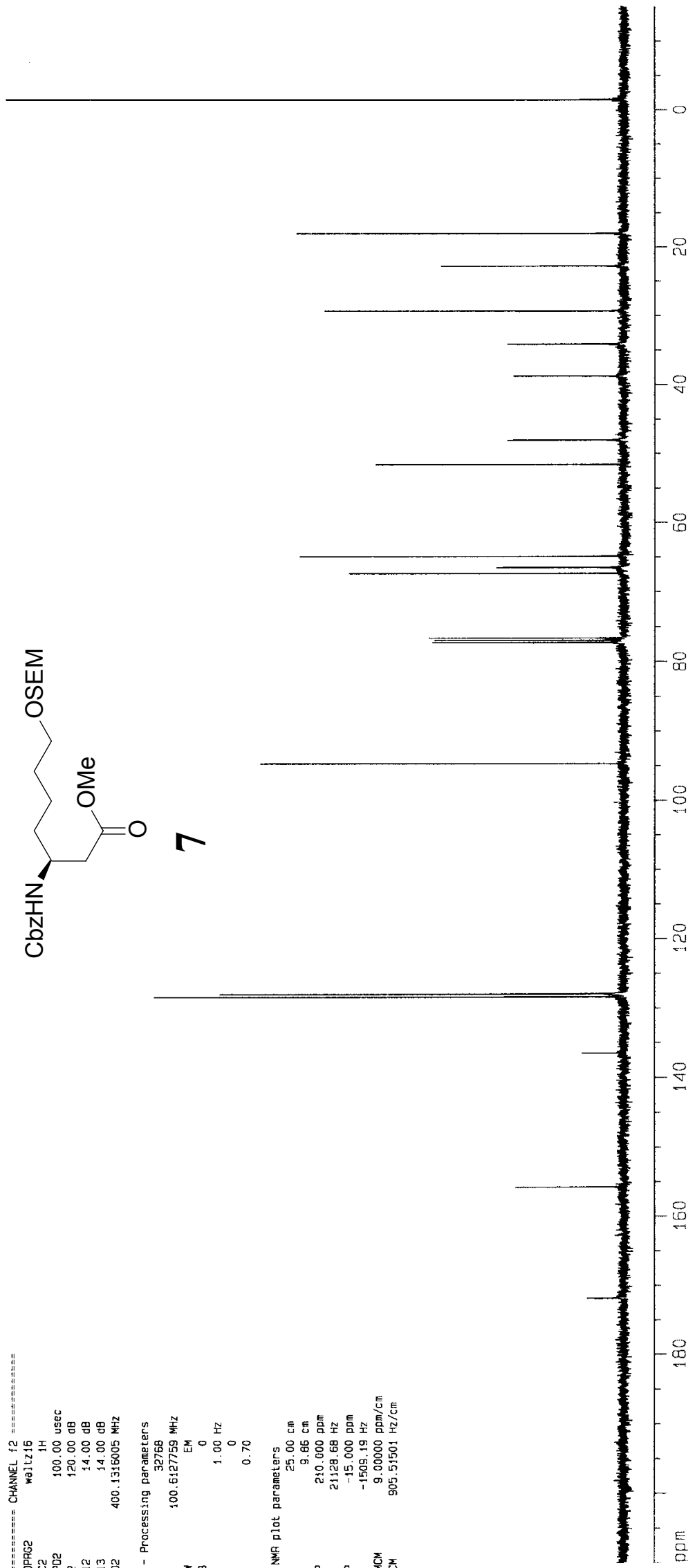

$90 L \mathrm{SS}$

$\nabla \angle 8 \cdot \square \angle V$

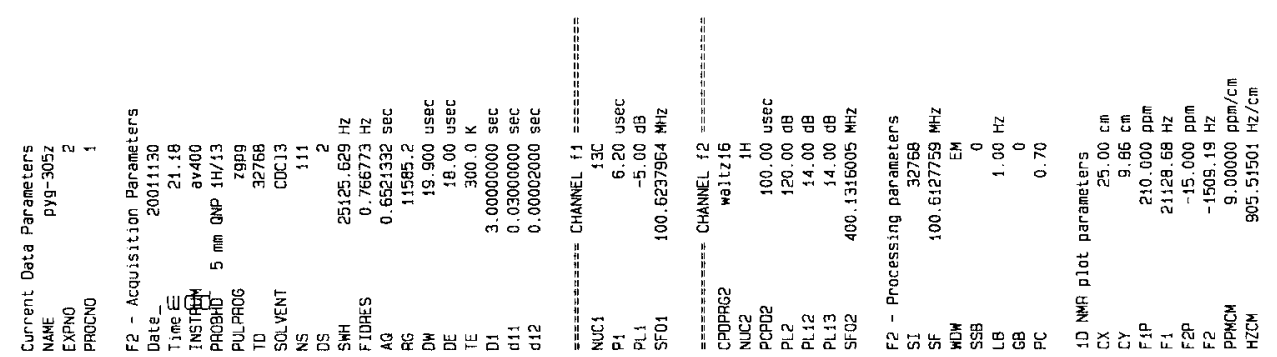




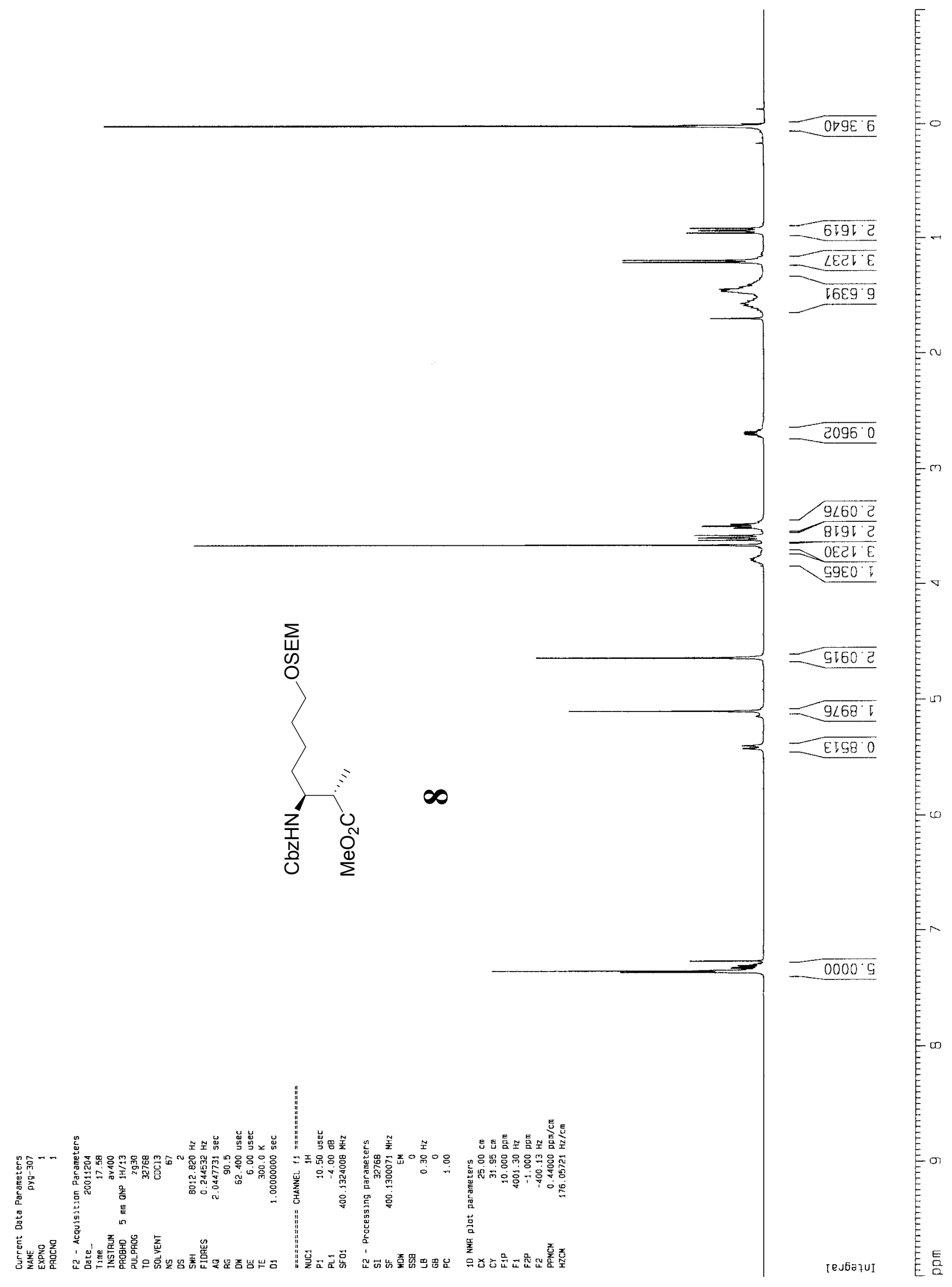


8Eל โ

S6L' $\supset$ -

$9 \angle 0^{\circ} 8 \mathrm{~T}$

0 อ

2己》 62

$928^{\circ} \varepsilon E$

8L9'2

こ๐9. IS

$056^{\circ} \nabla 9$

$899^{\circ} 99$

$967^{\circ} \angle 9$

$\triangleright 89^{\circ} 9 L$

$100 \angle L$

GIE $\angle L$

GSL・ $\nabla 6$

6E6 $\angle 己 L$

100 日टा

g97 $8 \mathrm{~d}$.

$\angle 99^{\circ} 9 E$,

E6 99\lceil

¿Eg. $g / \tau$

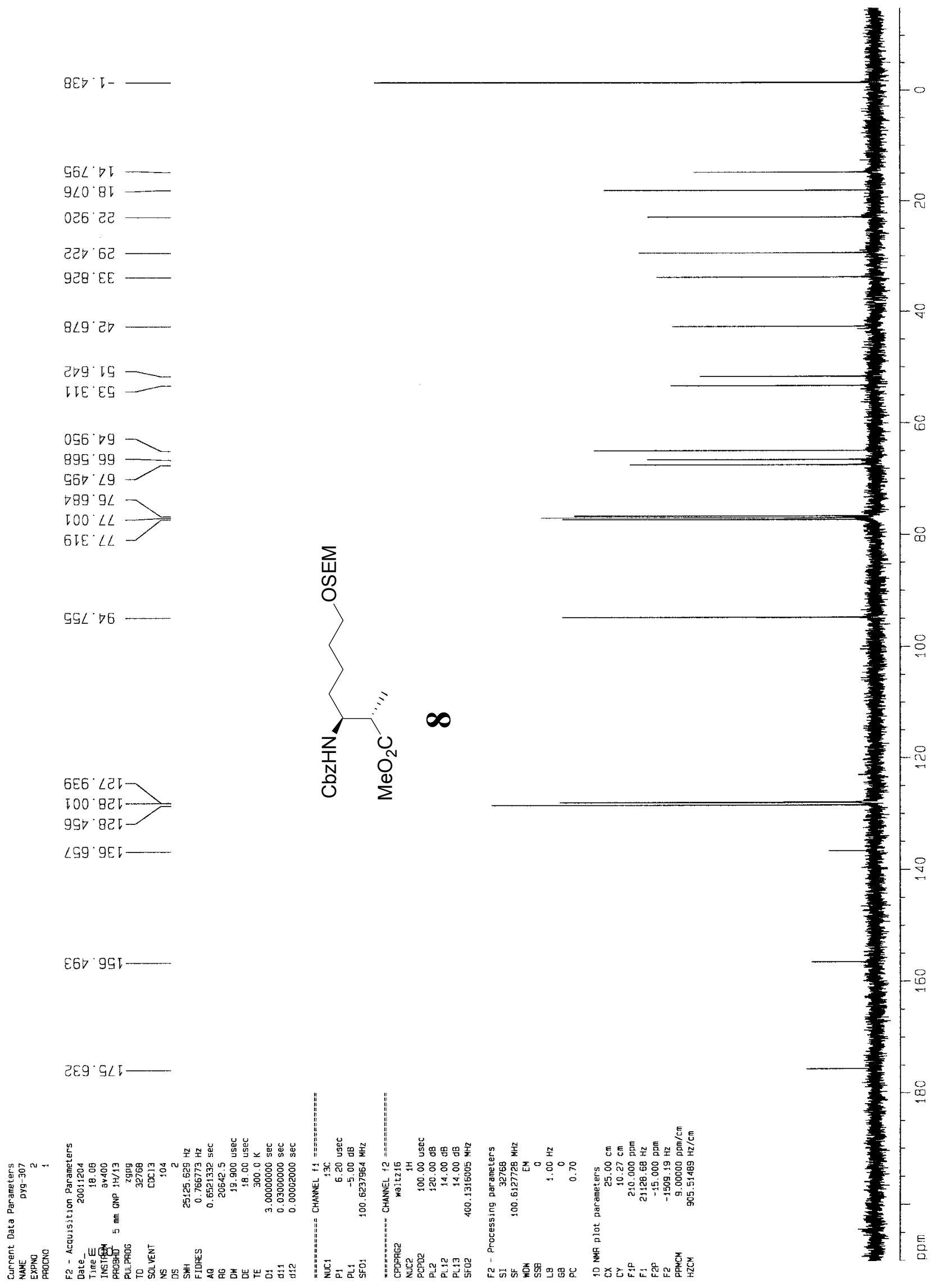




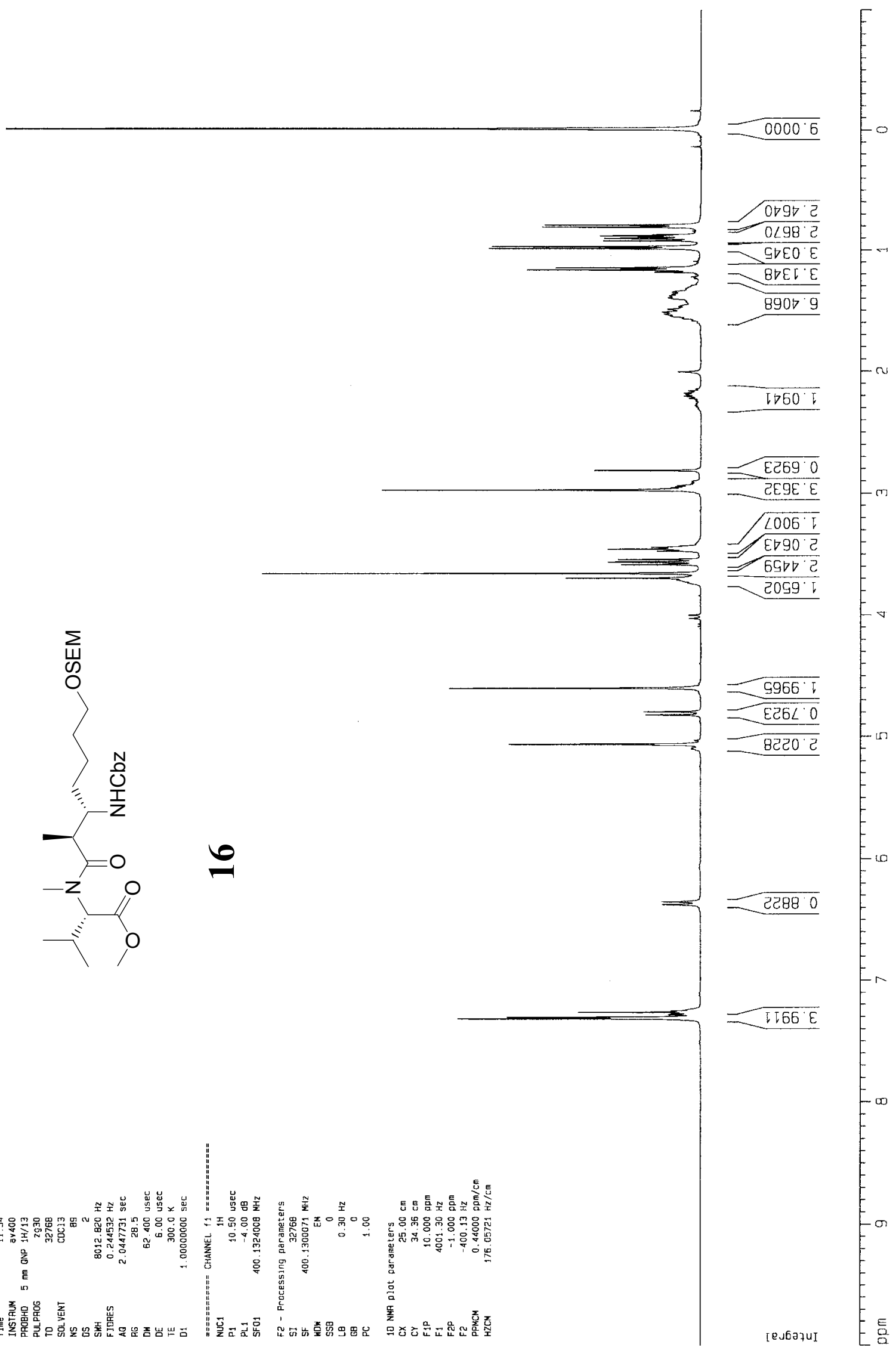


$629^{\circ} \mathrm{L}$

$988^{\circ}$

ट96. $\angle$

BES 81

$\angle E L{ }^{\circ} B I$

25०6I

$\angle I 8^{\circ} 61$

ट56. 22

LटIEट

टEट ' $\angle 2-$

$929 \cdot \angle 2$

टद9. 82

$90 \nabla^{\circ} 62$

$\angle E D \cdot 62$

टटL $L E$

$\angle T E^{\circ} \varepsilon \varepsilon-$

$\left\lceil\angle 0^{\circ} 8 E-\right.$

$\angle 69^{\circ} 8 E^{\circ}$

EIL'IG

000.29

$900^{\circ} \mathrm{VG}$

$\angle 6 己^{\circ} \nabla G$

$\angle 90^{\circ}$ '

$\triangle 08 \cdot \nabla 9$

E9g. 59$]$

or 599

EED $\angle 9$

$6 \angle 9 \cdot 9 \angle$

$\angle 66^{\prime} 9 \angle$

$\angle 5 I \angle L$

GIE $\angle L$

$809^{\prime} \vee 6$

$995 \angle 2 I$

$\nabla 99^{\prime} \angle 21$

Gम2 825

G28 $9 E$ I
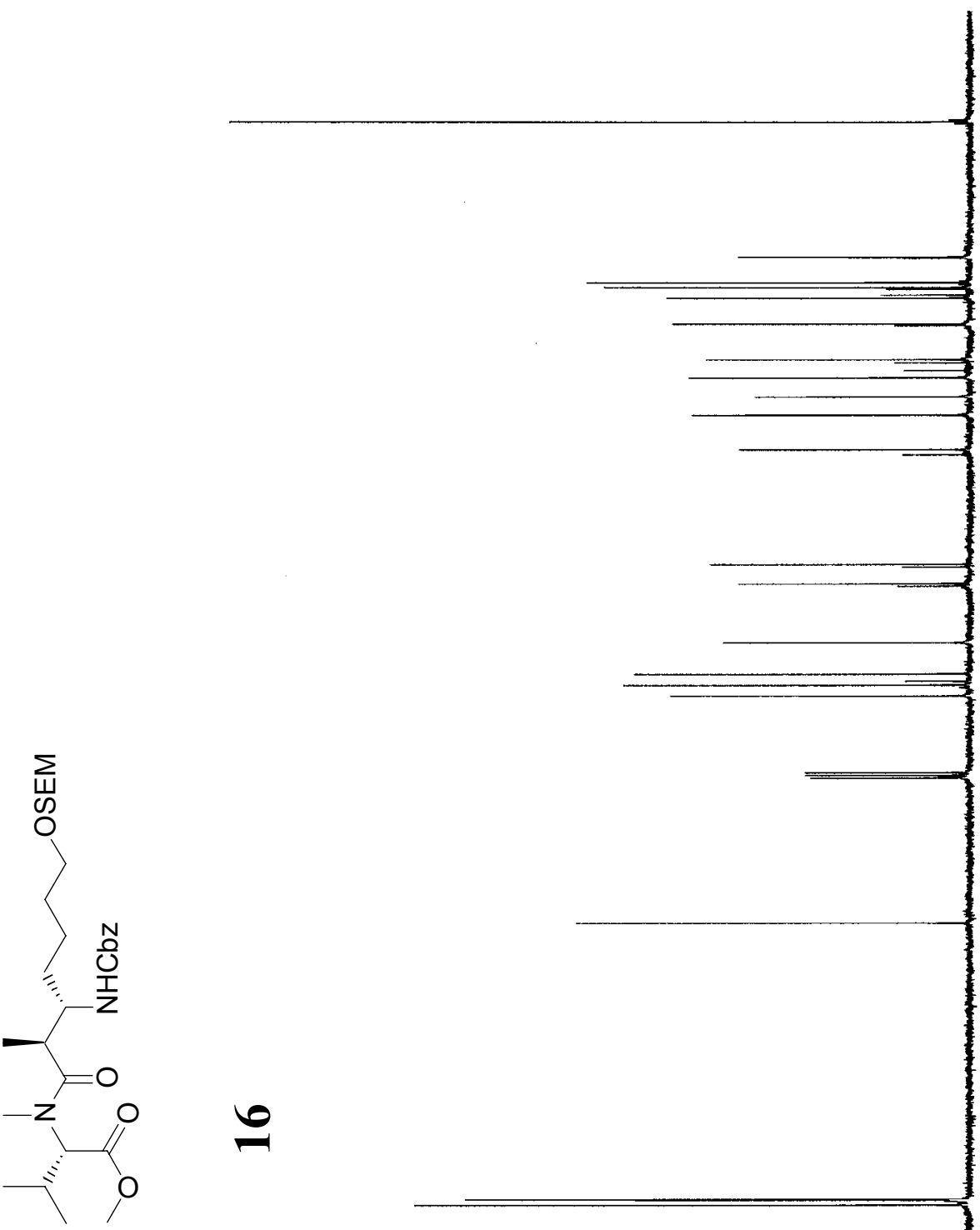

$-8$

웅

이

$\stackrel{8}{-1}$

ट2टL' 995

$69 L 991 \longrightarrow$

$\angle E T O \angle L D$

$\nabla 9 \tau \cdot L L=$

$69 \circ 9<1$

280 9L1

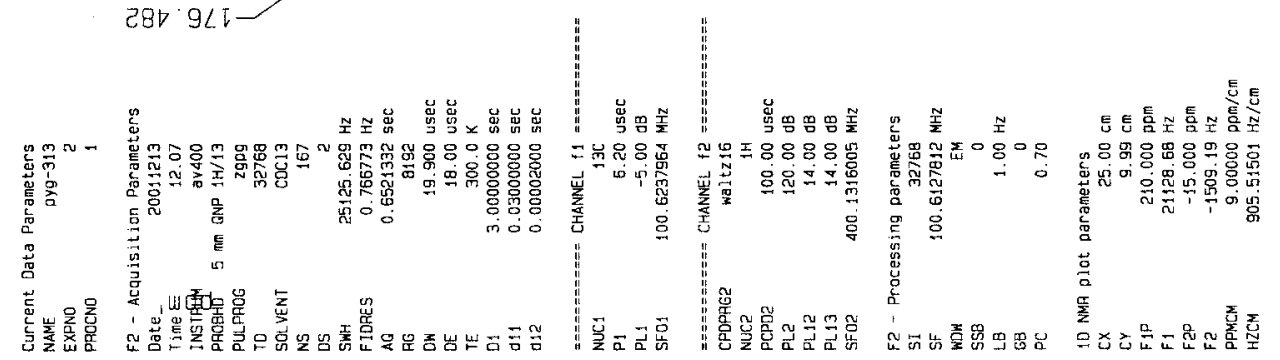




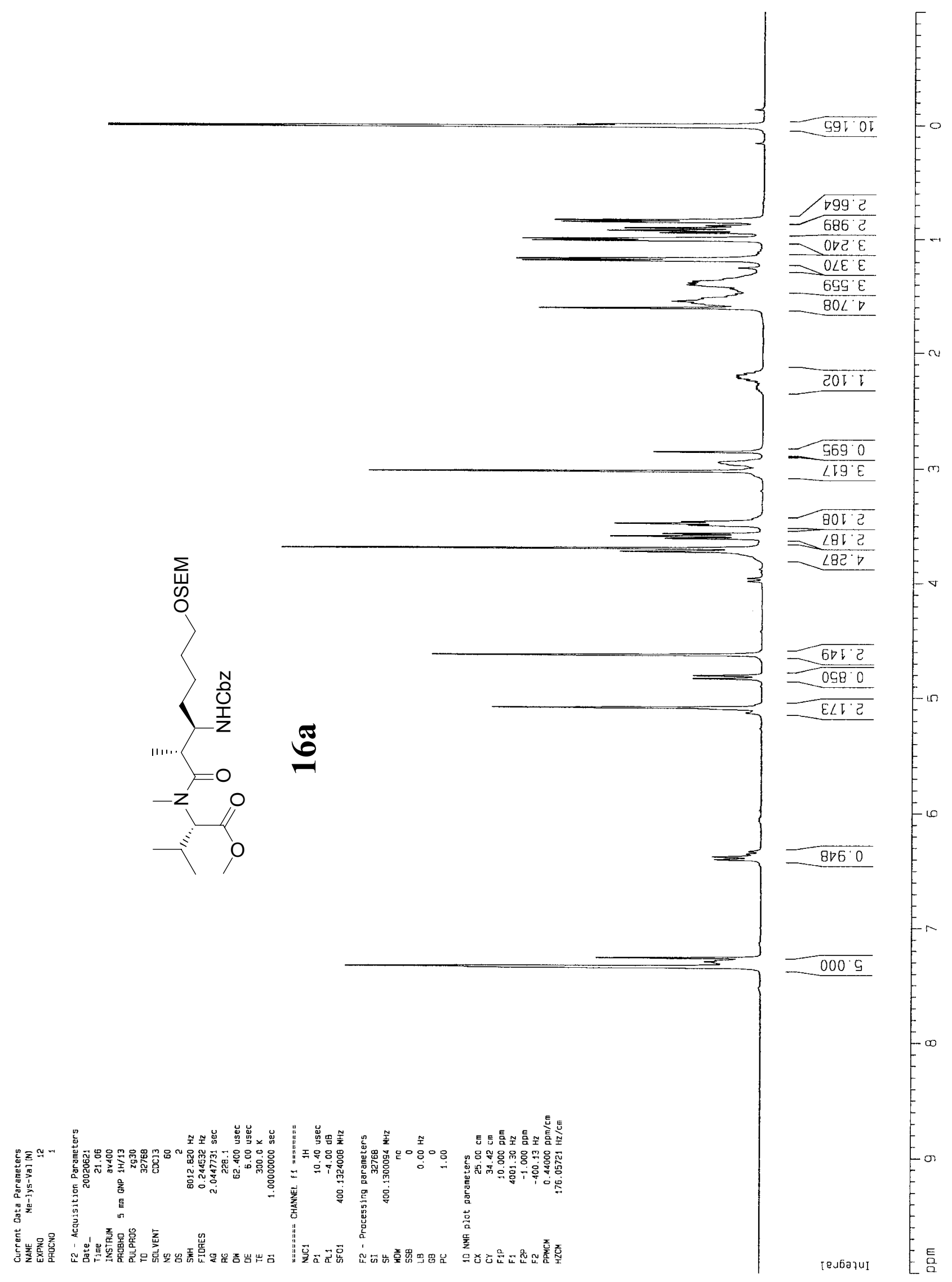




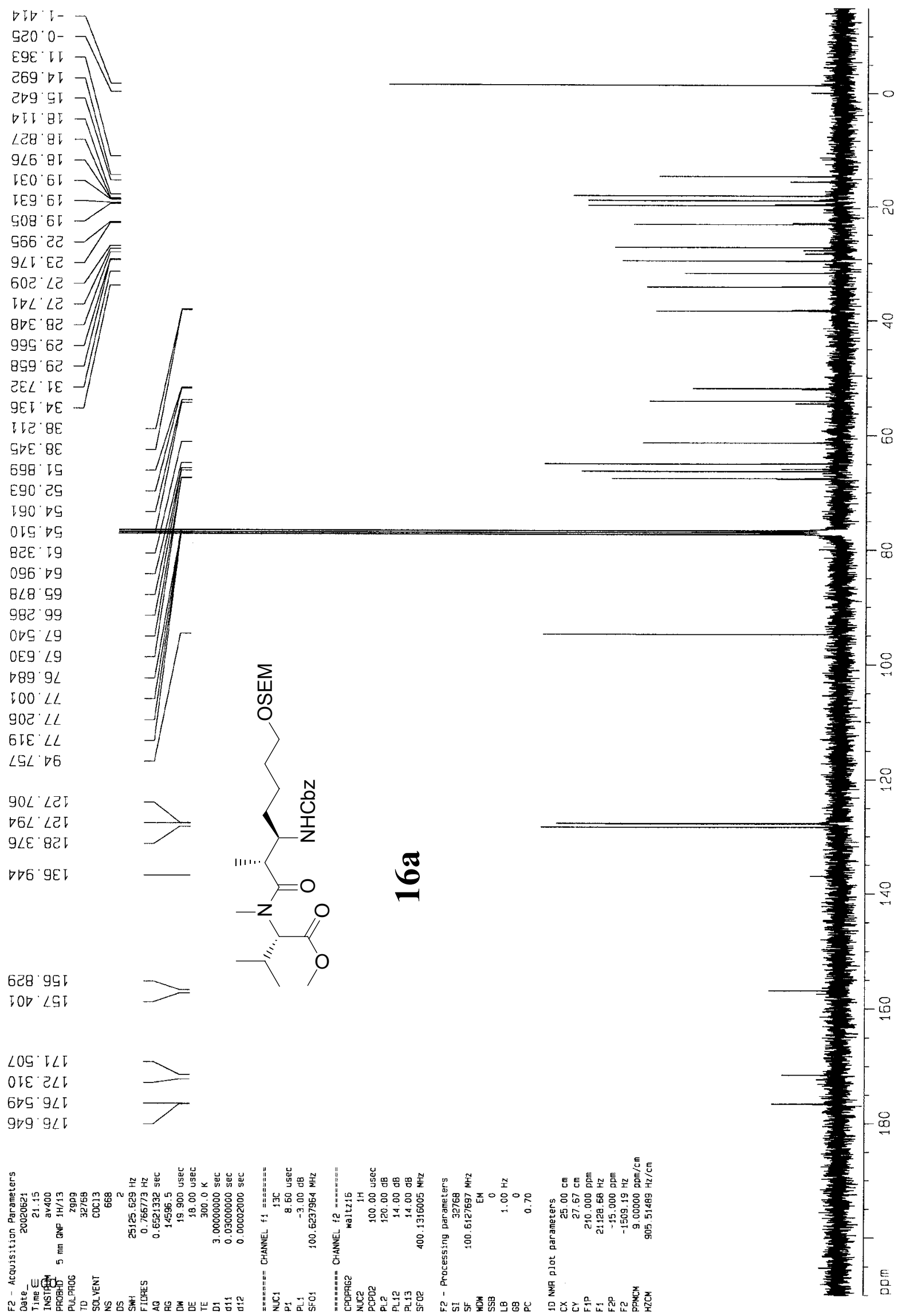




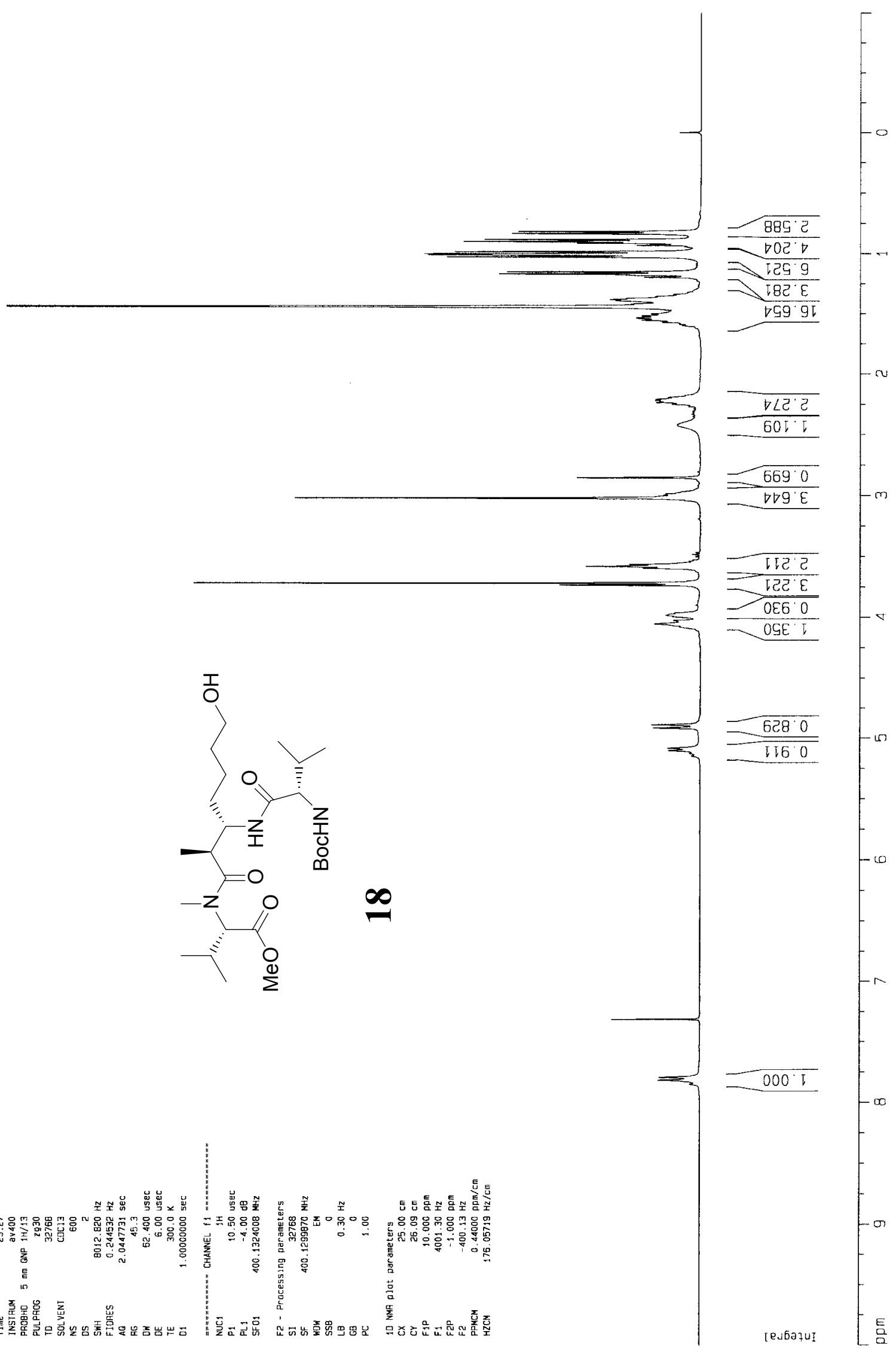



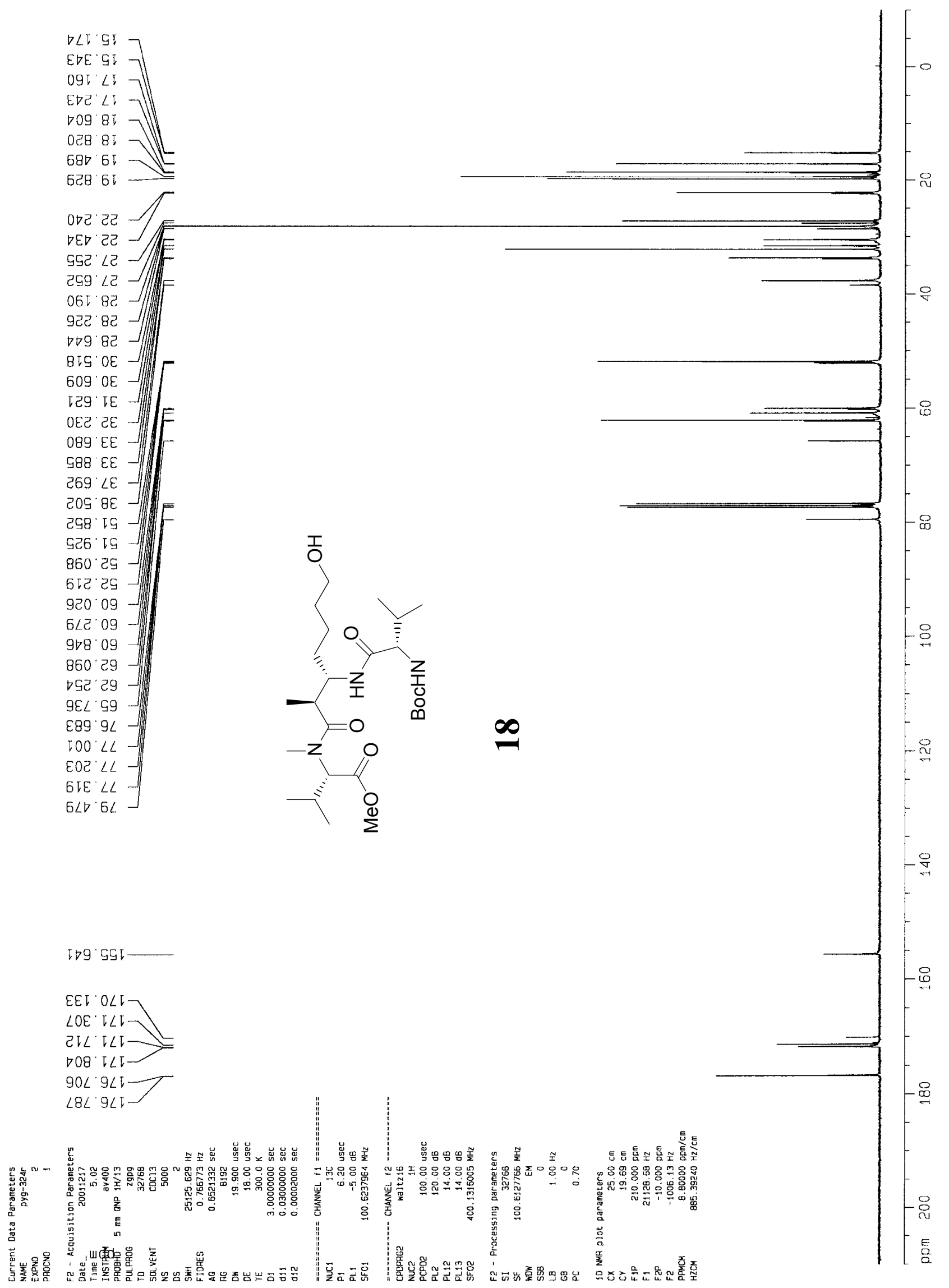

I 995

EEV $O \angle L$

$\angle O E^{\circ} \angle L T$

$2 L L \angle L$

$\checkmark 08^{\circ}$ L L L

$90 \angle 9 L$

$\angle 8 \angle ' 9 \angle \mathrm{V}$ 


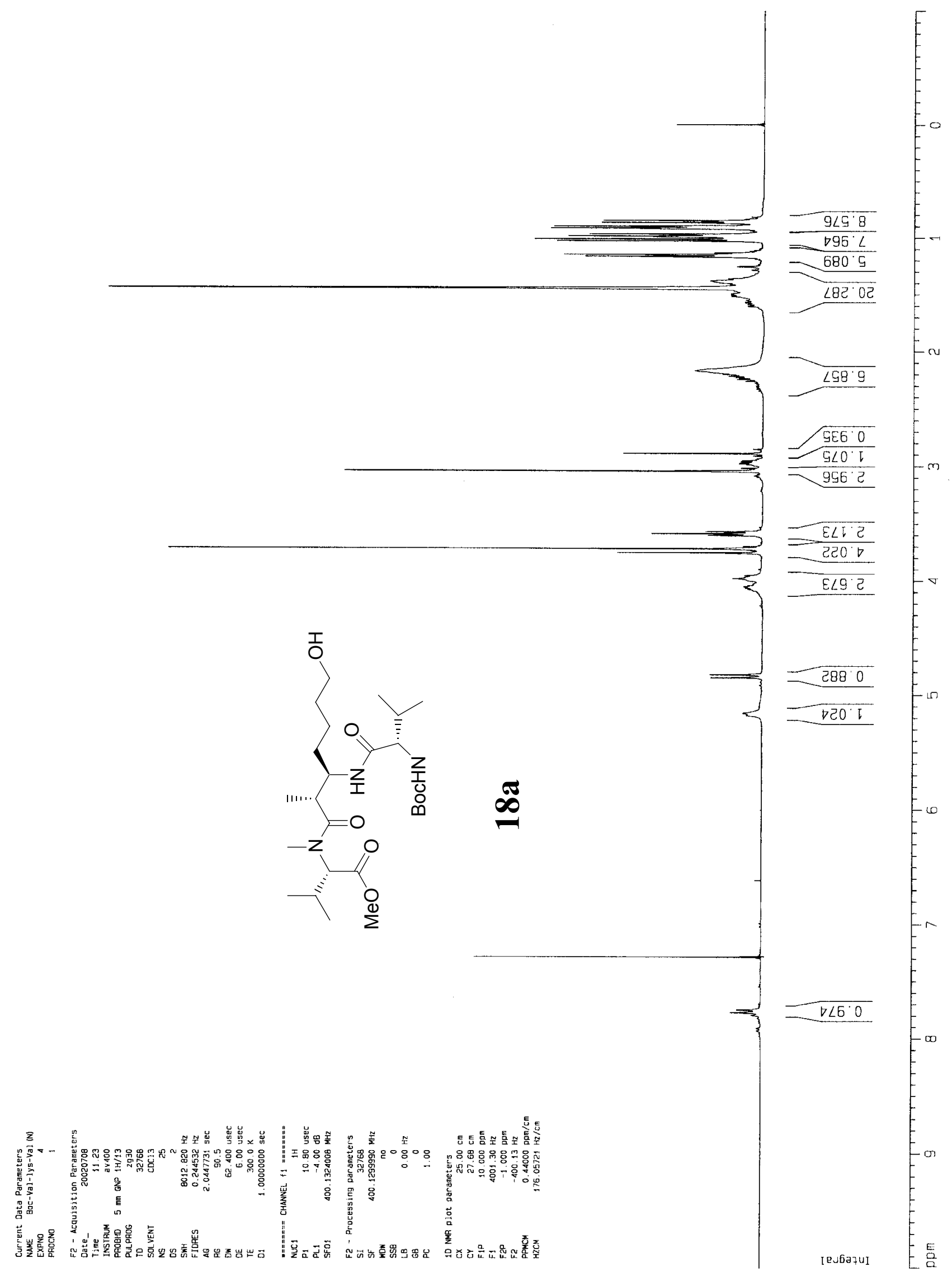




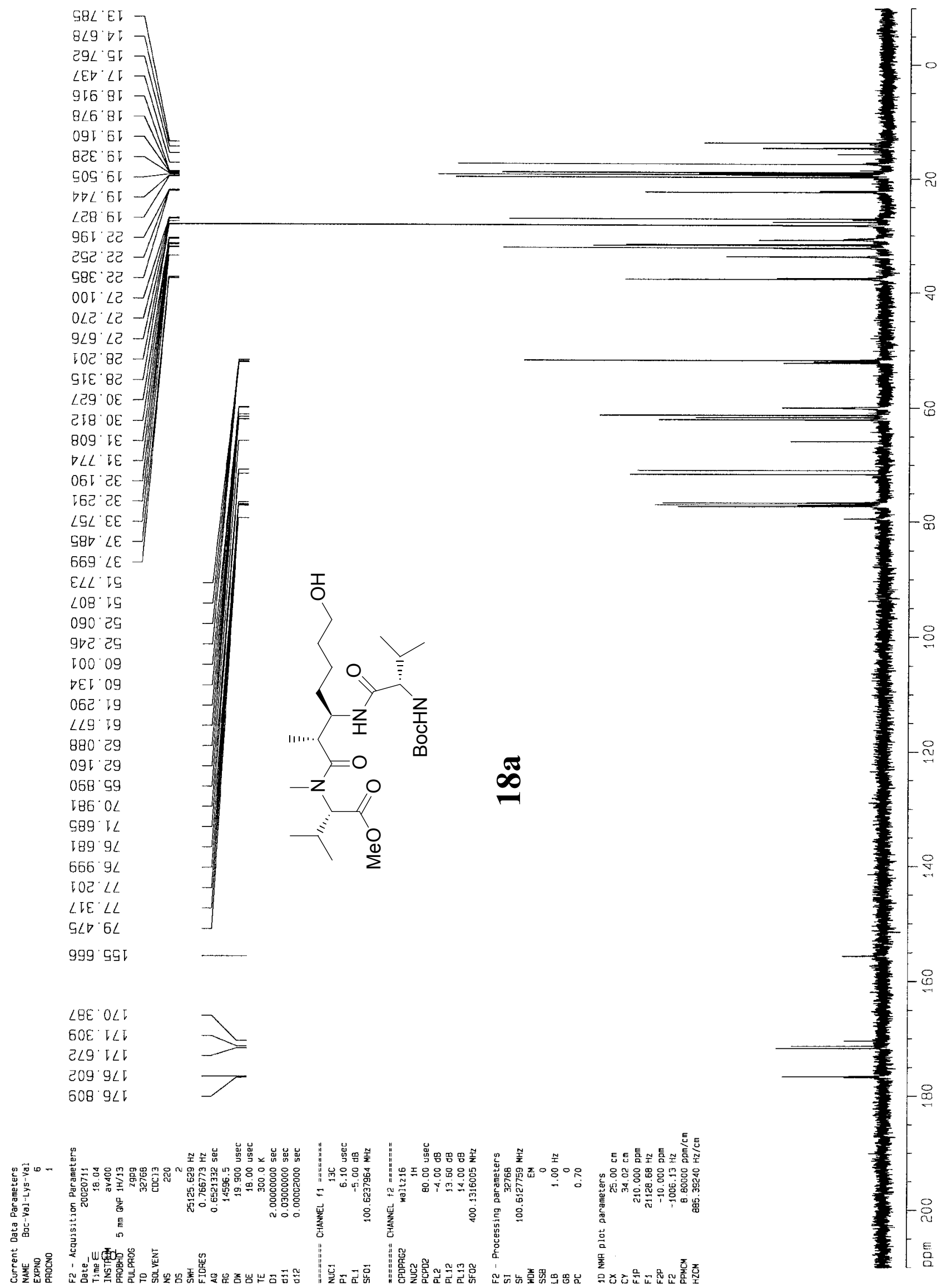




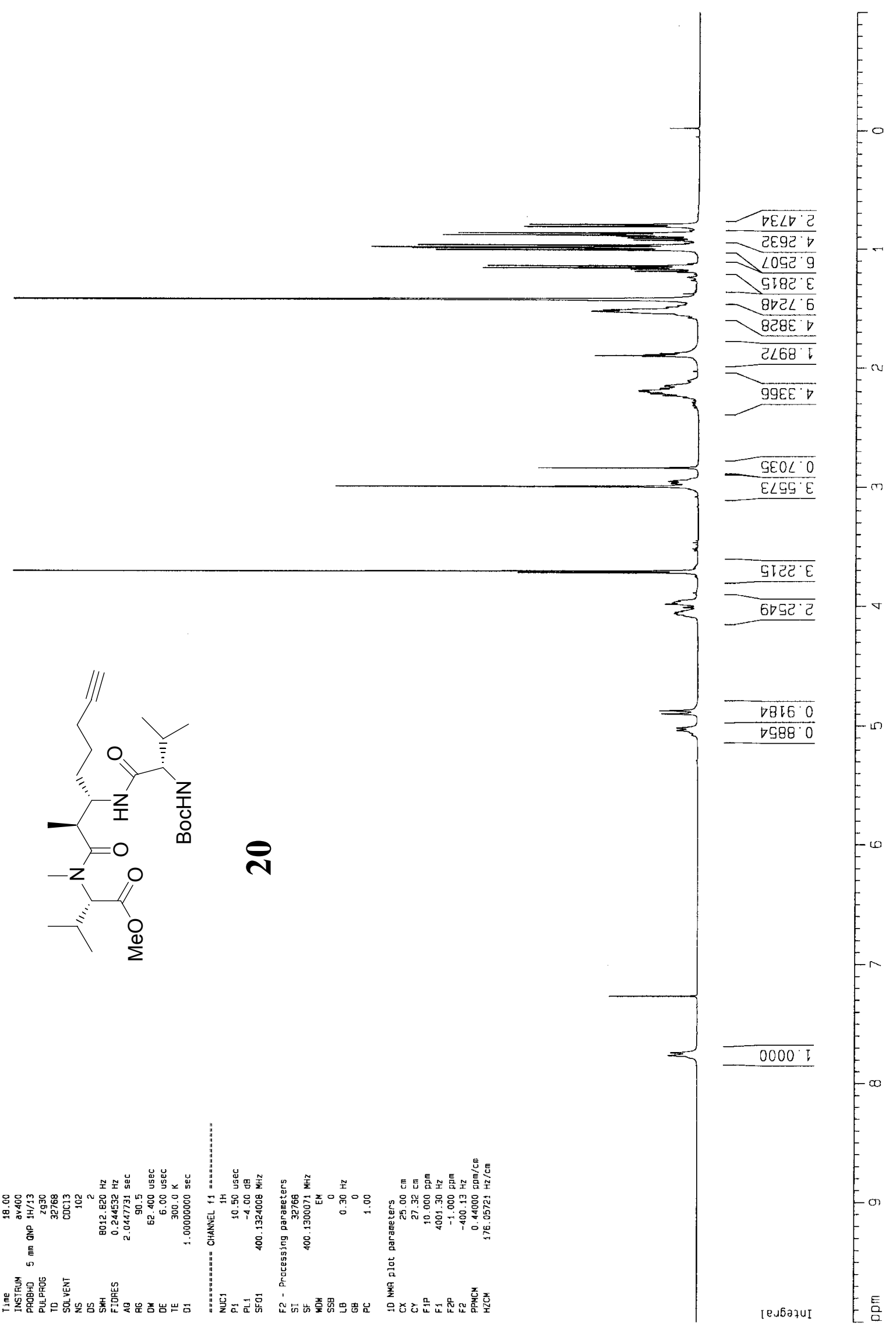

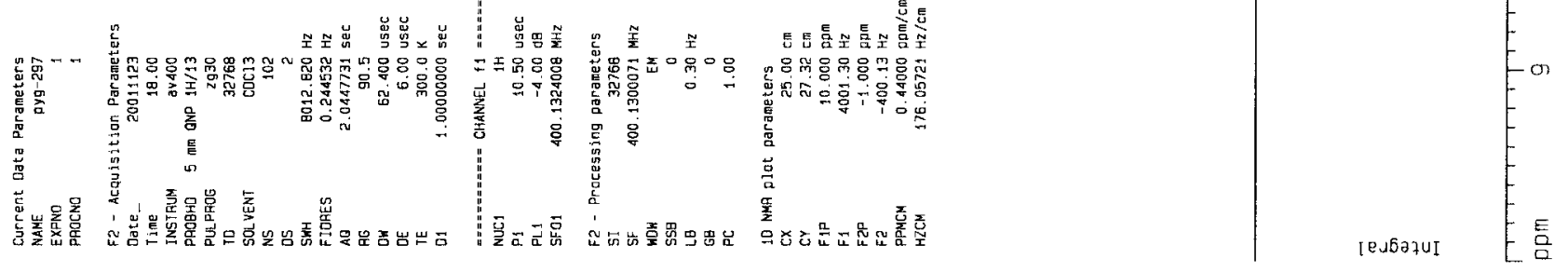



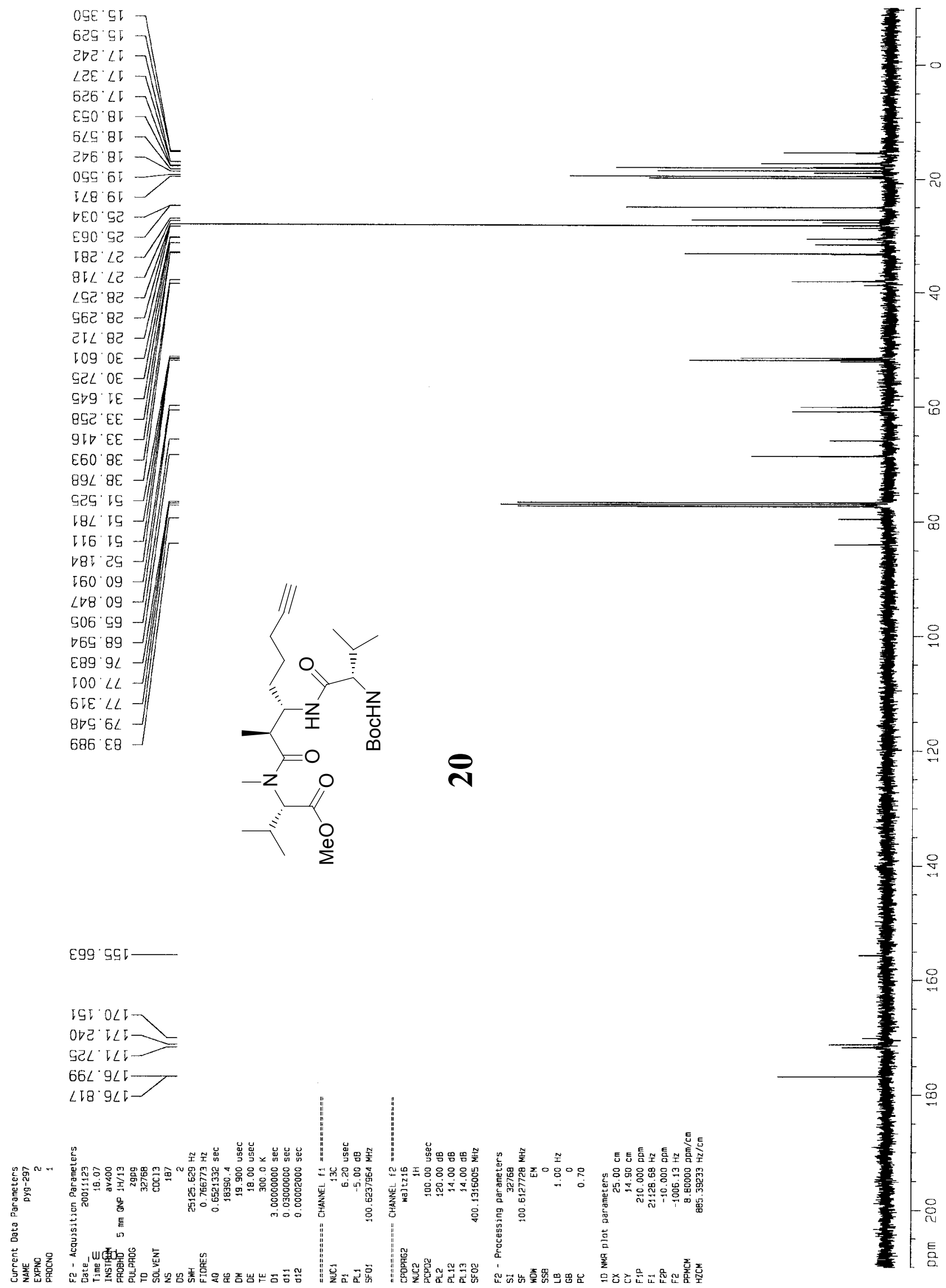

E99.99โ-

ISE $0 \angle 1$

ODE $1 \angle \mathrm{C}$

Gट $\angle L L L$

$66 \angle \cdot 9 \angle 5$

$\angle$ I8 $9 \angle[-$ 


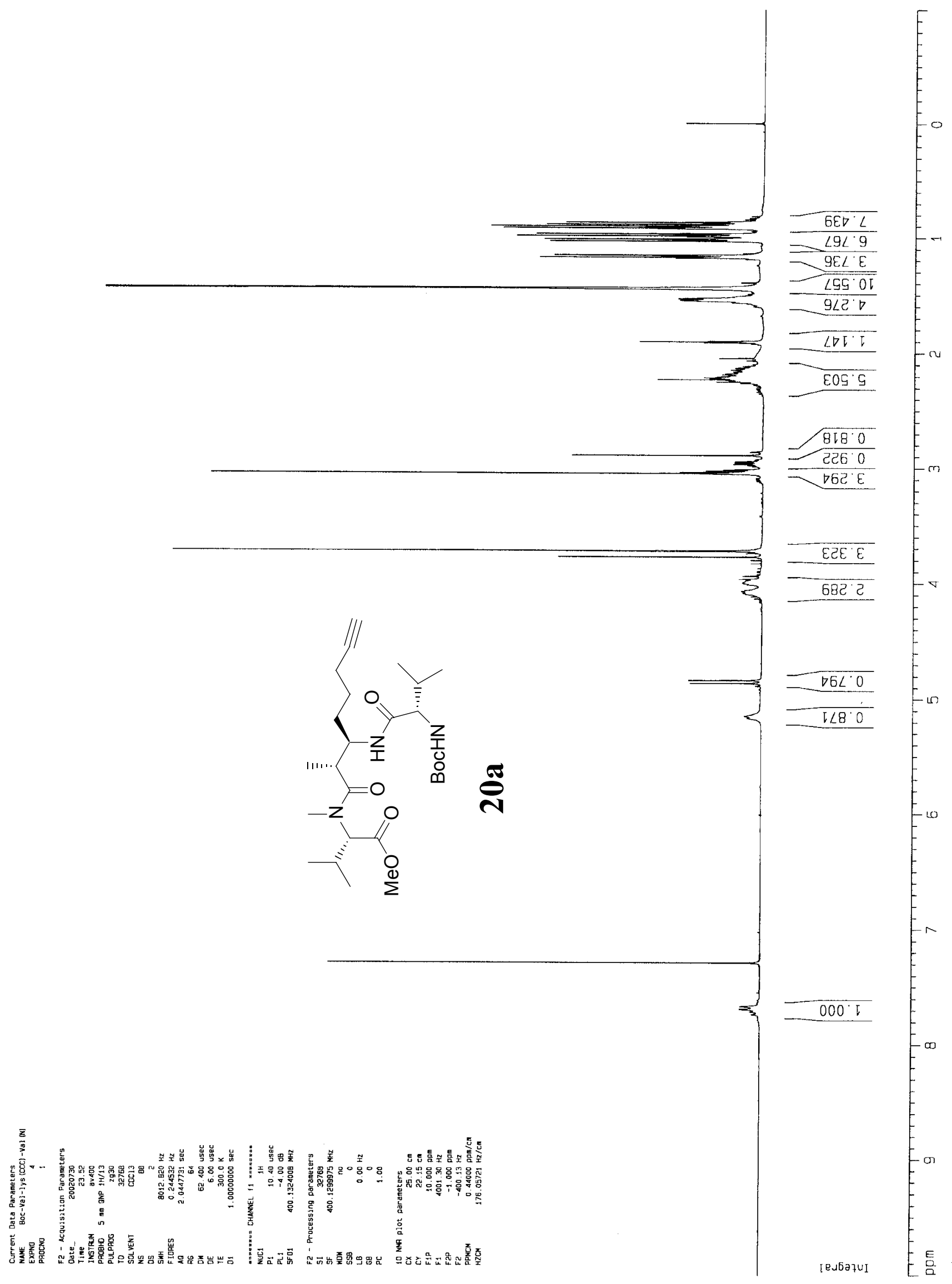




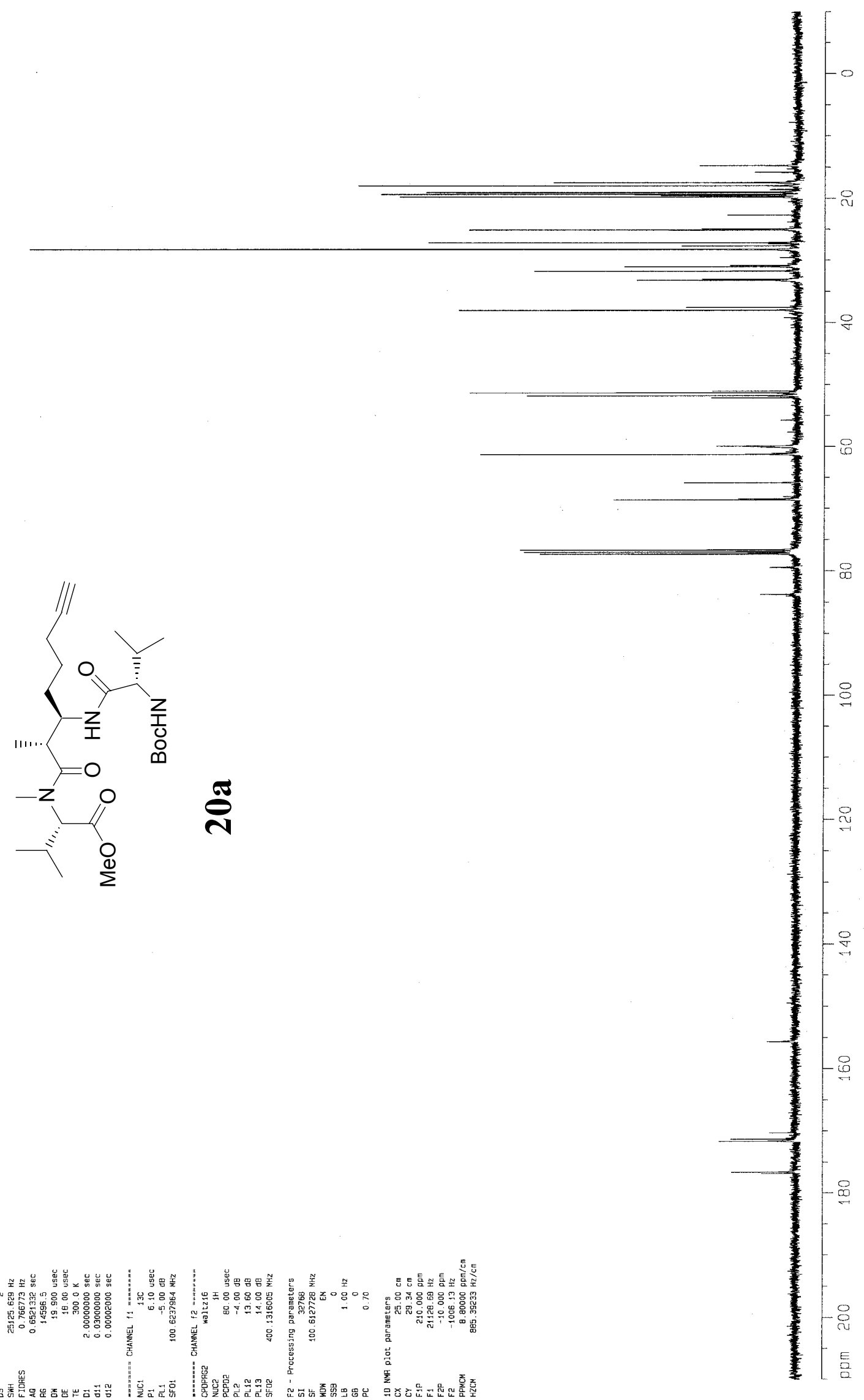

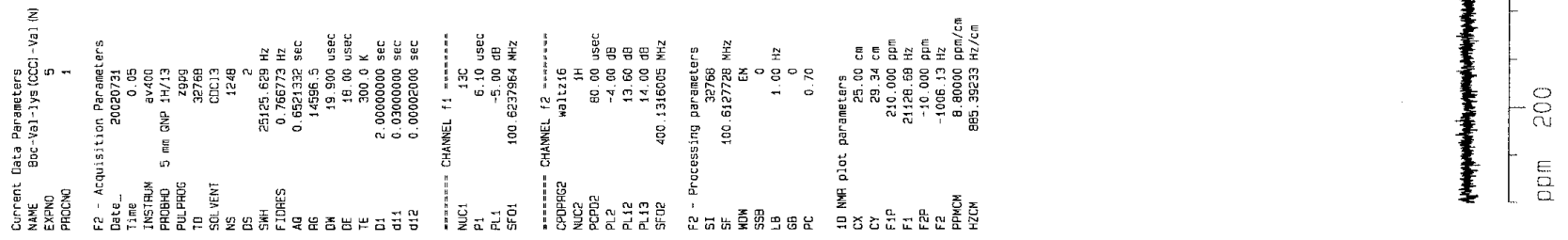




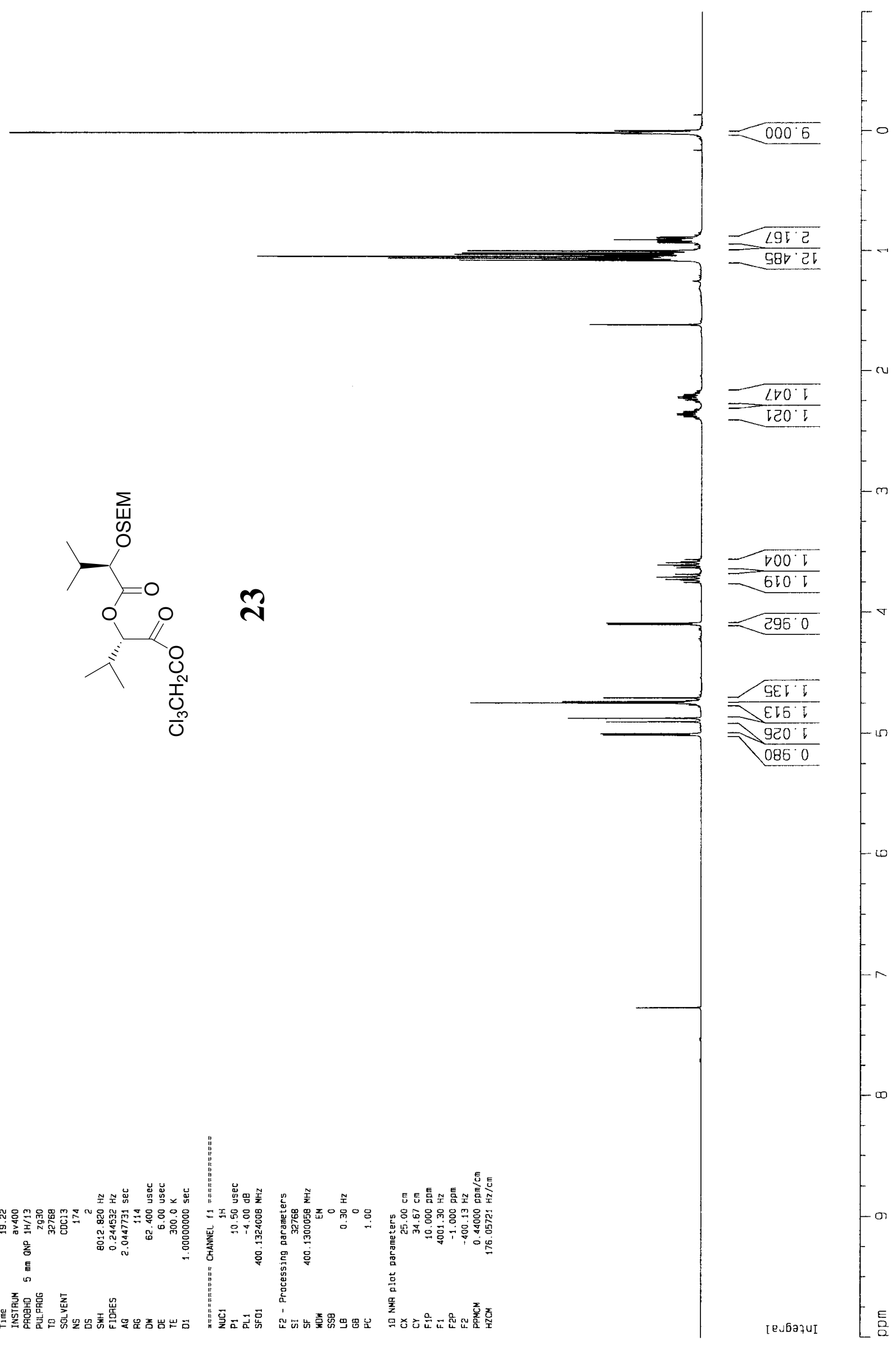




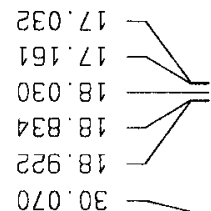

$O \angle 0^{\circ} O E_{-}$

690. IE

$09959 \longrightarrow$

6IZ $\nabla L$

$\left\lceil\angle \nabla^{\circ} 9 L\right.$

$969^{\circ} 9 L$

$189.9 L$

$666^{\prime} g L$

9IE' $\angle L$

$96 E^{\circ} \sigma L$

ट马टं $\nabla 6$.

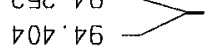<smiles>C=COC(=O)C(OC(=O)C(OC)C(C)C)C(C)(C)C</smiles>

$006^{\circ} \angle 9 F$

$\nabla 00^{\circ} \mathrm{C} \angle \mathrm{t} \ldots$

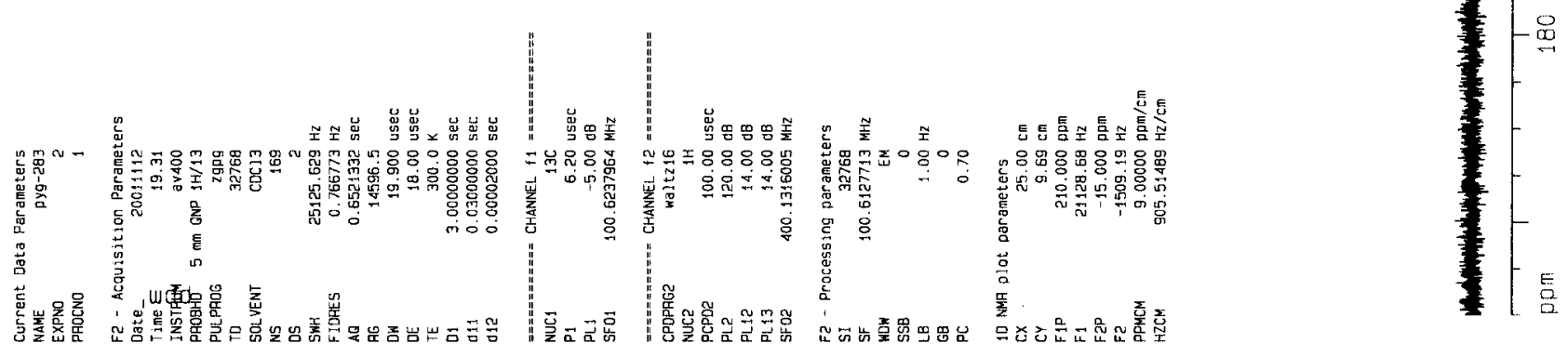




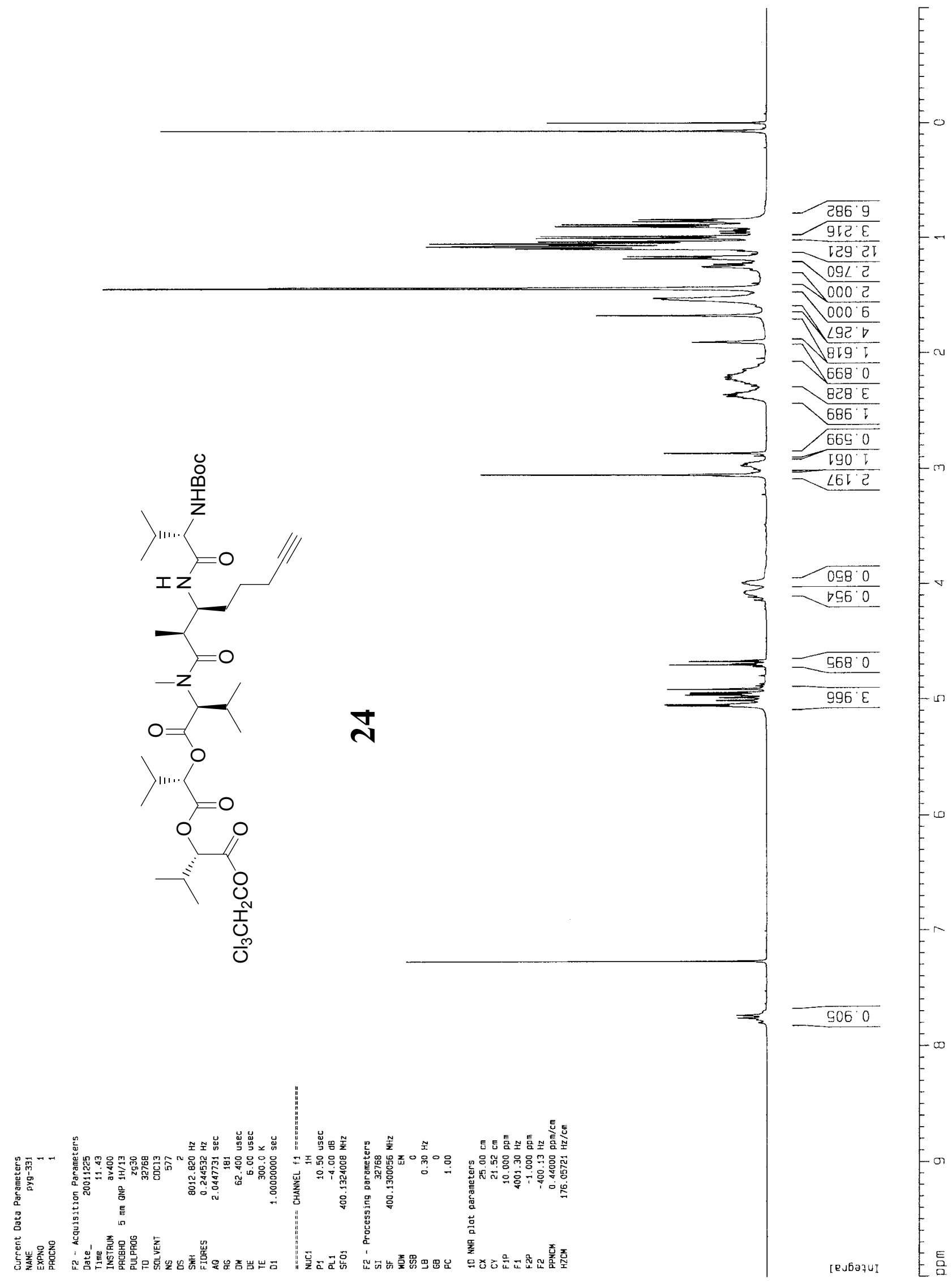




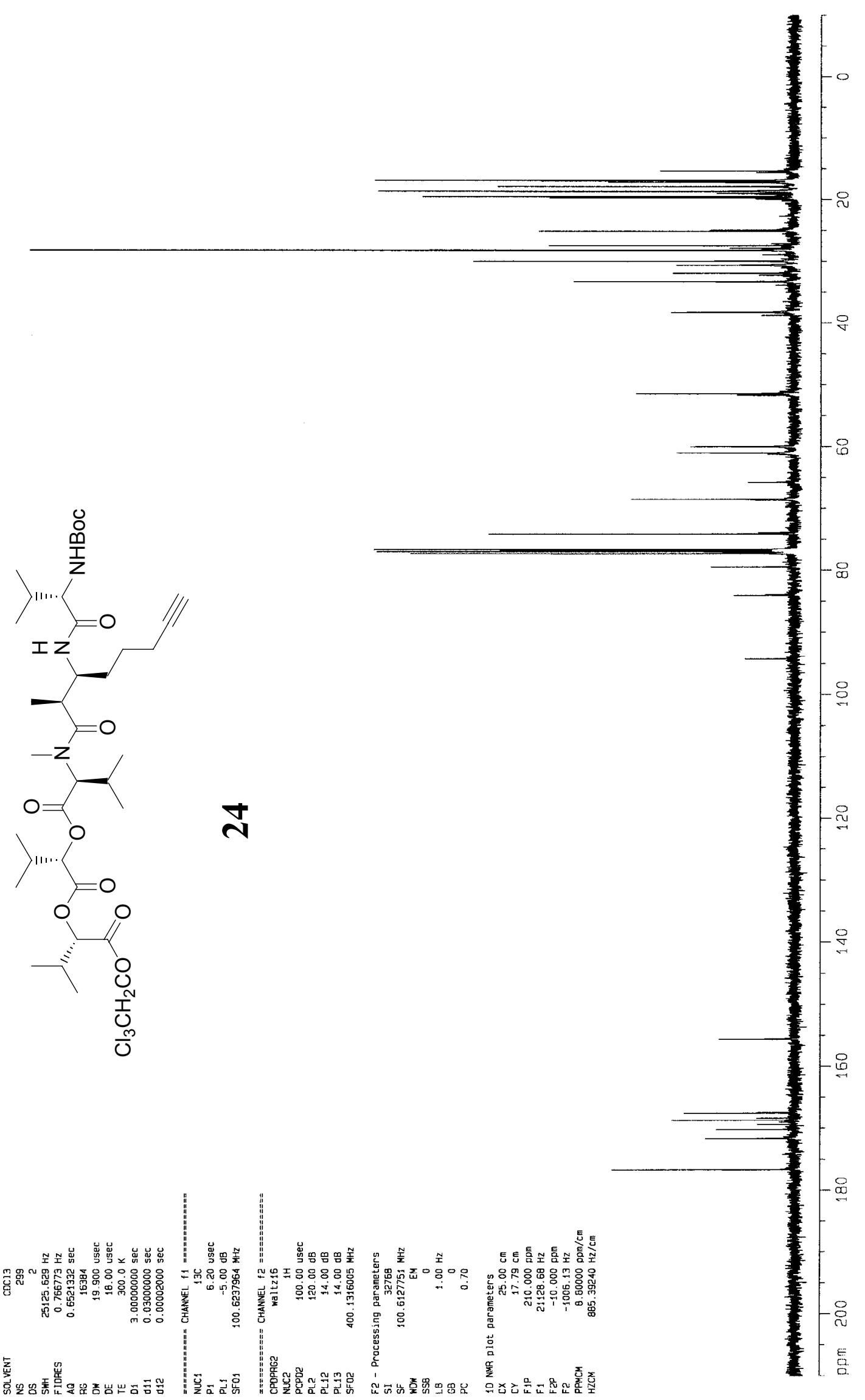




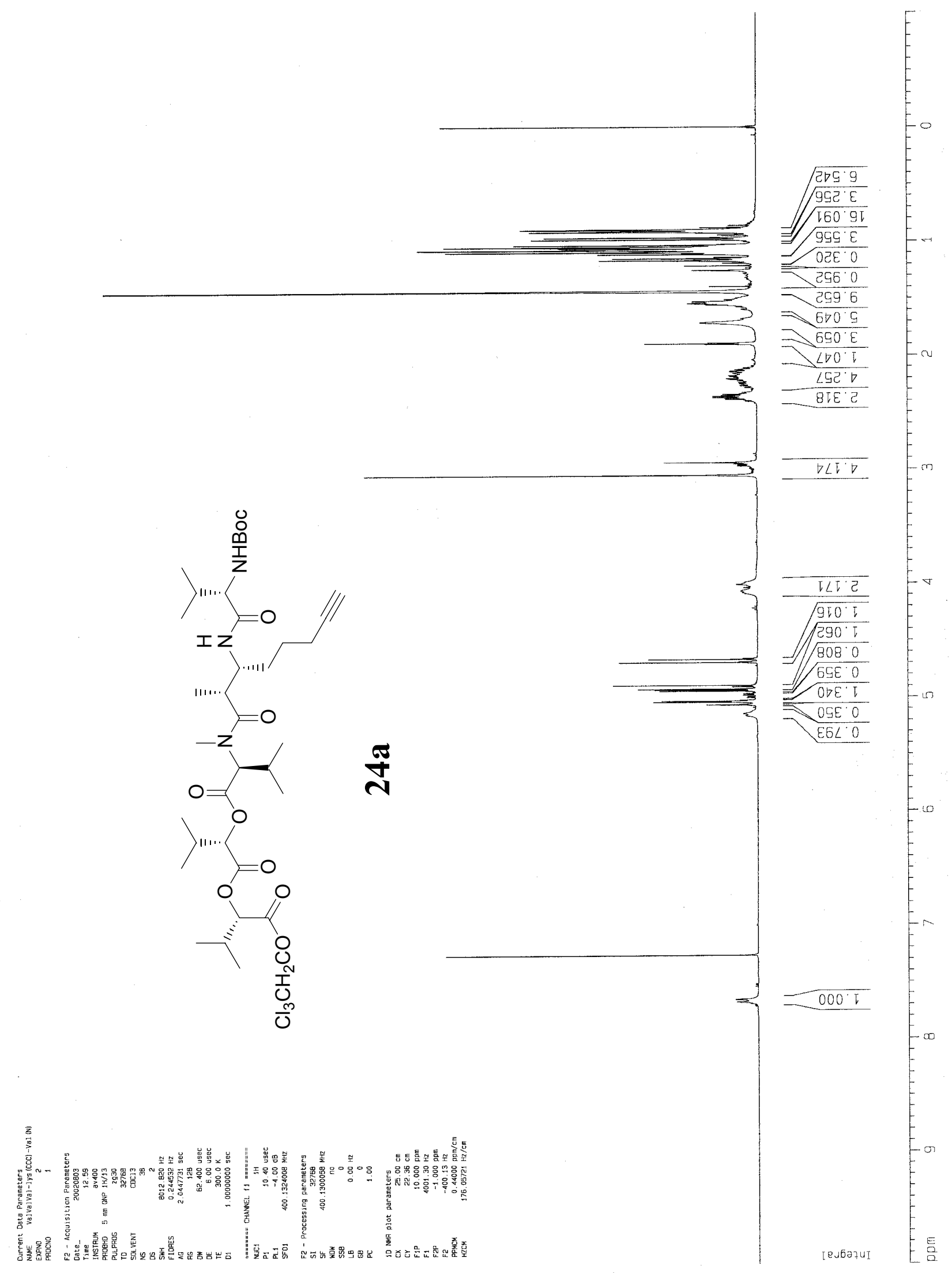




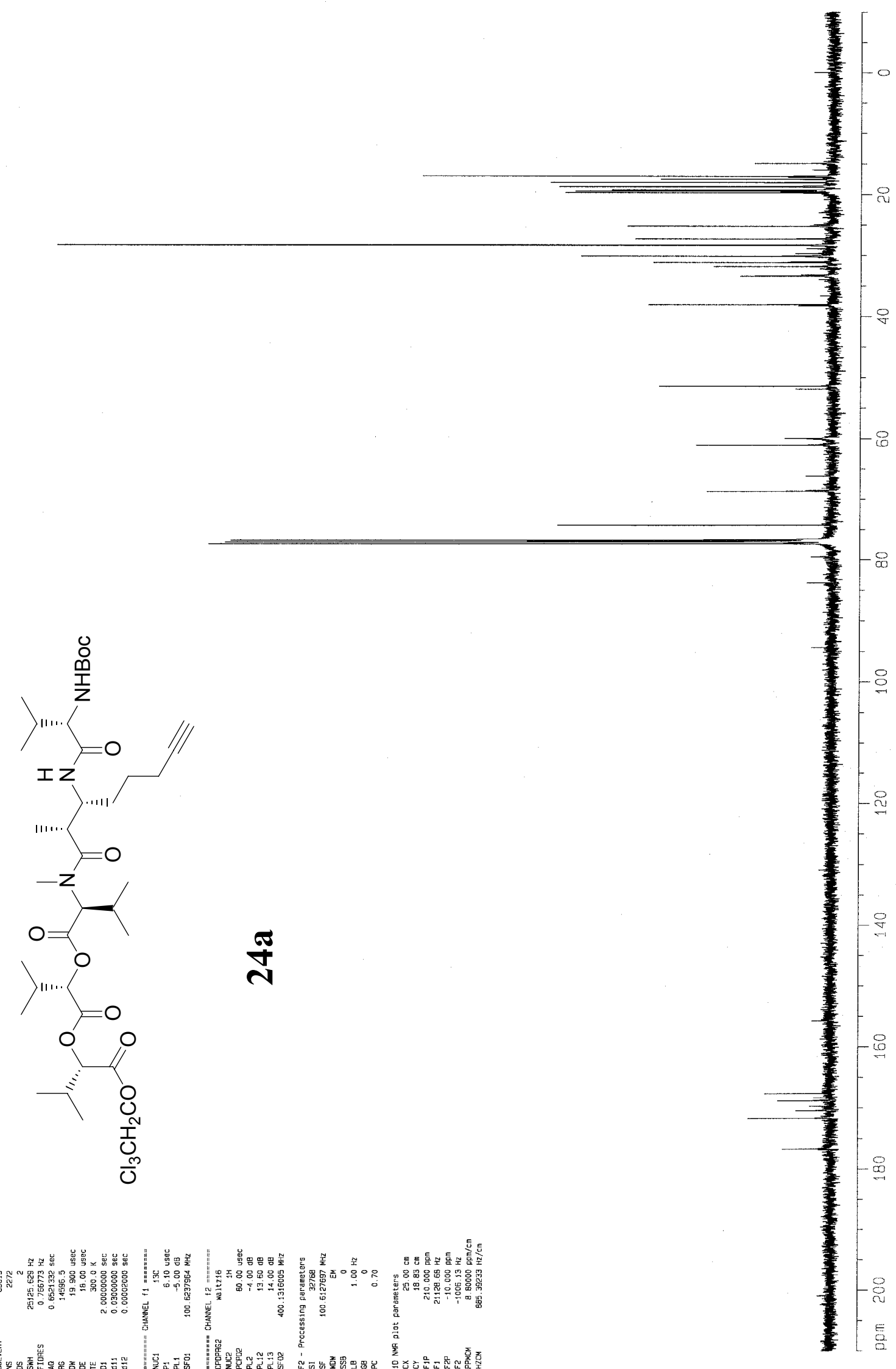




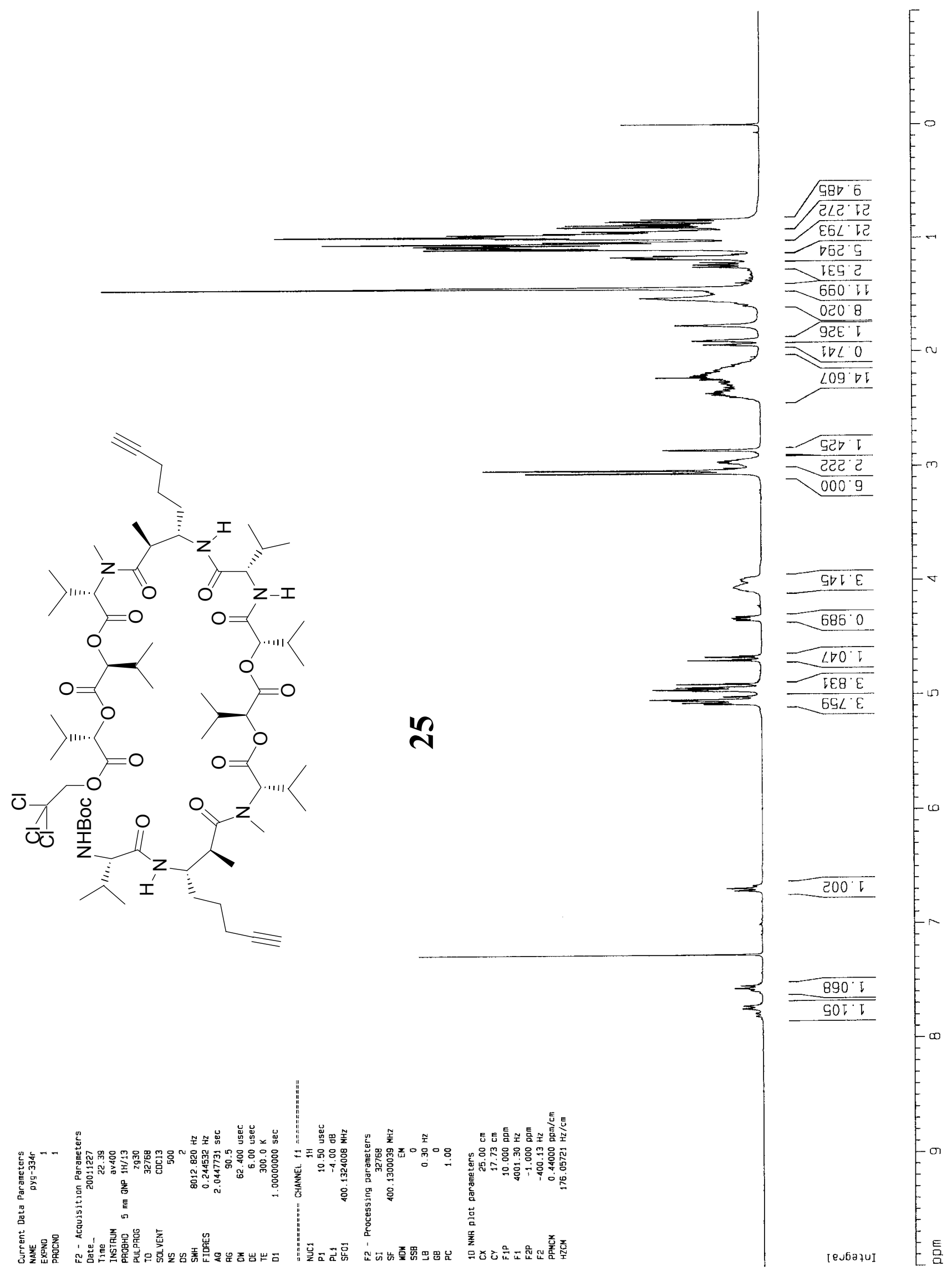




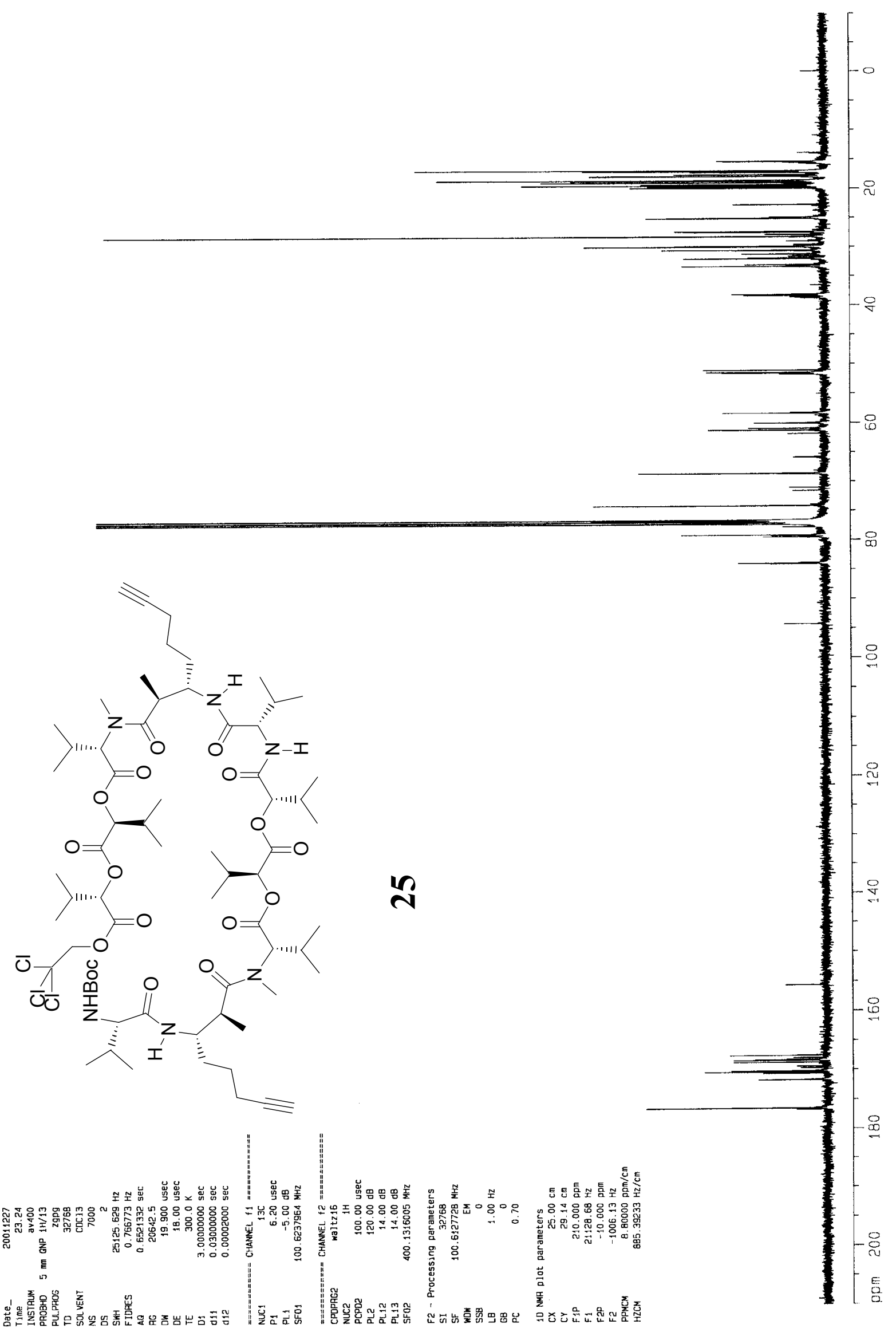




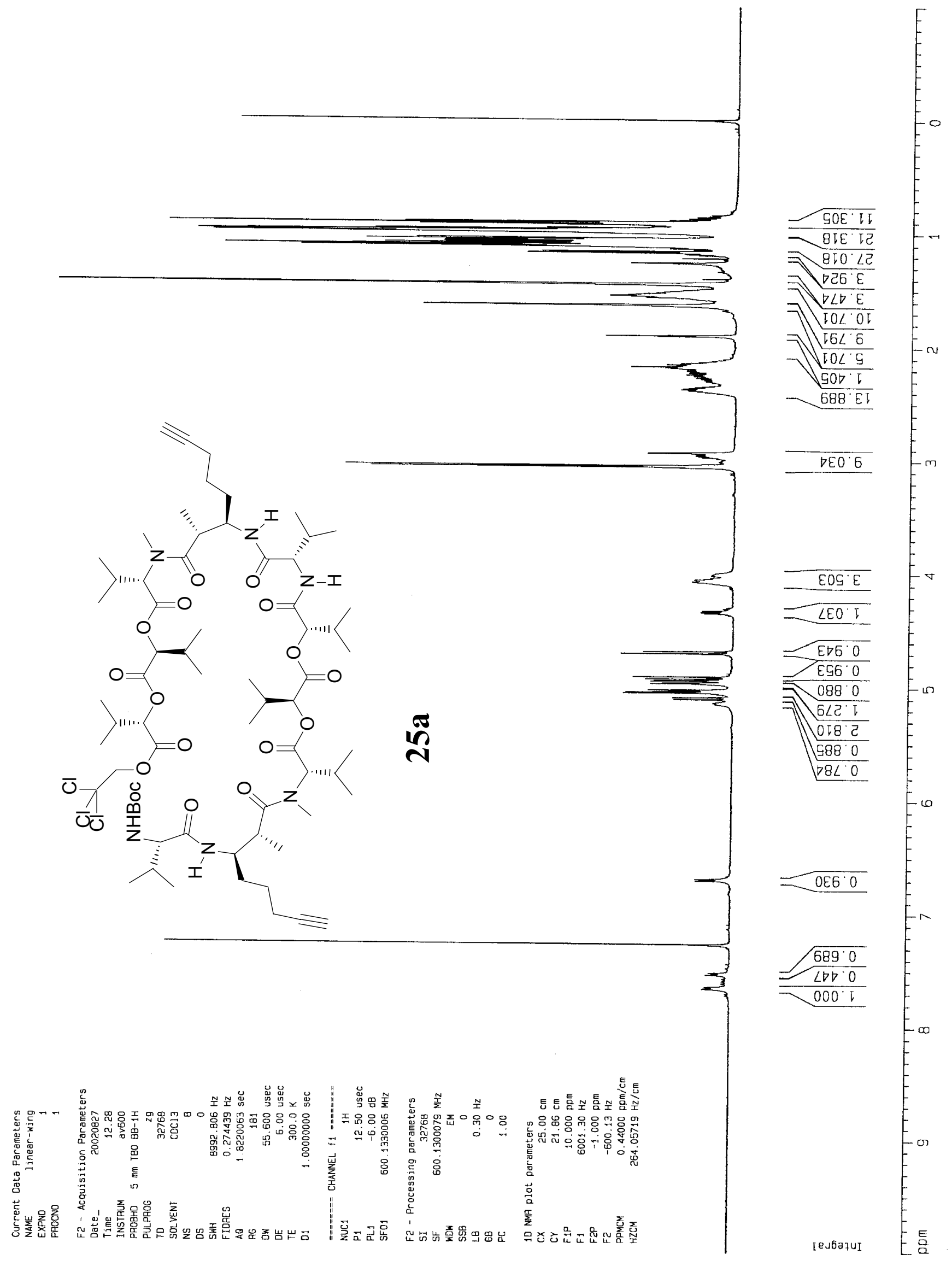




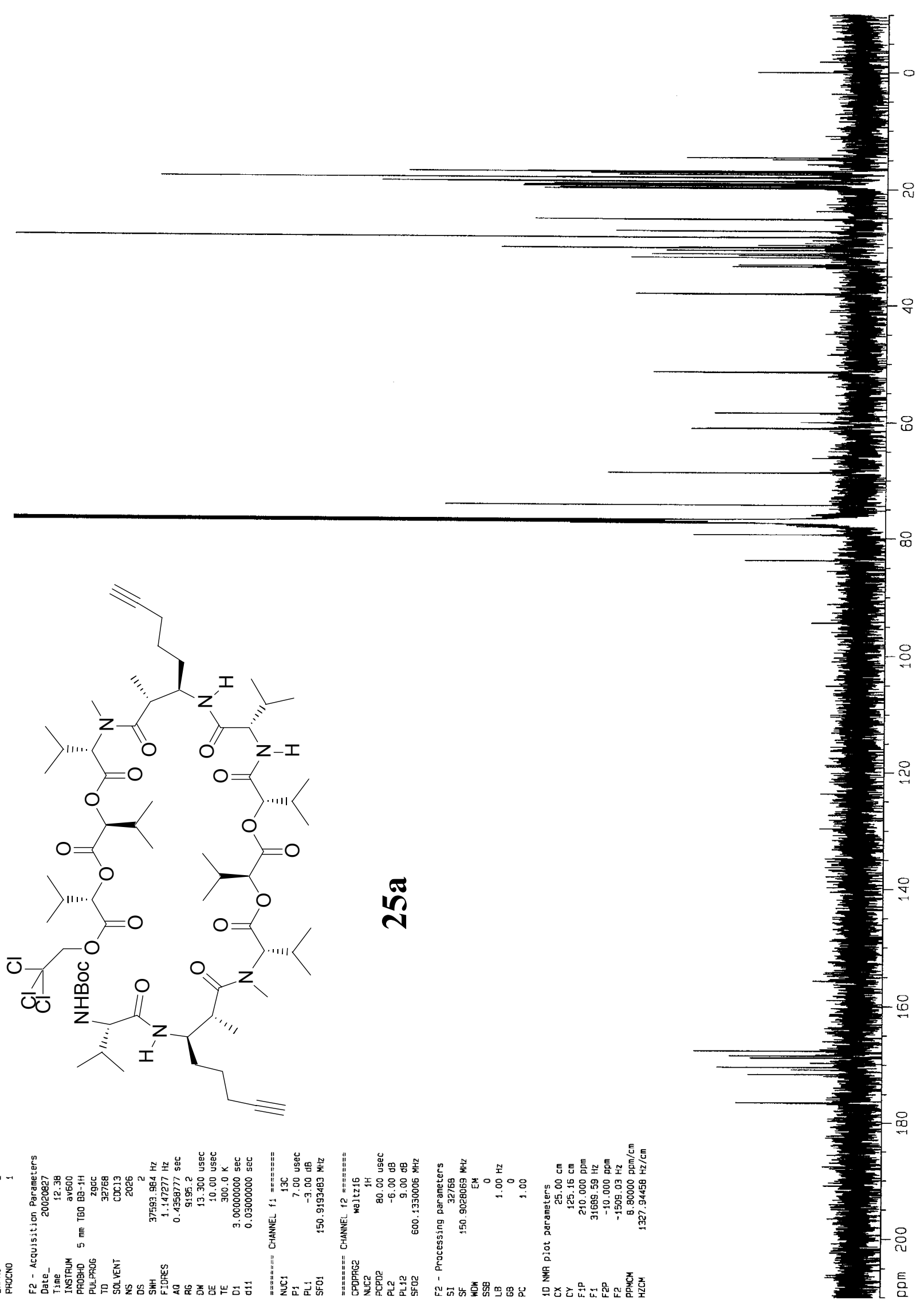

